\title{
Kernos
}

Revue internationale et pluridisciplinaire de religion grecque antique

29 | 2016

Varia

\section{The Mysteries of the Goddess of Marmarini}

Robert Parker and Scott Scullion

OpenEdition

Journals

\section{Electronic version}

URL: http://journals.openedition.org/kernos/2399

DOI: 10.4000/kernos.2399

ISSN: 2034-7871

\section{Publisher}

Centre international d'étude de la religion grecque antique

\section{Printed version}

Date of publication: 1 October 2016

Number of pages: 209-266

ISSN: 0776-3824

Electronic reference

Robert Parker and Scott Scullion, "The Mysteries of the Goddess of Marmarini », Kernos [Online], 29 |

2016, Online since 01 October 2019, connection on 10 December 2020. URL : http://

journals.openedition.org/kernos/2399; DOI : https://doi.org/10.4000/kernos.2399

This text was automatically generated on 10 December 2020 .

Kernos 


\title{
The Mysteries of the Goddess of Marmarini
}

\author{
Robert Parker and Scott Scullion
}

For help and advice of various kinds we are very grateful to Jim Adams, Sebastian Brock, Mat Carbon, Jim Coulton, Emily Kearns, Sofia Kravaritou, Judith McKenzie, Philomen Probert, Maria Stamatopoulou, and Andreas Willi, and for encouragement to publish in Kernos Vinciane Pirenne-Delforge.

\section{Introduction}

1 The interest for students of Greek religion of the large opisthographic stele published by J.C. Decourt and A. Tziafalias, with commendable speed, in the last issue of Kernos can scarcely be over-estimated. ${ }^{1}$ It is datable on palaeographic grounds to the second century BC, perhaps the first half rather than the second, ${ }^{2}$ and records in detail the rituals and rules governing the sanctuary of a goddess whose name, we believe, is never

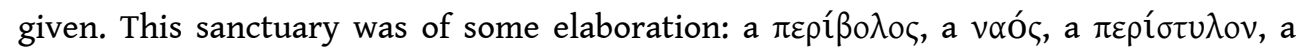

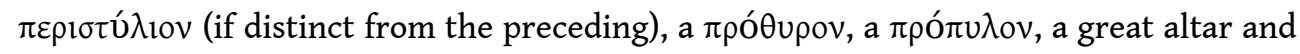
other altars are mentioned, ${ }^{3}$ though the size and precise character of these features is unknowable. The first twenty one lines of side A are lost. The legible portion begins with day-by-day regulations for a festival called here the Eloulaia (Aloulaia on side B), spread over the $12^{\text {th }}$ to $19^{\text {th }}$ of a month not here named. Side A continues with

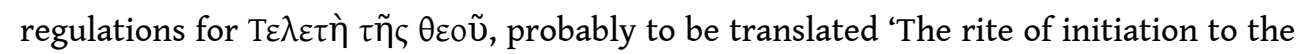
goddess'. ${ }^{4}$ Subsequent lines certainly speak of an initiation, which involved (for males only?) shaving the head. There follows a badly damaged section of uncertain content.

2 The better preserved side B is no longer calendrical in form. It begins 'An uninitiated

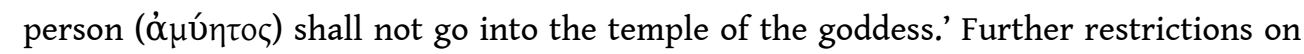
the uninitiated follow, and prescriptions for purifications in the event of violation. The central theme of what follows is that of varieties of sacrifice and other rituals required or permissible in the sanctuary - ten different possibilities are introduced with the formula 'if anyone wishes to' do X, or a variant - but other topics intrude without 
obvious coherence: regulations for 'collecting' before a festival (probably the E/ Aloulaia of side A), purity regulations for women, rules for participation in the procession at two festivals, the E/Aloulaia and the Nisanaia. At the end come further rules for purifying the shrine in the event of various polluting acts.

3 The sequence of sides assumed above is the one cautiously assumed by the editors, and must be correct. $\mathrm{B}$ begins in mediis rebus, but a text of this importance cannot have lacked a preamble. Side B could only precede side A if a whole further stele had gone before, and that would imply, very implausibly, a text of more than 300 lines in all. Side A presumably began with a prescript identifying the issuing authority; it will also have named the, to us, anonymous 'goddess' of the text - unless her name was veiled in mystic silence, or just too obvious to need specification. B 7-10, 'An uninitiated person shall not go into the $\pi \rho o ́ \theta u \rho o v$, unless any wishes to perform a vow ... and keeps pure for the three days from all the things specified above', must refer back either to side A or to nothing, since no such rule appears on $B .^{5}$ Such a general introductory entry requirement to 'keep pure for three days' from certain things would be well in place there. What else was lost on side A is problematic. The editors suppose that, after the excursus on the 'Initiation of the Goddess', a day-by-day listing of rites within the same month resumed, but Carbon has questioned whether the traces of dates that they detect are reliable; ${ }^{6}$ and certainly it would seem more likely that the other major festival mentioned later in the text, the Nisanaia, should be treated somewhere than that the rites of E/Aloulaia, already spread over eight to ten days, ${ }^{7}$ should continue further. There is another back reference in B 79 to 'the purification of the peristyle prescribed before'. No purification identified as 'of the peristyle' occurs in the surviving text, but detailed regulations for purifications of particular places are found on B and such a rule would fit less well in A; perhaps then the reference is loosely to the purification of 'the altars' at B $29-35 .{ }^{8}$

4 Linguistically the text is a blend of the familiar jargon of Greek ritual prescriptions, fluently handled in a koine only slightly tinged with Thessalian, ${ }^{9}$ with occasional bizarre forms and constructions. Some incoherence in arrangement and inconsistency in phrasing cannot be denied, though one must always consider whether what looks careless or amateur may have a reason. The sanctuary the text derives from is unknown, but the editors make a case for a location not far from the find spot, some 15 kilometres north east of Larisa. ${ }^{10}$ The text itself confirms that the setting is rural: collections are to be made 'at the threshing floors' (B 17).

5 J.M. Carbon has already significantly advanced our understanding of the text. ${ }^{11}$ Building on the editors' comparison of the festival names Eloulaia and Nisanaia with the month names Elul and Nisan found in the 'standard Mesopotamian calendar', and connecting passages in sides A and B which they left unassociated, he shows how the E/Aloulaia in all probability fell in the Thessalian month Itonios (September-October) which on independent grounds can be shown to correspond calendrically to the Semitic month Elul. Since that argument puts the Eloulaia in the Thessalian equivalent to Elul, it is a reasonable conjecture that the other festival mentioned, the Nisanaia, ${ }^{12}$ fell in the Thessalian equivalent to Nisan, Aphrios (April/May). A god Adara briefly mentioned (B 80) also bears a name connected with the Semitic month name Adar (March/April): ${ }^{13}$ some activity in that month too can perhaps be postulated. After this re-construction of the Thessalian cult's ritual year, Carbon goes on to draw attention to a private society of Alouliastai on Cos, hitherto hidden from view by a 'correction' to Anoubiastai; ${ }^{14}$ he 
also emphasizes, more firmly even than the first editors, the hybrid, multi-cultural character of the new Thessalian society (expressed, he suggests, by the use of koine at a date when most Thessalian inscriptions were still written in dialect).

6 A text as rich and important as this, as the editors and Carbon stress alike, requires further elucidation by many hands. We offer some here as students of Greek religion; with Carbon, we must hope for contributions by Semiticists, as also that technology may shed light on dark places in side A. As a preliminary we provide an English translation.

\section{Translation}

7 We translate the editors' text, as modified by Carbon ${ }^{15}$ in A 15. We print some letters in bold to indicate topics. The text is punctuated by dicolons between words (here marked :), more frequent on side A than side B, and paragraphoi in the left margin; the latter are now visible only on side B but have probably been lost from A through damage to the stone. ${ }^{16}$ Some paragraphoi follow a sense break at the end of the preceding line and are here marked //; others follow a sense break that occurs during the preceding line and are here marked /.

\section{Side A}

21 lines missing

(1) of the sacrifices first -------on the fifth

(3) ----- of the Eloulaia: on the twelfth, make preliminary sacrifice to Moira, not only collectively but also, any of the initiated who wishes to do so, privately:

(4) on the thirteenth, let the sacred places around/of the goddess be washed, ${ }^{17}$ the temple and the peristyle and the door panels ${ }^{18}$ and the propylon, and (let) a sacrifice to Mogga (be performed), and let the impurities in the sanctuary be purified by, along with the priestess, the female purification officials (phoibatriai) and the temple warden (neokoros) and any other of the initiated who wishes:

(8) on the fourteenth, adorn the goddess and the altar, sacrifice finally to Helios:

(9) on the fifteenth, let anyone who wishes and wants to sacrifice to Pan whom Syrians call [...]PLEN and put on the table whatever he wishes except fish and doves, and let the one performing the sacrifice put on the table whatever he wants and take in return from what has been put on the table. Fill the chytra with water at the night ceremony (?) from a spring: ${ }^{19}$

(14) on the sixteenth, open the chytra and, anyone who wishes, sacrifice to Moira:

(15) on the day after the procession, sacrifice to Alaia and throw (deposit?): ${ }^{20}$

(16) on the nineteenth, throw (deposit?) for Lillaias and Artemis Phylake and Apollo Pylaios (?) whatever you wish and eat everything and ... a table ... to the goddess whatever you have:

(18) Initiation to the goddess. [ ] is initiated, tend (the goddess) for three days, on the third be shaved. But if any of the unpurified wishes to be initiated, let him shave within three days, taking wine ... and let him diaklainein his mouth, the pure one of the goddess by means of the gold and the plant, but let the impure one being initiated diaklainein his mouth by the [body? blood?] ${ }^{21}$ of a bird and let the female purification officials (?) consume (?) it ${ }^{22} . .$. (23) Let him who is being initiated not sacrifice (?) but let him bring 
an Attic choinix of lagana and two kotylai of wine from the..${ }^{23}$ collect on the third day ... he will shave all round, and sacrifice to Moira a cock and ...because of the collection, whatever he gets. And let him pay to the goddess for the schoinos ${ }^{24}$ before shaving three obols. But if he does not (?) shave, an obol for the propitiatory offering. ${ }^{25}$ Let him ... in three ... let him bring also ... to the schoinos. (28) If also the person wishing to tend ... by the goddess, let him tend ... if he is well and ... and the loaf:

(30) As for the bowl, if anyone lifts the first one ... a sheep ... male or female ... homorai, four choinikes of lagana, two choes of wine, into the hands an Aiginetan [mna?], chosen things (?) as at the table-filling, but take away the leg raw ... for the priestess, and consume it there and of the others as many of the uninitiated ... and charcoal for the priestess:

(35) For the one who lifts the second bowl, a choinix of lagana, (two?) choinikes of homora, ${ }^{26}$ a kotyle of olive oil into the hands, a stater into the collecting-box (?), ${ }^{27}$ two choes. Increase these in the same way: as from the first (bowl) ... wherever he wishes of those initiated. Sprinkle with salt

Thereafter scattered words only. The following notabilia are read by the editors: 44, 'on the twentieth', 47, 'on the twenty sixth' (but note the doubts of Carbon); ${ }^{28} 41-2$, 'Aphrodite'; 42 and 47, 'basket'; 44, 'throw'; 45, 'be slaughtered'; 48 and 53, 'swear' ('after washing' in the latter); 51-2, 'if of the uninitiated ... the altar'; 52, 'let him pay an Aiginetan drachma'.

\section{Side B}

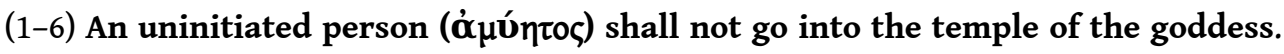
If any goes in, purify with a hen and sacrifice in accompaniment another full-grown fowl on the altar of Moira, and the priestess or the neokoros or one of those who lift ${ }^{29}$ the sacred objects shall do the purification, and (the offender) shall bring two choinikes of loaves, eight kotylai of wine for the mixing-bowl. //

(7-12) An uninitiated person shall not go into the prothyron, unless any wishes to perform a vow and to keep the sacred things pure (?), ${ }^{30}$ and keeps pure for the three days from all the things specified above. He shall bring in accompaniment to the vows half a kotyle of oil for the lamp, an obol, torches, incense, a libation.//

(13-16) If any of the uninitiated enters the prothyron, purify with a cock or hen, sacrifice in accompaniment a leg of whatever he pleases, except of pork, and (bring?) three Attic choinikes of lagana and half a chous of wine.//

(17-21) Collect on the new moon of the month Itonios to the threshing floors, but do not collect (going) into a house nor take the sacred objects in, unless three days in advance [Interlinear addition Collect on the tenth until the twelfth of (the) month] one announces it. ${ }^{31}$ If any of the female purification officials does not do this, let her pay to the sanctuary a lamb and the accompaniments for this sacrifice. ${ }^{32} / /$

(22-23) Inscription for the peristyle. Pre-sacrifice first to Phylake and to Men as offerings incense. ${ }^{33} / /$

(24-26) If anyone as an offering wishes to sacrifice white fowl, let him sacrifice males to Men, female to Artemis, and if he wants (to sacrifice) lambs, similarly.

(26-35) A woman shall enter from childbirth on the thirtieth day, she who aborts on the fortieth day, from a man after washing from the head down, from the processes of nature (i.e. menstruation) on the seventh day. If anyone enters without having observed purity ( $\dot{\alpha} \gamma v \varepsilon \dot{\sigma} \sigma \alpha$, masculine) ${ }^{34}$ from the things aforementioned, let him purify the altars 
with a chicken, and let him sacrifice in accompaniment on the altar of Phylake a hen or a roasting fish, a mna of whatever meat he wishes except pork, and (bring?) a choinix of lagana and into the mixing-bowl four kotylai of wine. The neokoros shall perform this purification and any of the female purification officials who is present:

(35-43) If anyone wishes to sacrifice to the goddess by the Greek rite, it is permitted (to sacrifice) whatever he likes except pig. To accompany the sacrifice, one must bring to the table as the deposited offerings a choinix of lagana, a choinix of homora, and three obols for the collecting-box and a kotyle of olive-oil for the lamp and for the mixing-bowl a kotyle of wine from the sanctuary, ${ }^{35}$ for the table the breast boiled and the leg raw. Bring the entrails to the priestess, the liver and lungs and diaphragm and left kidney and tongue. The right kidney and right akrokolion ${ }^{36}$ and heart and omentum and the front leg (? $)^{37}$ and the portion of the tail customary for sacred offerings onto the fire. ${ }^{38}$

(44-45) After doing this and completing this sacrifice, let him bring another victim of whatever species he pleases and let anyone who pleases eat of it: / (?)

(45-49) If anyone wishes to make a complete 'full table' for the goddess, (let him bring) a full grown sheep, male or female, and let it (the full table) extend to include (?) two choinikes of homora, four choinikes of lagana, two choes of wine, a drachma for the collecting-box, a kotyle of olive-oil for the lamp, and an uninitiated person does not taste of these: /

(49-51) If anyone wishes to perform an all-day rite for the goddess, (let him do so) bringing himself a lunch of whatever he wishes, except pork, and for the lamp a halfkotyle of olive-oil. ${ }^{39} / /$

(52-53) To the ear of the goddess and her hair, burn ${ }^{40}$ incense, myrrh, aromatic plants, rose essence, (bring) three obols for the collecting-box. //

(54-57) If anyone sacrifices a fowl or a goose, (pay) for the fowl (female) into the collecting-box an obol, for the goose an obol and a half, (put) the legs and the innards onto the table, but let him carry away the rest wherever he wishes. Let him also bring four kotylai of wine, a choinix of lagana, half a kotyle of olive-oil. //

(58-61) If anyone wishes to sacrifice a bovine, bring to the table three choinikes of lagana, a choinix of homora, two choes of wine, two kotylai of olive-oil, sufficient wood, a gold piece for the collecting-box, and remove the sacred parts as from the sheep. /

(61-65) All those who wish to sacrifice at the Nisanaia or the Aloulaia, bring the animal to the procession. Let the procession occur at the Nisanaia on the next day if the goddess comes from the river, at the Aloulaia on the seventeenth in the morning. At night perform a torch-ritual. Anyone who wishes shall process, having washed from the head downwards on the day itself, and may go in as far as the sanctuary of Phylake.//

(66-70) If anyone wishes to burn whole a full-grown ram, or, if not, a male lamb, for the full-grown animal a stater into the collecting-box, for the lamb an Aeginetan (drachma), sufficient firewood in addition to this, a chous of wine into the mixing-bowl, on the table a choinix of lagana, a choinix of homora, 'basasibarouta, ${ }^{, 41}$ incense, myrrh, a kotyle of olive-oil for the lamp: /

(70-73) If anyone wishes to burn whole a goose, into the collecting-box two obols, sufficient firewood, a torch, four kotylai of wine into the mixing-bowl, a half kotyle of olive-oil for the lamp, 'basasibarouta', incense, myrrh.

(73-74) If anyone wishes to burn whole a trubba ${ }^{42}$ or a quail, an obol and a half into the collecting-box, the rest the same as for the goose. 
(74-80) An uninitiated person may not approach the great altar, nor sacrifice a hen on it ${ }^{43}$, nor bring the egg of another species (literally, 'another egg'). If anyone ${ }^{44}$ sacrifices a hen to the goddess, (let it be) at the altar of Moira, and let anyone who wishes go to the altar of Moira and Helios ${ }^{45}$ If any uninitiated person goes to the great altar, let him purify it according to the purification described previously for the peristyle ${ }^{46}$ Likewise let them keep away from the altar of Adara and Lilla.

(80-82) If anyone kindles fire, let him purify according to the notice on the peribolos wall. ${ }^{47}$ If anyone urinates or bleeds within the peristyle, let him purify with the purification previously described.

\section{Gods}

9 The gods of the law are well discussed by the editors. Of the non-Greek gods, only Men is attested elsewhere. Adara, as we have seen, bears a relation to a Semitic month name; Mogga (A 6), Alaia (A 15), and Lilla/Lillaias (A 16, B 80) are unknown. ${ }^{48}$ Noteworthy is 'Pan whom the Syrians call [...] PLEN', a perhaps unique instance in a Greek sacred law of an interpretatio graeca that announces itself as such. On one crucial point we differ from the editors. ${ }^{49}$ Whereas they identify the unnamed 'goddess' of the text with Artemis Phylake, we believe that Artemis Phylake is a distinct figure with a precinct of her own on the fringes of the main sanctuary; the goddess herself is always anonymous in the surviving text, but, honorand as she is of Nisanaia and Aloulaia, would surely not have borne a Greek name.

10 The full Greekness of one bearer of a Greek name can also be doubted. Moira is mentioned six times in the singular as recipient of various types of sacrifice; she shares an altar with Helios (only occasionally an object of cult in Greece) as well as having one of her own, ${ }^{50}$ unless these two altars are the same. She has a particularly close relation to 'the goddess': uninitiated persons wishing to sacrifice a fowl 'to the goddess' are, remarkably, diverted from her altar and directed instead to that of Moira (B 76-77). Outside this text, though the role of Moira as fate or death is familiar in poetry and thought, a singular Moira is not attested in cult at all, let alone with such prominence..$^{51}$ The Moirai Patroiai known from Pherai ${ }^{52}$ provide another Thessalian instance of Moira, but still only in the familiar group form. To interpret the unique singular use, there seem to be two possibilities. One might postulate creative theology within the context of mysteries, ${ }^{53}$ an attempt somehow to find a way of gaining control over Fate through ritual. But it is perhaps more likely that a non-Greek figure underlies her too, like 'Pan whom the Syrians call [...] PLEN'. An obvious possibility would be $\mathrm{Gad},{ }^{54}$ even if the equivalent often found later for this power is not Moira but Tyche.

\section{The Sanctuary}

11 The many architectural features mentioned in the text invite an attempt at visualisation. It speaks of $\pi \varepsilon p i ́ \beta o \lambda o \varsigma, ~ v \alpha o ́ \varsigma, \pi \varepsilon \rho i ́ \sigma \tau u \lambda o v, \pi \varepsilon \rho ı \tau u ́ \lambda ı v, \pi \rho o ́ \theta u \rho o v$,

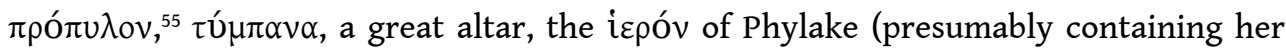
altar), the altar of Moira, the altar of Moira and Helios, the altar of Adara and Lilla; there are presumably also altars of Men, Pan, Helios and possibly other gods mentioned as recipients of sacrifice..$^{56}$ Unfortunately, the imprecision with which Greeks used architectural expressions, which for them derived from words used in ordinary speech 
and were not technical terms, leaves crucial issues ambiguous. We cannot decide from vocabulary alone whether $\pi \varepsilon \rho i ́ \sigma \tau u \lambda o v$ was distinct from $\pi \varepsilon \rho \iota \sigma \tau \hat{\nu} \lambda_{1 o v}$ or $\pi \rho o ́ \theta v \rho o v$ from

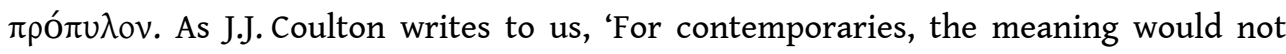
depend on the vocabulary, but on what they saw.'

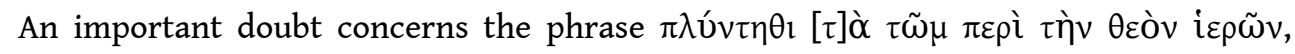

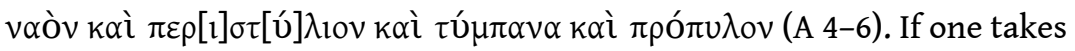

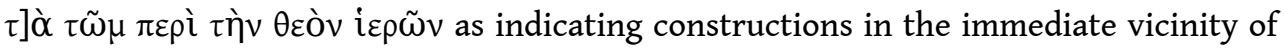
the goddess's cult statue, as the voó $\zeta$ at least certainly was, it will become likely that the other items mentioned were part of the temple: the voó

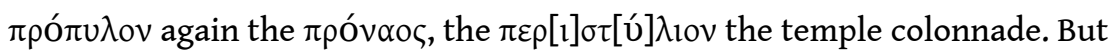

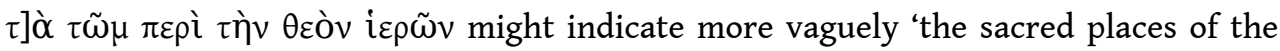
goddess', since in the Koine 'the use of bare case-forms yielded increasingly to prepositional phrases', and in this instance the use of the preposition would have avoided a 'nested genitive'. ${ }^{57}$ On that view the items listed for cleaning would be the architecturally finest elements most deserving this treatment; one notes the absence of the great altar, but 'bloodying the altar' was a ritual act and it is not clear that cleaning altars was normal ${ }^{58}$.

Three points appear certain: the sanctuary of Phylake is at some remove from the voó $\varsigma$ of the goddess, since at the great festivals of the cult anyone who wishes, i.e. the uninitiated, may process up to (but presumably not beyond) this landmark (B 65).

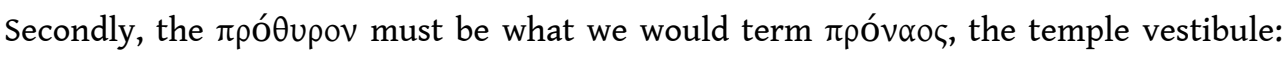
this emerges from the juxtaposition at B 1-16, where non-initiates are barred first,

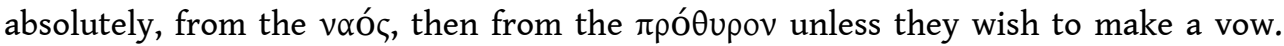

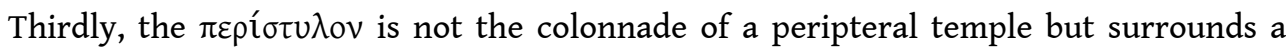
larger open area. B 81-82 prescribes a purification 'if anyone urinates or bleeds within the peristyle'. While urination and indeed excretion within sacred space certainly occurred, ${ }^{59}$ the area most exposed to such desecration was surely the broader precinct, not the temple itself; and it would have been bizarre to impose a sanction on such behaviour merely within the temple, implicitly condoning it within the rest of the sacred area. One can perhaps go on to infer that a peristyle thus enclosing an appreciable area is unlikely to have been referred to by the diminutive $\pi \varepsilon \rho ı \tau$ vi $\lambda_{1} \circ$; the two things will therefore have been separate.

A possible model for the sanctuary thus becomes 'a peripteral temple including a surrounding colonnade (peristylion) and a pronaos (prothyron), with a large altar of the goddess before it and a number of minor altars to other deities scattered around, all enclosed in a (probably rectangular) peristyle court (peristylon) with a formal entrance (propylon). The whole area would then be the peribolos' (J.J. Coulton). But a $\pi \varepsilon p 1 \sigma \tau \hat{\imath} \lambda(\imath) o v$

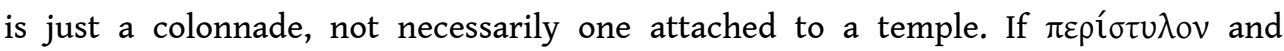
$\pi \varepsilon \rho[1] \sigma \tau[u ́] \lambda_{10} v$ are distinct, one could envisage two colonnaded courts, either nested in Russian doll style or one leading into another. As a result of these various uncertainties it is impossible to determine to what extent the sanctuary was of familiar Greek form. Nothing contradicts that assumption; but, even if the arrangement differed from Greek norms as far, say, as that of some of the sanctuaries of non-Greek gods on Delos, the vocabulary used to describe it would not necessarily reveal the divergences. The question of how exotic a man from Larisa who had never left Thessaly might have found the sanctuary is therefore regrettably unanswerable. 
What the bare text does give us, unusually, is some detail on the division between places open to all and those confined to initiates. Non-initiates are excluded from the

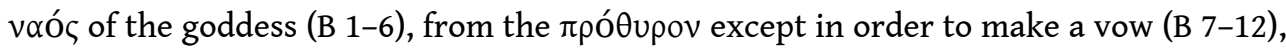
from the great altar (B 74-79), from the altars of Adara and Lilla (B 79-80). (It may not be coincidence that the 'reserved' altars [of 'the goddess', Adara and Lilla] belong to deities with non-Greek names.) The restrictions on non-initiates' access to the voó $\pi \rho O ́ \theta u \rho o v$ no doubt explain why they may not participate in the general cleansing of the sanctuary prior to the E/Aloulaia (A 4-8). Since non-initiates have to be explicitly excluded from particular buildings and altars, prima facie they may enter the rest of the sanctuary, in certain circumstances at least. Whether non-initiates could always enter most of the sanctuary, or only on particular occasions, is harder to determine. In B 61-65 it is specified that at the two great festivals 'anyone who wishes' (non-initiates presumably included) may process as far as the sanctuary of Phylake. In itself that rule might imply that for the rest of the year non-initiates could not come so far; it would be a relaxation on the occasion of the festivals. But this rule can equally well be interpreted as a tightening in a particular context: on this occasion of special sanctity (and perhaps unusual crowding) non-initiates are debarred further out than usual. At B 77 'anyone who wishes' (who on our view is a non-initiate) is allowed to 'proceed to the altar of Moira and Helios' when a sacrifice is made there. Again, 'to sacrifice, but not in other circumstances' would be a possible understanding. But this rule has been immediately preceded by an explicit ban on non-initiates approaching the 'great altar', and the point may rather be to underline that access to the altar of Moira and Helios is, by contrast, free. What is clear at all events is that the arrangement is not one of inner and outer zones, with non-initiates permanently stopped at the transition between the two. ${ }^{60}$

\section{Near Eastern Ritual Influences}

Before looking in detail at the various ritual procedures in the inscription, it may be useful to consider against possible Near Eastern backgrounds some prominent ritual elements in it that are unexpected from a Greek point of view but may be explained on the basis of hybridity.

\section{Bird Sacrifice}

Sacrifice of birds and their use in purification are frequent in the inscription, and one regulation may suggest that a hen was a standard offering to the goddess on her "great

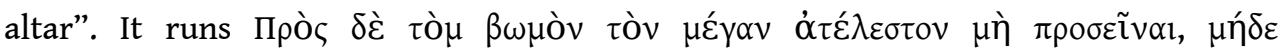

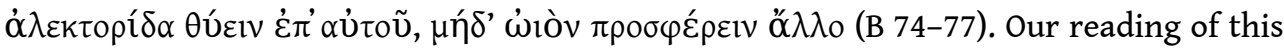
passage differs from that of the editors, who think that on the one hand it bans uninitiated persons from the great altar and on the other forbids anyone from sacrificing hens on it. On that reading, however, the regulation prohibits everyone, including initiates, from sacrificing hens to the goddess on her own altar, and this despite the fact that pigs alone are prohibited as victims for her at B 36 and provision is made for sacrifice of a female bird, which very probably means a chicken, at B $54-$ not explicitly for the goddess, but it would be surprising if it were a suitable offering to any divinity but her. It is therefore preferable, and equally plausible linguistically, to take 
$\dot{\alpha} \tau \varepsilon ́ \lambda \varepsilon \sigma \tau o v$ as the subject of all three imperatival infinitives and render "An uninitiated person may not approach the great altar, nor sacrifice a hen on it, nor bring an egg of another species". This coheres well with the sequel, which we take as a new sentence: ${ }^{61}$

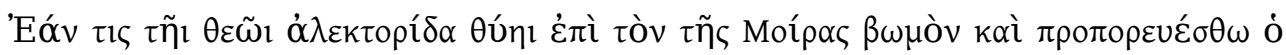

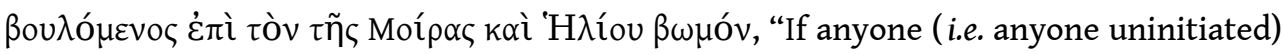
sacrifices a hen to the goddess, (let it be) on the altar of Moira, ${ }^{62}$ and anyone who wishes can proceed as far as the altar of Moira and Helios". Such a formulation makes sense if initiates commonly sacrificed hens to the goddess on the great altar and the uninitiated are therefore permitted to make the same offering, but on Moira's altar. An offering for one divinity on another's altar - for which no parallel occurs to us - is very surprising. It can perhaps be understood as another reflection of the remarkable combination in these regulations of concern not only to exclude but also to include the uninitiated, or it may have to do with the nature of this remarkable, singular Moira (see above, p. 217-218). On the basis of this interpretation of the passage we include hen and egg offerings to the goddess in this summary of birds in the inscription:

Purification (?) in the context of initiation to the goddess: ópvis (A 22-23).

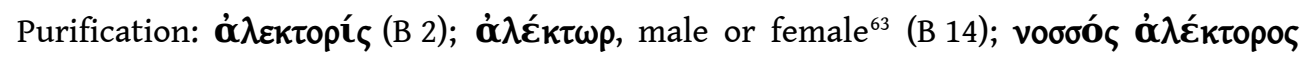
(B 30-31).

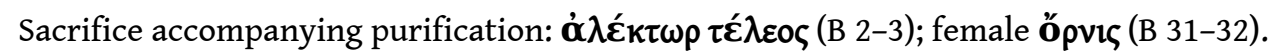

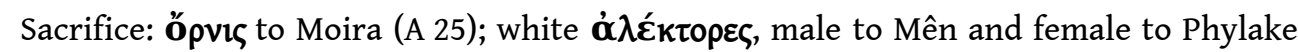

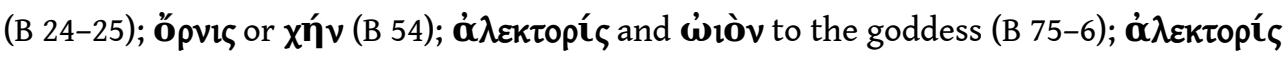
on the altar of Moira (B 76-77).

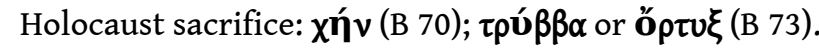

It seems probable, in accord with standard Greek usage,$^{64}$ that ôpviৎ as well as $\dot{\alpha} \lambda \dot{\varepsilon} \kappa \tau \omega \rho$ refers in our text primarily to the domesticated chicken, which was available at sacrificial or purificatory need as game-birds were not. Beyond the famous cock which Socrates says "we owe to Asclepius" at the end of the Phaedo, we have further evidence for the offering of cocks to the god of healing and to other gods. ${ }^{65}$ Birds are however uncommon victims in Greek sacrifice and generally regarded as a poor person's substitute for a larger animal. ${ }^{66}$

The relative valuation of victims in Semitic and Syrian tradition seems essentially the same as in Greek: bovines, ovines/caprines, and birds in that order of prestige, and usually listed in that order, as in the Hebrew Bible, the Punic "sacrificial tariffs" from Marseilles and Carthage, and Lucian's De Syria Dea; ${ }^{67}$ the Marseilles tariff explicitly exempts those "poor in cattle or birds" from fees or perquisites. In the Hebrew Bible two turtledoves (or perhaps rather two fow ${ }^{68}$ ) or two pigeons (one as a purification sacrifice, the other as a burnt offering) are allowed as a substitute "if you cannot afford a sheep", and another passage requires that a woman at the end of her post-childbirth purity exclusion bring to the priest a yearling lamb for a burnt offering and a young pigeon or turtledove/fowl for a purification offering, but "if she cannot afford a lamb she shall take two turtledoves/fowl or two young pigeons"; Mary takes advantage of the latter clause in the case of Jesus..$^{69}$ In his important recent study of Hebrew sacrifice, Naphtali Meshel suggests that a post-biblical "zoemic shift" to the use of immature animals as wholeburnt and purification offerings "may have originated from pragmatic considerations: the sacrifice of young animals is less of an economic burden, a particularly significant factor for laypersons". ${ }^{70}$ 

traditions than they are in Greek. In the Hurrian realm of southeastern Anatolia and northern Syria birds (whose species is rarely indicated) are the most frequent burnt offerings (for underworld gods). ${ }^{71}$ The Hebrew Bible provides for sacrifice of birds both as personal (rather than public) burnt offerings and as purification sacrifices in a variety of contexts, ${ }^{72}$ which normally involve one victim as purification offering and a second as burnt offering. Meshel notes that "the sacrifice of pairs of birds was apparently quite common in the Herodian temple", ${ }^{73}$ and a second-century-AD tractate in the Mishnah, Kinnim, deals entirely with "The Bird-offerings". ${ }^{74}$ Many bones of birds are found at what have been identified as Hebrew cultic sites, where O. Borowski argues that a "large quantity of birds must have been required for sacrifice" and notes evidence for very large underground columbaria at and in the vicinity of Hellenistic Maresha..$^{75}$ In Mesopotamia, whose ritual traditions provide a number of striking comparanda for our text, birds are standard offerings in the meals presented to the gods. ${ }^{76}$ So too are eggs, as in B 76 of our text: an inscription published in 1991, dated on palaeographical grounds to the time of Nebuchadnezzar II (who reigned ca. 605-562 BC) or one of his successors, attests eggs in meals presented to the gods in Babylon, confirming earlier attestations in three inscriptions of similar date of eggs (in one case duck eggs), fish, and birds, collectively presented as "the pride of the marsh", and there is also evidence from Seleucid Uruk for birds and ostrich and duck eggs presented as part of divine meals for Anu, Antu and other gods. ${ }^{77}$ Cultic texts from Ugarit too attest many offerings of birds. ${ }^{78}$ At Palmyra, a sarcophagus of the first half of the third century $\mathrm{AD}$ with a type-scene of sacrificial ritual depicts libations and fruit offerings and only two animal victims, a young bull and a plump fowl..$^{79}$ The Punic sacrificial tariffs mentioned above include birds as victims, and Eudoxus of Cnidus attests Phoenician sacrifice of quail (mentioned at B 73 in our text) for Herakles of Tyre (Melqart). ${ }^{80}$ Of the cultic practices of Seleucid Harran in upper Mesopotamia (Roman Carrhae) we hear that "Most of their sacrificial victims are cocks. The offering is not eaten but burned". ${ }^{81}$ Birds were also used by the Hittites in purification rituals resembling the purifying of lepers in the Hebrew Bible. ${ }^{82}$

Chickens, and in particular cocks, occur very frequently in the iconography - reliefs, statuary, and coins - of the Anatolian god Mên, who also receives cult in the goddess's sanctuary at Marmarini..$^{83}$ Some literary sources apparently testify that the white cock was specially sacred to Mên, but this may merely be the result of confusion in the testimonia between the god's name and the nouns $\mu \eta$ n, "month" and $\mu \eta$ v $v$, "moon". ${ }^{84}$

No doubt the prominence of birds at Marmarini, both as sacrificial offerings and as purifying agents, reflects this Near Eastern background.

\section{Holocaust Sacrifice}

The elaborate set of provisions for elective holocaust sacrifice of various victims (ram or lamb, goose, trubba-bird or quail) toward the end of the inscription (B 66-74) is without parallel in our evidence for Greek sacrifice, where holocausts tend to be prescribed on particular occasions and are relatively uncommon. Though the text says nothing about the grounds on which anyone might "wish to wholeburn" any of these victims, it suggests that such offerings were routine, and this too is probably best explained as a reflection of Near Eastern sacrificial practice. 
Mesopotamian sacrifice was "neither the slaughter of animals nor the process of consumption. Rather, they usually focus on presentation", 96 that is of meals to the gods. Holocaust is, however, a well-attested sacrificial mode in the Hittite/Hurrian realm, especially in north Syria and southern Anatolia, under the Hurrian term ambašši derived from the verb am- "burn (up)"; performed on a hearth, ambašši-sacrifices most often involved birds and lambs as victims..$^{97}$ It was presumably this tradition in the north and/or common Semitic tradition from the south that affected sacrificial practice in the Syrian region, where we have, for example, burnt-offering (šrp, from the root "to burn") in Ugarit and clear evidence for holocaust sacrifice in Palmyra, both under the Palmyrene term mqlwt' and in texts composed in Greek. ${ }^{98}$ One Greek

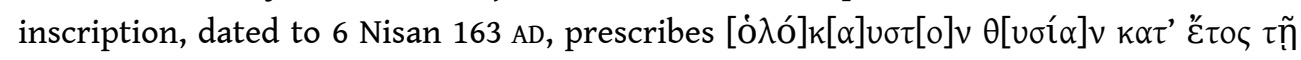

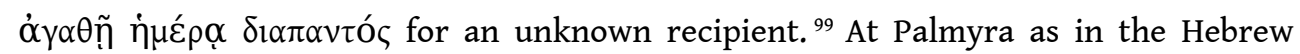


evidence incense figures prominently in sacrificial ritual, ${ }^{100}$ and we also have the testimony of Herodotus that a thousand talents of incense a year is burnt for Baal in Babylon, and of Lucian that the "ambrosial odour" of incense strikes one from a distance as one approaches the sanctuary of the goddess and that one's garments retain the scent of it when one leaves and one remembers it forever. ${ }^{101}$

\section{Table Offerings}

We have mentioned that presentation of meals to the gods or "table offerings" are the commonest form of Mesopotamian sacrifice, and such offerings play a prominent role in cultic practice at Marmarini. We discuss below, for example, the previously unattested rite of $\tau \rho \alpha \pi \varepsilon \zeta o \pi \lambda \eta \sigma i \alpha$ or "table-filling", which finds its closest parallel in the rite described by the phrase "to fill a table for the god" in the second-century AD cult of Mên Tyrannos at Sounion in Attica. The originally Anatolian Mên is a recipient of cult also at Marmarini, and tables of offering are prominent in both our visual and textual evidence for his cult, especially on reliefs (all of which also include depictions of cocks) from Athens and from Thorikos, which lies just north of Sounion on the east coast of Attica. ${ }^{102}$

\section{Tendance of Images}

The new inscription involves a number of rites that seem to be focused on a statue of

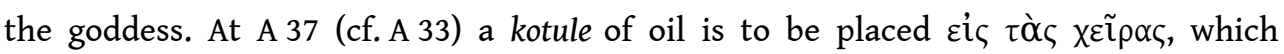
presumably means the hands of the statue of the goddess whose censing we hear about

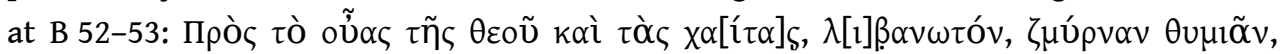

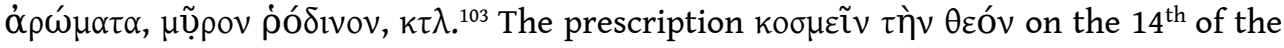
month during the festival Eloulaia (A 8) clearly refers to the goddess's image, as may

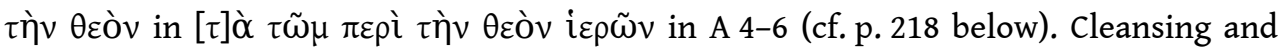
decoration of a divine image are well-attested in Greek cult, but we are unaware of any Greek parallel for the censing of the ear(s) or hair of an image of a god or goddess, and it may be that Near Eastern influence is detectable here too. Especially in Mesopotamian tradition, statues of gods play a central role in ritual. Thorkild Jacobsen discusses the elaborate ritual process by which new statues have their materiality negated and are "brought to life". ${ }^{104}$ A neo-Babylonian text of 600-500 BC describes how a new statue is taken to the side of a river, "brought to life" there, and returned thence to its temple, ${ }^{105}$ which might (or might not) be relevant to the provision in our inscription that the procession of the Nisanaia festival be held "if the goddess comes

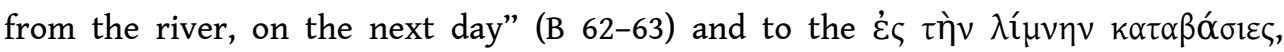
"descents to the lake" of $\tau \grave{\alpha}$ i $\rho \alpha$, "the sacred images", which Lucian describes in the cult of the Syrian goddess. ${ }^{106}$ Caution is in order, but the tendance of the divine image at Marmarini may reflect such traditions.

\section{The Mesopotamian "Washing of the Mouth" Ceremony (mīs pî)}

The process by which Mesopotamian statues of gods are "brought to life" is the ritual of mis pî or "mouth-washing", a purification ritual that occurs in a wide variety of contexts and is attested from early Sumerian sources down through Seleucid Uruk. ${ }^{107}$ 
The earliest use of the ritual seems to be for the dedication of divine images, and the mouth-washing is performed on the statue; the whole dedication ritual seems in fact to be referred to as "the mis pî", and the mouth-washing (whatever form it took on a statue) is performed fourteen times in the course of it. ${ }^{108}$ The mis pî is also used - again often repeatedly - in the initiation of priests (in combination with a shaving ritual, cf. A 19, 20, 27 in our text) ${ }^{109}$ and on the Assyrian king. ${ }^{110}$ In other contexts it is performed on animals and also on inanimate objects, ${ }^{111}$ e.g. on a bull that is sacrificed and its hide used to make the drum of a kalu-priest (who performs lamentation ritual) and then on the drum itself, ${ }^{112}$ and also e.g. on a torch in the temple of Anu in Uruk: "The mahhu-priest, wearing a sash, shall use a naphtha fire to light a large torch in which aromatics have been inserted, and which has been sprinkled with sweet oil, and upon which "washing of the mouth" has been performed". ${ }^{113}$

If this kind of rite is in the background of the cult at Marmarini - which, as we have seen, certainly has elements in common with the neo-Babylonian material - it may be relevant to the difficult passage about initiation during "the Rite of the Goddess" (A 1823), if the newly attested verb $\delta 1 \alpha \kappa \lambda \alpha i ́ v \varepsilon ı v$ in the twice-repeated phrase $\delta 1 \alpha \kappa \lambda \alpha \imath v \varepsilon \sigma \tau \omega$

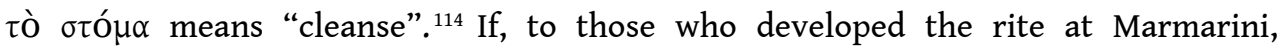
Babylonian "mouth-washing" was a familiar ritual which occurred in a variety of contexts (including initiations of priests which also involved shaving), then it could readily be transferred to non-priestly initiation and, to judge from the parallels, performed to purify an initiate himself, or a bird used in a rite of initiation. This is of course highly uncertain - in itself, the new verb could more readily be explained as a variant of $\delta 1 \alpha k \lambda \alpha$ ó $\omega$ with the factitive/causative - $\alpha i v \omega$ suffix - but given other striking parallels between the new text and Mesopotamian traditions it seems possible that the equivalence between the plausible sense "cleanse the mouth" and Mesopotamian mis p $\hat{\imath}$ is not coincidental.

\section{Initiation}

Initiation has a central place in the text, and we need to try to locate the evidence from Marmarini in relation to what else is known about the phenomenon in the Hellenistic period.

'Initiations', in the sense of rites access to which is achieved by being subject to an act of $\tau \varepsilon \lambda \varepsilon \tilde{v} v$, are broadly of two types, the second of which mutates into what should perhaps be recognised as a third. ${ }^{115}$ (We disregard here the class of maturation rites often so described in modern, but not ancient, terminology; they are irrelevant here.) Some require travel to a particular sanctuary with which they are exclusively associated: such in the classical period were the Mysteries of Eleusis and Samothrace and of the Kabeirion at Thebes, and perhaps some others from the many that are attested later. With Eleusis and Samothrace the verb $\mu v \varepsilon \tilde{v} v$ and the noun $\mu \nu \sigma \tau \eta \dot{p} 1 \alpha$ are particularly associated, but religious vocabulary could not be patented and the noun in particular came to be used more generally. ${ }^{116}$ These mysteries were celebrated in a special 'initiation-hall', and typically at one fixed point in the year (though those of Samothrace are thought to have been more flexible). One went away from such an initiation with a permanent status as initiated (though two visits might be required to reach the highest grade), and having achieved (according to the promise of the cult) a permanent benefit: a better fate in the afterlife at Eleusis, security in sea-voyages on 
Samothrace. There would be no reason to re-visit the sanctuary, though some initiates may have done so for the pleasure of the experience.

Other initiations belong to a particular god rather than a particular sanctuary, and can be administered in multiple locations wherever a qualified minister of that god is present: of such a type are the initiations (found in many places) of Dionysos, Mother, the Korybantes, probably Demeter, and those performed by the Orpheotelestai. ${ }^{117}$ The element of 'revelation' so important at Eleusis and Samothrace was not necessarily present; what mattered rather was participation in a dramatic ritual. Nor is it clear that such rites always offered lasting benefits to their initiates. Perfect passive participles implying a change of status are found in relation to the rites of Dionysus and the

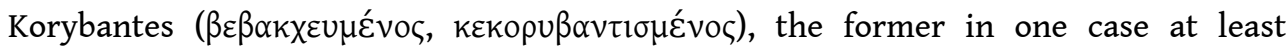
allowing access to a privileged burial plot. ${ }^{118}$ The rites of the Orpheotelestai offered release from guilt, now and after death; the Korybantic rites release from mental disturbance. But other permanent benefits promised by these initiations are uncertain. It may be that the prime reason for being initiated to Dionysus or to the Mother was to be able to participate in certain rites not once but regularly; thus the main festival of Demeter on Mykonos was open to Mykonian women by right, but to women merely resident on the island only if they had been 'initiated to Demeter'. ${ }^{119}$ On this view initiation meant entry into a cult society. But the truth is that we know very little of the initiators for (say) Dionysos and Mother attested in the inscriptions: where they initiated and how often, how permanent or otherwise were the groups of initiates they assembled.

Out of these 'wandering initiator' rites (though not from them alone) emerged cult associations with fixed membership and fixed locations; as the associations proliferate, the wandering initiators disappear. ${ }^{120}$ Some cult associations use the language of initiation, others not. Where it was used, a specific and no doubt striking ritual was probably referred to, to which life-changing powers may have been ascribed, but even in that case the longer consequence was membership of a society: initiation was not a fulfilment but a beginning. ${ }^{121}$ The members of some such societies came to be described

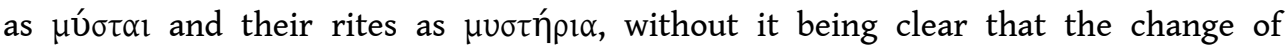
vocabulary brought with it a change of ritual. ${ }^{122} \mathrm{An}$ important and unexpected early instance is a society of $\mu$ $\sigma \tau \alpha \mathrm{l}$ based at a sanctuary of Apollo Pleurenos near Sardis, already attested in late Seleucid times. One does not normally associate Apollo with mysteries. It seems possible that an indigenous closed religious grouping of some kind has re-styled itself under the Greek title of $\mu$ v́ $\sigma \alpha{ }^{123}$

The initiations of the new inscription do not fit neatly into any of these categories. They are tied to a particular sanctuary. Non-initiates are spoken of as $\dot{\alpha} \mu$ í $\tau$ tor as well as as $\dot{\alpha} \tau \varepsilon \dot{\lambda} \lambda \varepsilon \sigma \tau o l . ~ O n$ the other hand, the initiation offered is closer to entry into a cult society than a unique, life-changing experience: it is clearly envisaged that initiates will continue to frequent the shrine, and there is no mention of a revelation. In this sense our cult can be compared to the societies which, heirs to the 'wandering initiator' type of cult, have settled down in a fixed location. But what has emerged in this case is not a closed cult society. The restrictions on access for the uninitiated to particular parts of the sanctuary show that other parts were open to them, at least on occasions. No secure parallel presents itself for a sanctuary thus serving both an initiated and a lay community. ${ }^{124}$ One may think, however, of the later development in the cult of Isis, in 
which initiates apparently constituted an elite (of commitment and of wealth) amid a broader community of devotees.

An obvious question is whether initiations accompanied the goddess from wherever she came from, or were added to the cult in Greece. Clear evidence for such practices is hard to find from outside Greece or regions subject to Greek influence. Standard handbooks of the various ancient near eastern religions do not speak of them. ${ }^{125}$ It is generally accepted that Herodotus was misapplying a Greek concept when he claimed that the Egyptians described the Khoak festival of Osiris as Mysteries. ${ }^{126} \mathrm{~A}$ celebrated

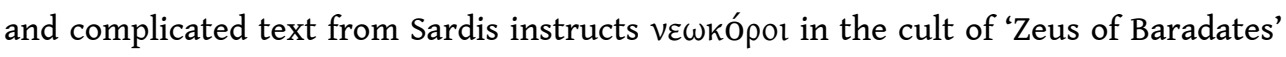

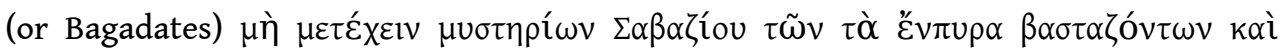

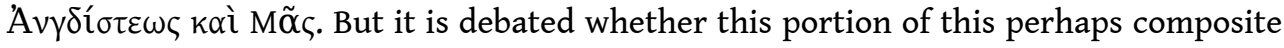
text belongs in 366/5 (or even 426/5) BC or rather in the Roman period. ${ }^{127}$ Even if we accept an early date, all other evidence on the cult of Sabazius and Angdistis and Ma suggests that 'mysteries' here means 'ecstatic rites' (possibly preceded by some form of initiation), ${ }^{128}$ certainly not Mysteries revealed at a fixed site in the style of Eleusis or Samothrace. At Thuria in Messenia in the first century BC, a benefactor who had promised to provide oil throughout his life for the 'days of the Mysteries' of what must, from the context, have been the Syrian goddess, was granted a front seat at those Mysteries and a place of honour in the procession. This text has been associated with the theatres found in other Syrian sanctuaries, most notably in that of Atargatis and Hadad on Delos. ${ }^{129}$ But there is no mention of initiation or mysteries in the quite numerous documents relating to that Delian cult; Will in his publication of the sanctuary sees the theatre as intended for 'festivals at which divine images were led in procession before the community of worshippers', a community which the very size of the theatre requires us to envisage as open and non-exclusive. ${ }^{130}$ To revert to Thuria, it lies at one end of a valley at the other end of which is Andania, site of authentic Greek Mysteries, and rivalrous imitation by Thuria of the prestigious neighbour must be a serious possibility. ${ }^{131}$ Whether this would have meant mere re-naming of a ritual of display, such as that to be postulated for Delos, or actual re-shaping to involve an initiation, is not clear; but in neither case do we have reliable evidence for Mysteries brought from Syria. The probability is that it was within Greece that the rites of our cult received their initiatory/mystic shape. One might speculate that part of this process was the extension to ordinary initiates of ritual requirements such as 'shaving' (below) ${ }^{132}$ hitherto forming part of the installation of cult functionaries in their office.

When did initiation happen? The day-by-day listing of the rituals of the month Itonios

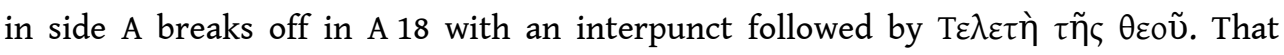
juxtaposition may suggest that initiation typically occurred in the context of the E/ Aloulaia in Itonios. But we cannot be sure that it was pinned to a fixed point; the priestess might have conducted it at various times, when there was demand. Another possible indication comes from the reference to an $\dot{\alpha} \gamma \varepsilon \rho \mu o ́ c$, apparently imposed on the initiand as a requirement, in A 25-26. The ó $\gamma \varepsilon p \mu o i ́$ on side B (17-21) fall on Itonios $10-12$, in the run up to the Eloulaia. If that by initiands formed part of the same collecting operation, the $\tau \varepsilon \lambda \varepsilon \tau \eta$ is pinned to Itonios by a different argument. ${ }^{133}$ But this is far from certain.

44 A different uncertainty arises from variations in terminology. In A 3-4 and A 8 oi

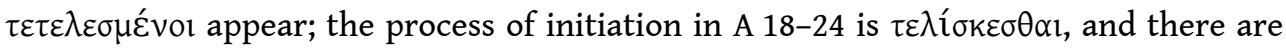

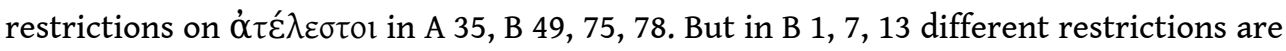




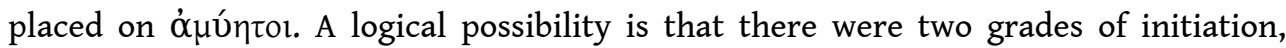
comparable (if differently named) to the distinction at Eleusis and Samothrace between mystai and epoptai. On that view, the difference between the restrictions apparently imposed on the two groups would arise because it did not need stating that the restrictions affecting those who had reached the higher grade of initiation also applied to the lesser: the $\dot{\alpha} \mu u$ inol, if they were the lower grade, ${ }^{134}$ would be subject to all the restrictions placed on the $\dot{\alpha} \tau \dot{\varepsilon} \lambda \varepsilon \sigma \tau o l$, plus some of their own. But it is more plausible that the variation is due to careless drafting, particularly because it only occurs in negative expressions: for the two terms used synonymously cf. e.g. Plato, Phaedo, 69c ô $\varsigma$

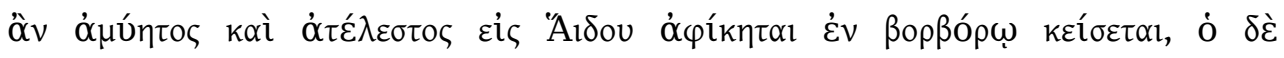

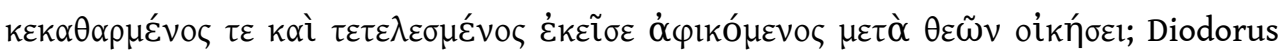

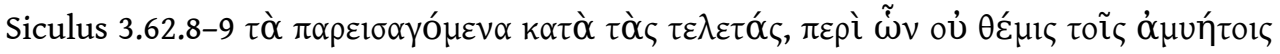

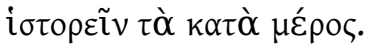

A harder complication arises from A 18-23. Two categories of person desiring initiation are apparently contrasted in two successive sentences; in the first sentence only one

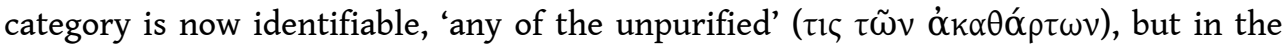

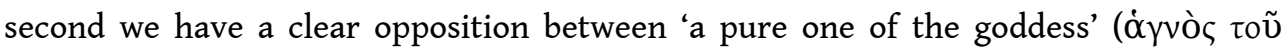

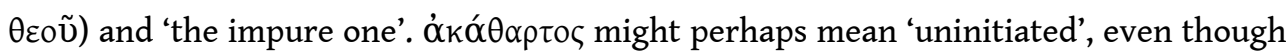
this usage lacks exact parallels ${ }^{135}$ and would introduce yet another variation from the

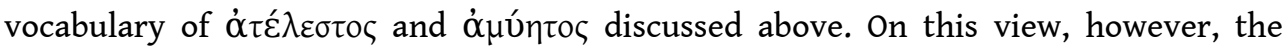
other category ought to be that of the initiated, and we are left to wonder why, if already initiated, they would need to be initiated again. If the opposition is not between initiated and non-initiated, but between two categories of potential initiate, we have no

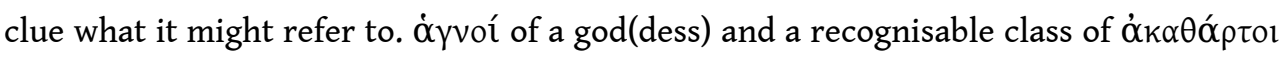
${ }^{136}$ are not otherwise attested.

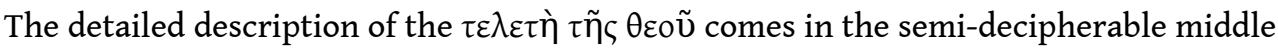
portion of side A (whether it continues into the almost completely abraded lower part is unclear). Much survives, but not enough to allow a convincing picture of the whole. There are purifications (see below), sacrifices and their accompanying table offerings, collections, a mysterious ritual involving a oxoĩvo , 'reed' or 'cord' or possibly 'reed basket', something placed 'in the hands' (of the goddess' statue?), a role (mysterious and unparallelled again) for individuals 'lifting the first bowl' and 'the second bowl': 'the priestess' is apparently mentioned only as a receiver of perquisites, though one might have expected her to play a central part. The detail that shines amid the gloom is the requirement, unique among Greek sacred laws but several times repeated,

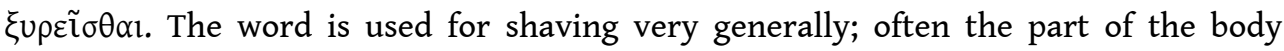
affected is specified, but in our text it is assumed that every participant in the cult will know what is meant. In a religious context much the commonest requirement is for shaving of the head (even if, in Hierapolis/Bambyke, iconography shows priests with shaven chins, not heads ${ }^{137}$ ); that, therefore, is probably the force here. As a rule for (male) participants, as opposed to priests, ${ }^{138}$ shaving of the head is most widely attested in Egyptian cults. ${ }^{139}$ But it also occurs elsewhere: according to Lucian, the first act of each male travelling to the goddess' panegyris at Hierapolis/Bambyke was to shave his head and eyebrows; Macrobius tells how the statue of Juppiter Heliopolitanus was carried during divinatory processions by provinciae proceres raso capite. ${ }^{140}$

There is, however, no trace of such requirements in the Egyptian or Syrian cults on Delos. Bremmer, discussing the requirement of a shaven head in the Isis mysteries of 
the high imperial period, has commented 'This has meant that many upper-class males will have refrained from this initiation, and it is noteworthy that Apuleius does not mention the shaving of Lucius' own head in his initiation into the Mysteries of Isis'.

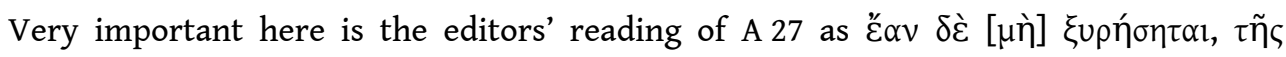

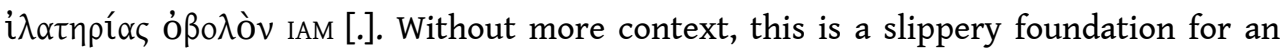
important claim. But it appears to state that one could exempt oneself from the shaving requirement by payment of an obol for a propitiatory offering. ${ }^{141}$ Indeed this option may even have been the cheaper if it exempted one from the three obols paid to the goddess for the $\sigma x$ oĩvo before shaving (A 26-7). ${ }^{142}$

As a requirement for women as well as men, shaving the head is much less common; in the cult of Isis, for instance, where (some, at least) men shaved, women wore headscarves. ${ }^{143}$ Much earlier, in an Akkadian text of the $13^{\text {th }}$ century BC from Emar, a high-priestess is shaved as part of her installation ritual, ${ }^{144}$ and both male and female Nazirites in the Hebrew Bible allow their hair to grow during the period of their vow and, when it is complete, "shall shave the consecrated head at the entrance of the tent of meeting" and burn the hair on the altar fire; ${ }^{145}$ the biblical material is commonly attributed to the $\mathrm{P}$ (riestly) source, which most scholars date ca. $600-400 \mathrm{BC}$ (though some regard it as earlier). But in the Greco-Roman period head-shaving by women appears to be attested only in the cult of Adonis at Byblos (and there only by Lucian), where it can be seen ${ }^{146}$ as an expression of mourning. If we accept that in initiations it was probably not asked of women, the regulations in our text concern men only. But women entered the precinct (B 26-29) and performed numerous functions in the cult; it is hard to believe they were excluded from initiation.

49 A further word in this section deserves comment. In A 18 an initiand is required to

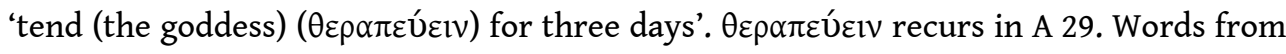
this root are standard for 'pay cult to' in a very general sense. ${ }^{147}$ In the hellenistic period there emerges the concept of the $\theta \varepsilon \rho \alpha \pi \varepsilon v \tau \alpha$ í of a particular god: it is first attested ${ }^{148}$ in relation to the Egyptian and Syrian gods on Delos, but later can cover e.g. the devotees of Asclepius at Pergamum. ${ }^{149}$ On the most widely accepted view, ${ }^{150}$ it designates all persons particularly attached to the cult of the god in question, not an association or sub-group. This implication of a particular commitment seems relevant here, and the time limitation implies the performance of specific acts; what they were we do not know.

What could initiates do that non-initiates could not? As we saw above, they had access to areas of the sanctuary, and rights of sacrifice on altars, from which non-initiates were excluded. But beyond this the text is maddeningly imprecise. In A 3-4 a

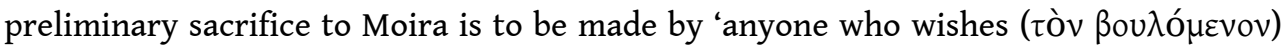
of the initiated'. In the many repetitions of the phrase 'any who wishes' (A 10,15), or 'if anyone wishes' (B 24, 35, etc.) it is unclear whether the restriction of A 3-4 to 'of the initiated' still applies or not. In one case it clearly does: at B 45-49 the prescription for 'anyone (who) wishes to make a complete "full table" for the goddess', specifies the food offerings that are to be brought, and concludes 'an uninitiated person does not taste of these': thus the bringer of the full table must be an initiate. But, by contrast with 'an uninitiated person does not taste of these', one might naturally take 'let anyone who pleases eat of it' in the immediately preceding regulation (B 45) as completely open. Similarly, 'anyone who wishes shall process' (B 64-65) at the Nisanaia or the Aloulaia sounds like a general invitation, even if 'all those who wish to sacrifice' 
(B 61) on the same occasions may well have been a more restricted group. Thus 'anyone who wishes' apparently in some cases but not others requires the tacit addition 'of the initiated'. A pervasive uncertainty is the consequence. It is arguable that the many sacrificial regulations of side B are addressed exclusively to initiates. But, on our interpretation, non-initiates are free to sacrifice fowl on the altar of Moira and Helios. 151

\section{Sacrificial Terms and Procedures}

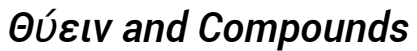

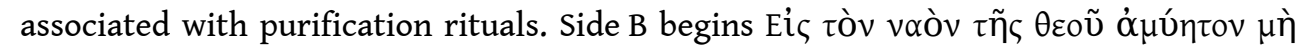

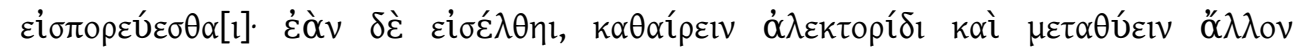

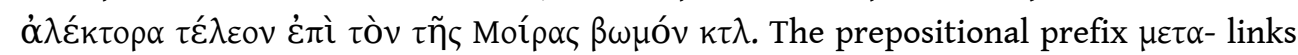
the sacrifice of the cock on the altar of Moira with the purification by means of a hen which precedes. The other occurrence of $\mu \varepsilon \tau \alpha \theta$ viclv is in precisely the same sort of

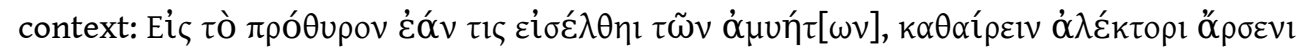

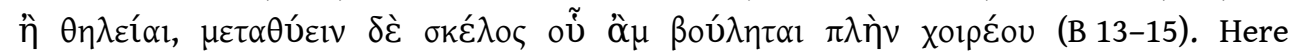
purification by a male or female fowl is followed by a very surprising $\mu \varepsilon \tau \alpha$-sacrifice (to which we will return), the leg of an animal of any species except pig, that is a portion of an animal that has already been butchered. The compound $\dot{\varepsilon} \pi \theta \theta \dot{v} \varepsilon v$ is used in the same

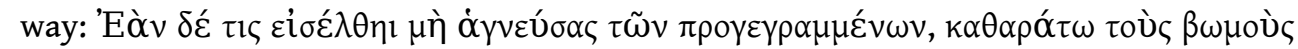

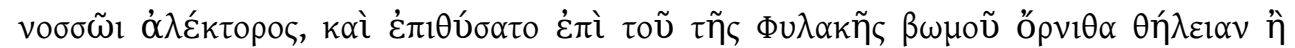

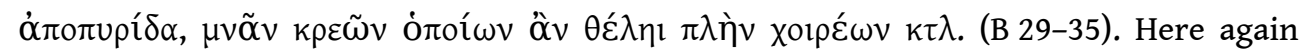
purification, in this case by a cockerel (young male chicken), is accompanied by a sacrifice, closely linked to it by the غ̇ $\pi$-compound, of a female chicken or a small fish and of "a mna of meat of any kind the sacrificer wishes except pork". In this case the prepositional prefix may be $\dot{\varepsilon} \pi-$ rather than $\mu \varepsilon \tau \alpha-$ because of the immediately

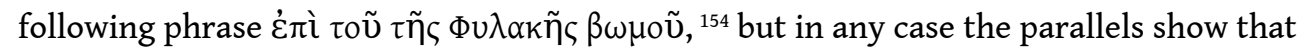

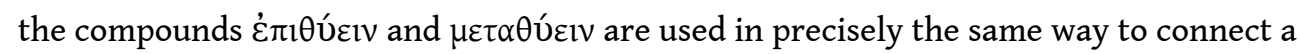
sacrifice closely with a preceding purification. We also have examples of $\dot{\pi} \pi \theta$ v́cı from 
Cos and Cyrene. In one inscription of the mid-fourth century from Cos the "taker of the kings' perquisites" sacrifices an animal, "provides offerings" (iંpò $\pi \alpha \rho \varepsilon ́ x \varepsilon l)$, and

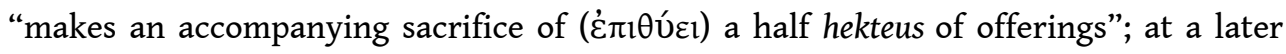
stage of the same ritual sequence, a priest making a preliminary holocaust of a pig cleans and burns its intestines and "is to make an accompanying sacrifice of offerings

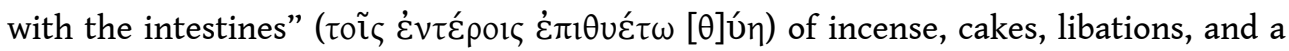
woolen fillet. ${ }^{155}$ In another Coan inscription of roughly the same date a purification

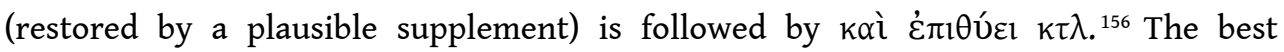
epigraphical comparanda for the use in our text, however, are three passages in the late-fourth-century cathartic law of Cyrene which require that a bride or pregnant woman who incurs various avoidable pollutions purify the sanctuary of Artemis and

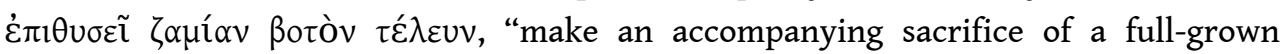
animal as a penalty". ${ }^{157}$ In all these cases the prepositional prefixes seem intended to make clear that the sacrifice is neither an independent ritual nor an elective option but a compulsory accompaniment to the preceding rite. ${ }^{158}$ In many cases what precedes is a purification, and in some cases, whether explicitly or implicitly, the accompanying sacrifice is a penalty or fine for the impurity in question.

One may compare a Cretan inscription of the mid-fifth to early fourth century BC from

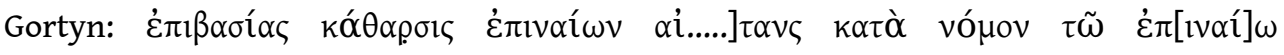

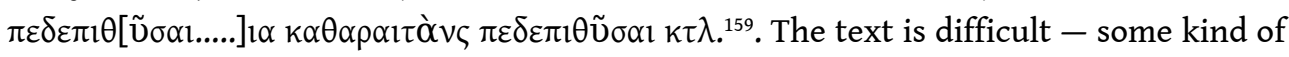
purification at marine embarkation seems to be the context - but a purificatory rite in the one line and mention of "purifying officials" in the other are here too followed by a compound of $\theta$ viclv which links the following sacrifice with the purificatory rite by means of the double prepositional prefix $\pi \varepsilon \delta \varepsilon \pi l-(=\mu \varepsilon \tau \varepsilon \pi l-)$. The new text and the Cretan inscription aid interpretation of what was until now the only attested occurrence of $\mu \varepsilon \tau \alpha \theta$ viclv, in a fifth-century Bc inscription from Delphi which forbids the

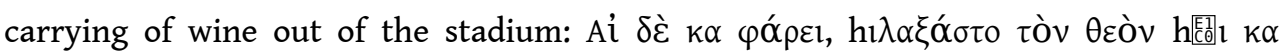

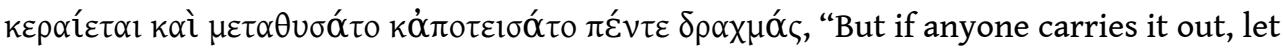
him propitiate the god for whom it is mixed and make an associated sacrifice and pay a fine of five drachmas". ${ }^{160}$ Translations of $\mu \varepsilon \tau \alpha \theta v \sigma \alpha ́$ to here have been very various indeed - Buck's "make an offering in its place" being the most plausible of those previously suggested ${ }^{161}$-but the new parallels favour the conclusion that whatever act of propitiation hi $\lambda \alpha \xi \alpha$ ó $\sigma o$ denoted had to be accompanied by a sacrifice. Perhaps the most telling exemplification of a close connection between purification and sacrifice, though it lacks the prepositional prefix, is a passage at the end of the inscribed lead tablet from Selinous published in 1993. A detailed set of instructions about ritual

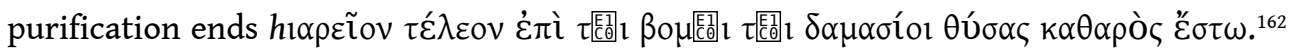
Here the sacrifice marks the completion of or perhaps even gives ritual effect to the strictly purificatory rites that precede it, and it may well be that the compounds of

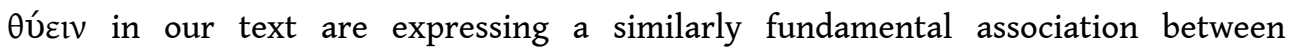
purification and sacrifice. ${ }^{163}$

Casabona said of the compound $\dot{\alpha} \pi$ rov́rıv, very reasonably given the limited evidence known hitherto, that "Il insiste sur la réalisation effective d'un sacrifice promis, dû, ou simplement dont l'accomplissement est attendu", and most of the passages Casabona quotes refer to votive or first-fruit sacrifices which are appropriately said to be "duly sacrificed". ${ }^{164}$ In other kinds of context, however, such as those in our inscription, it is

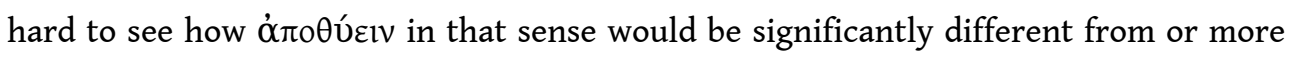




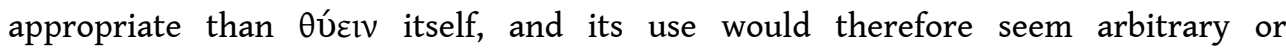
ornamental. We suggest rather that in the new text the prepositional prefix gives the verb the sense "bring a sacrificial (or ritual) sequence to completion by sacrificing", "sacrifice finally", or "finish by sacrificing" (LSJ sense D.2 of ó $\pi$ ó in composition). At A 3-15 we have a series of ritual acts on successive days: on the twelfth initiates make preliminary sacrifice to Moira; on the thirteenth the temple, peristyle, door-panels, and gateway of the goddess are cleansed, sacrifice is made to Mogga, and things in the sanctuary that have become impure are purified by various cultic functionaries and initiates; on the fourteenth the (image of the) goddess and her altar are adorned, with the prescription $\dot{\alpha} \pi \circ \theta \dot{v} \varepsilon \imath v \tau \tilde{\omega}$ ' $H \lambda i^{\omega} \omega \mathrm{l}$ (A 9); on the fifteenth sacrifice is made to Syrian Pan and during the night a pot is filled from a spring; and on the sixteenth the pot is opened and sacrifice is made to Moira. This ritual complex falls into two phases: first the sequence undertaken by the priestess and sanctuary personnel of preliminary sacrifice / cleansing and purification of the sanctuary / adornment of the goddess's image and altar on the twelfth, thirteenth and fourteenth, and then the sequence involving "anyone who wishes" of sacrifice to Pan and pot-filling / pot-opening and sacrifice to Moira on the fifteenth and sixteenth. We suggest that the sense of the

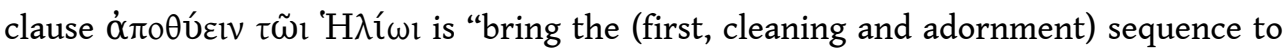
completion by sacrificing to Helios" - an appropriate god before whom to display the freshly made-over image of the goddess. Similarly we suggest that the phrase $\tau \alpha \tilde{v} \tau \alpha$

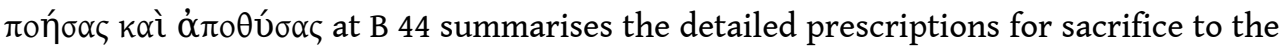
goddess "by the Greek rite" laid out at length in B 35-43 and means "having done these things and brought this sacrificial ritual to completion".

\section{Sacrifice "By the Greek Rite"}

56 If it is possible to be confident about the sense of the compounds of $\theta$ vicu that are securely read in our text, the same cannot be said of the text's provision for sacrificing

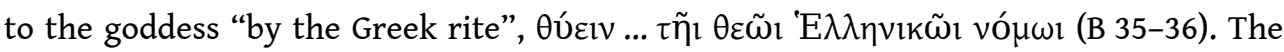
procedure is set out in great detail (B 35-45). The person wishing to sacrifice in this way is permitted to offer any victim he wishes except a pig (36); in connection with the sacrifice $\tau \grave{\alpha} \dot{\varepsilon} \pi \imath \tau \imath \theta \varepsilon \dot{\mu \varepsilon v \alpha, ~ " t h e ~ o f f e r i n g s ~ t h a t ~ a r e ~ p l a c e d ~ o n ~ t h e ~ t a b l e " ~-~ t w o ~ t y p e s ~ o f ~}$

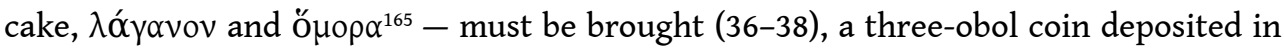
the collecting-box (38), oil provided for the lamp (38-39), a chous (six-pint measure) of wine "from the sanctuary" put "into the mixing-bowl" (39), and the boiled breast and one raw leg placed on the table (39-40). The priestess is to take the innards, ${ }^{166}$ liver, lungs, diaphragm, left kidney, and tongue (40-41); but the right kidney, right akrokolion (foot?), heart, and omentum, and the front leg (lit. "the leg that joins the breast", presumably by implication the right front leg) and the part of the tail that is customary in rites should go onto the fire (41-43). ${ }^{167}$ "Having done these things and brought this sacrificial ritual to completion", the person offering sacrifice "is to bring another victim of whatever species he wishes, and anyone who wishes may eat of it" (44-45).

What is "Greek" about this method of sacrifice?168 We favour one among various conceivable explanations as involving fewer oddities than the others. At first sight the "Greek rite" may appear to be one among different options available for the sacrifice of any animal, but we think it rather distinguishes between victims seen as typical of 
Greek sacrifice and those of a different culture, or at any rate of smaller size. On this view, we would schematise the context in which the specification occurs as follows:

1. A section on preliminary sacrifices, either incense or "if anyone wishes to sacrifice white chickens, let him sacrifice males to Men, female to Artemis, and if he wants (to sacrifice) lambs, similarly" (B 22-26).

2. The sentence speaking of the Greek rite: "but if anyone wishes to sacrifice to the goddess by the Greek rite, it is permitted (to sacrifice) whatever he likes except pig" (B 35-36).

3. The long sentence specifying dues and offerings to be made "to accompany the sacrifice"; these include perquisites for the priestess and portions of the animal which are removed to be burnt on the fire (B 36-43).

4. The final sentence concerning the additional victim (44-45).

It is not immediately clear whether (3) specifies in detail how the Greek rite is to be conducted, or rather relates to any sacrifice whatsoever including that of birds mentioned in (1). But a later section treating the sacrifice of bovines concludes $\tau \grave{\alpha}$ i i $\rho \grave{\alpha}$

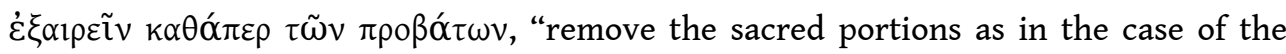
sheep" (B 60-61), and if this refers to another entry in our inscription it is probably a back reference to (3), which would therefore refer primarily to the sacrifice not of any animals whatsoever but of sheep, and thus continue the thought not of (1) but of (2). "The Greek rite" therefore seems to refer to sacrifice of ovines (and doubtless caprines) -though we think the same rite is also used for bovines and so really applies to larger animals in general - with removal of certain portions for burning; it is contrasted with the sacrifice of birds, no portions of which appear to be burnt in this text except in the case of holocaust. Could then the larger victims be sacrificed either in the Greek way or in some other? There is no sign in the text that any alternative, non-Greek way of sacrificing such victims when full-grown was envisaged (but lambs appear with birds in [1]); if these were the victims, they were dealt with Graeco ritu. Conversely, there is no reason to think that the modes envisaged here of sacrificing birds were contrary to Greek custom. We know that Greeks did sacrifice birds, but the question of how they did so is one seldom posed, for lack of evidence; they cut out portions for the priest, ${ }^{169}$ as is also done here, but there is no sign that they burnt their thigh bones for the gods (nor, certainly, that they did not). It is then arguable that the distinction is not so much between modes of sacrifice as between small victims such as fowl (and lambs) and fullgrown animals, the former being seen as the typical non-Greek, the latter the typical Greek victims (as indeed they were), and only the latter yielding portions which are taken out to be burnt. There is moreover clear evidence in the text that an ovine or caprine was the kind of victim normally used in the Greek rite. The cash payments specified as accompaniments to the various forms of sacrifice are one obol for a bird (B 54), one and a half obols for a goose (B 55), three obols for a Greek rite victim (B 38), and a gold piece for a bovine (B 60): that scale certainly suits and perhaps requires the conclusion that the normal victim in the Greek rite is a sheep or goat. ${ }^{170}$ It is also relevant that i $\varepsilon \rho \varepsilon \tilde{o} o v$, the term applied to the additional victim at the end of the prescriptions, commonly means "sheep" when used without further specification, particularly in the Hellenistic period. ${ }^{171}$

59 This conclusion is open to objections which need to be addressed. An opening protasis

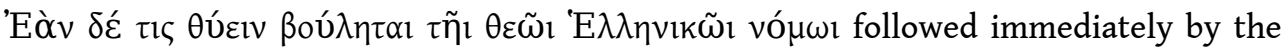

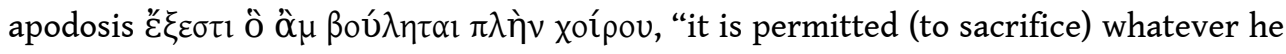


likes except pig" may seem a strange way to begin the description of a form of sacrifice defined chiefly by its application to larger animals, and in the immediate context to sheep and goats. But we have argued that the Greekness of the 'Greek rite' refers primarily to the animals typically sacrificed by the Greeks. Greeks did often sacrifice pigs, if less often than sheep: whence perhaps the need to make the exclusion explicit. Permitting some Greek sacrificial preferences was not to be taken as permitting all.

There is no doubt that the sequence of entries is very odd if we are correct that the "Greek rite" refers to larger animals: a full description of the Greek rite referring in its immediate context to ovines and caprines is followed by an entry on trapezoplesia, another on the panemerizein ritual, and a third on censing the goddess's image, then by an entry on sacrifice of birds and geese that is not conducted according to the Greek rite, and only then by a section on sacrifice of bovines with a cross-reference back past all this non-Greek-rite material to the Greek rite, which on any sensible scheme it ought to follow immediately. We cannot account for this except as muddle, but there is a good deal of muddle elsewhere in the text. The regulation of collections at B 17-23 seems completely out of place between the end of the regulations restricting access of the uninitiated to temple and prothyron and the beginning of the regulations of sacrifice to the goddess, and the passage regulating women's impurities (B 26-35) is out of place between the regulations of preliminary sacrifices to Phylake and Mên (B 22-26) and those of primary sacrifices to the goddess.

61 We conclude, then, that an ovine or caprine was - unsurprisingly - the usual victim in a "Greek Rite" sacrifice, and that the full description of that rite is therefore given when the composer deals with those victims. His readers will understand that he has in mind (without explicitly specifying) ovines and caprines, as the level of cash payment confirms. For unfathomable reasons he postponed the corresponding entry on bovines so that it follows a good deal of material that has nothing to do with the Greek rite, but readers with experience of sacrificial rites for the goddess will have understood his back-reference readily enough as there were only two modes of sacrificing larger animals to her, the Greek rite and holocaust.

The distinction between birds (and lambs) and larger animals is probably all there is to the "Greekness" of the Greek rite; birds, so prominent in this cult, are - as we have seen above - much more at home in Near Eastern cult than in Greek. There are, however, two other aspects of the rite that make it distinctive; neither of these can, we think, have been the criterion of Greekness, but both are remarkable features of it that call for attention.

The first of these distinctive features is burning of substantial portions of the victim far more than the usual thigh-bones, fat, and tail - for which Scullion has coined the term "moirocaust". ${ }^{172}$ The specific prescriptions in such rites vary, but a ninth is a typical proportion of the meat that is burnt, ${ }^{173}$ and the portions to be put onto the fire at Marmarini seem roughly in line with that sort of amount. If we are right that Greek rite and holocaust are the only methods of sacrificing larger animals to the goddess, it is remarkable, even startling, that 'standard' Greek sacrifice with its modest portion for the divinity is not permitted, but only two modes of sacrifice involving very heavy burning. Perhaps more meat was burnt in this Greek cult than in any other known to us in comparable detail, ${ }^{174}$ and we wish we could confidently explain why. Hybridity, however - in particular the much greater prominence of holocaust sacrifice in Near Eastern cults by contrast with its exceptional status in Greek, discussed above - 
probably provides at least a partial explanation. It is also notable that the Marmarini text offers no criterion by which "anyone who wishes" to sacrifice might choose between Greek-rite moirocaust and holocaust sacrifice. Knowledge of established criteria may have been assumed, but the phraseology of choice suggests that the sacrificer's decision will depend on his or her own circumstances, aims, and sense of what is appropriate on a given occasion. Much of our evidence for Greek sacrifice attests obligatory offerings on particular, recurrent occasions, but elective sacrifices by private persons whose modality was determined by the kind of ad hoc judgements that our text seems to allow for must have been far more common than the general run of our evidence suggests. In this regard as in others, however, we must reckon with the Near Eastern influences that make sacrificial practice at Marmarini distinctive.

The second distinctive aspect of the Greek rite has to do with the final clause of the

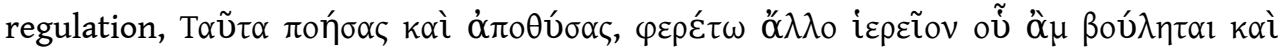

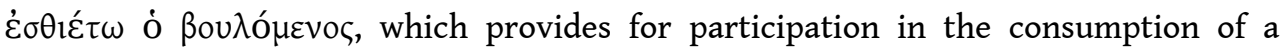
supplementary victim - rather than the victim whose sacrifice to the goddess, doubtless on her altar, has been so painstakingly described - by "anyone who wishes". It seems to us probable that this second animal is not obligatory. The sentence probably means "after doing this and completing this sacrifice, let him bring another victim of whatever species he pleases and let anyone who pleases eat of it", but it might mean "Let anyone who pleases, after doing this and completing this sacrifice, bring and eat another victim of whatever species he pleases". On either reading, however, what is intended is surely a 'supplementary' option rather than a prescribed obligation. Cooking and dining on the meat of Greek sacrificial victims normally took place not at the altar but in a "dining area" elsewhere in the sanctuary, ${ }^{175}$ and there is a very striking difference between the elaborate prescriptions for the ritual treatment of the first victim and the simple provision that a second victim may be 'brought and eaten'. The meat of a second animal will not have come amiss once all of the prescribed tableofferings, priestly perquisites, and portions for the fire have been removed from the first, and the text suggests that the second animal's role was primarily to load the banquet table. It is evidently not to be sacrificed in the same way as the first - the final clause can hardly mean "repeat the procedure with a second victim" - and this both sets a limit on table-offerings and perquisites and increases the meat available for the inclusive banqueting it explicitly provides for. It is remarkable that no ritual treatment of this second animal is prescribed. If some method of sacrifice other than the Greek rite is to be used - 'standard' sacrifice, perhaps, with removal only of thigh-bones wrapped in fat, tail, and splanchna - this very detailed regulation oddly fails to specify what it is. One would also like to know whether "whoever wishes" merely means "anyone among those initiates present at the Greek-rite sacrifice at the goddess's altar who wishes to stay on and dine" or envisages wider participation in the post-sacrificial banquet, perhaps even by uninitiated persons (cf.p. 238 above). In any case, the supplementary animal is both distinctive and remarkable.

\section{Sacrificial Novelties}

The text's detailed prescriptions for sacrifice by the Greek rite are followed by less elaborate regulations of two previously unknown (or in the first case unrecognised)

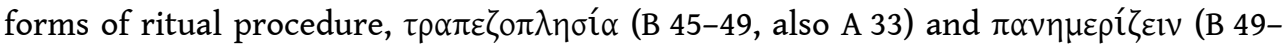

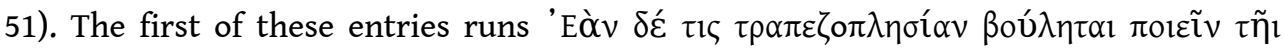




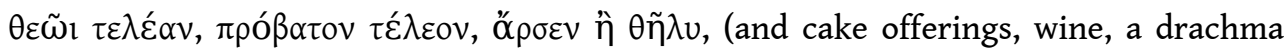

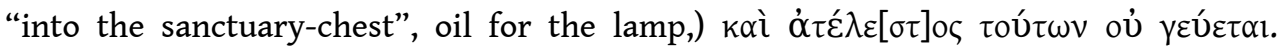
Decourt notes that $\tau \rho \alpha \pi \varepsilon \zeta o \pi \lambda \eta \sigma i \alpha$ is a hapax legomenon and compares it with

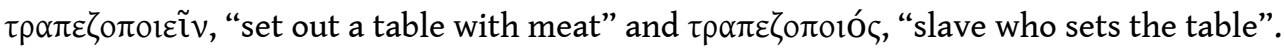
${ }^{176}$ There is however a much closer parallel in a second-century-AD inscription from Sounion in Attica recording a slave's foundation of a cult for the Anatolian god also

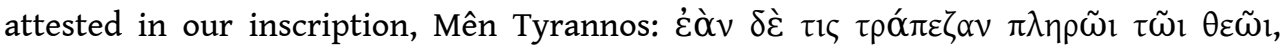

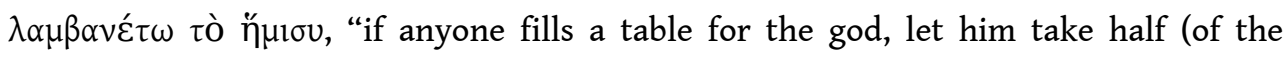

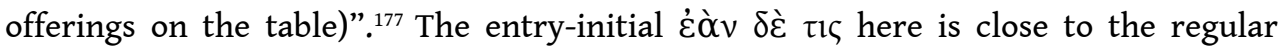
phraseology of the Marmarini inscription, and there can be little doubt that the ritual of "table-filling" also shares common ancestry, even if at Marmarini it honours the goddess rather than Mên. In standard Greek practice - and, as we have seen, elsewhere in our inscription - offerings on the sanctuary-table are an element of what is presented primarily as a ritual of sacrifice, normally involve vegetable offerings and often also portions of the meat of the sacrificial victim, and are offerings to the god, that is are made over to the sanctuary. In Marmarini, by contrast, sacrifice of a "fully grown male or female sheep" is an element of what is presented primarily as a "perfect" $\tau \rho \alpha \pi \varepsilon \zeta о \pi \lambda \eta \sigma i ́ \alpha$; it therefore seems probable that most or all of the meat goes onto the table, and, as we can infer from the prohibition on the uninitiated tasting the table-offerings, it does not all remain there to be taken by the sanctuary officials but is in part consumed by the initiates who attend. No inference is required in the case of the parallel "table-filling" for Mên Tyrannos, where the person sacrificing is explicitly allowed to take half of the offerings, and there is a parallel for this in another passage of our text. The entry governing sacrifice "by whoever desires and is willing" to "Pan

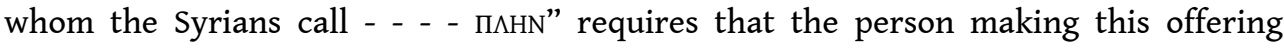

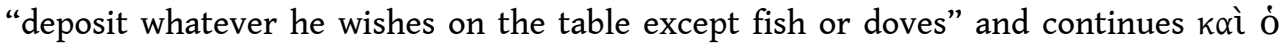

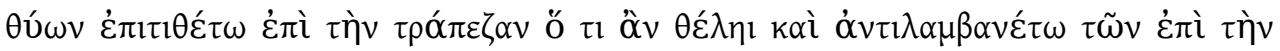

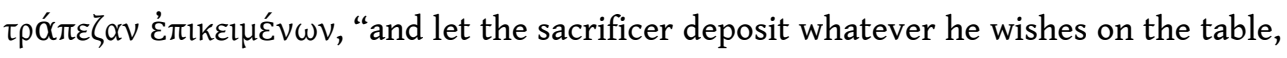
and take in exchange from the things deposited on the table" (A 9-14). Inscriptions often attest the taking of table-offerings as perquisites by priests, but what they are entitled to (whether specified parts or - as in the case of the person filling Mên Tyrannos' table at Sounion - a specified proportion) is elsewhere strictly defined, ${ }^{178}$ and the normal assumption is that the rest becomes the property of the sanctuary. Athenaeus tells us that the Alexandrians dedicate wafer-bread cooked over coals to

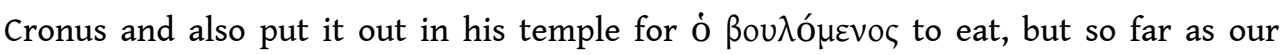
evidence goes this seems an unusual practice. ${ }^{179}$ We will return shortly to the question of quite what may be going on in all these 'participatory' table-offerings.

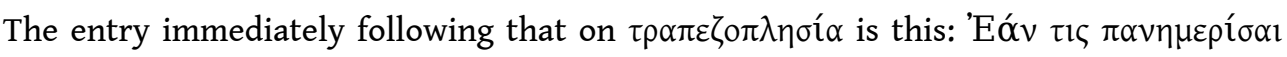

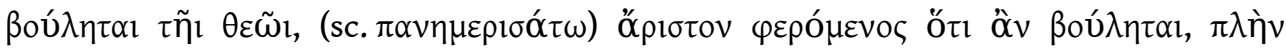

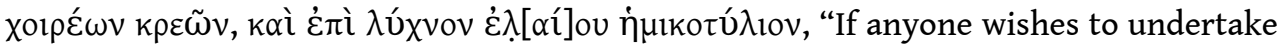
the 'all-day ritual' for the goddess, let him do so, bringing with him a lunch of whatever he wishes except pork meat and a hemikotulion of oil for the lamp" (B 49-50) ${ }^{180}$. The verb

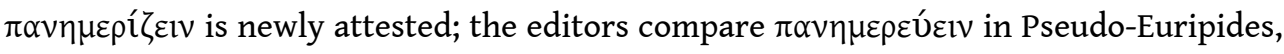
Rhesus, ${ }^{181}$ but the -i $\zeta \varepsilon v v$ formation was doubtless coined to designate a ritual lasting all day. Even if the term is new, however, the surprising thing is what would be called in British English the "packed lunch". A number of inscriptions mention provision of óplotov in a sanctuary, often naming the functionaries or officials who are to receive or 
provide the lunch, ${ }^{182}$ but whereas one assumed in those cases that the lunch consisted of food that was already in the sanctuary and that any meat in it would have come from victims that had been sacrificed there, it is clear here that the lunch is brought "packed" into the sanctuary, and that any meat in it might have been carried home from a previous sacrifice in the goddess's sanctuary but might also have come from a victim sacrificed to another god or from an animal that was never sacrificed. ${ }^{183}$ This is surprising, but the inscription contains still more surprising passages which may help us to understand this one.

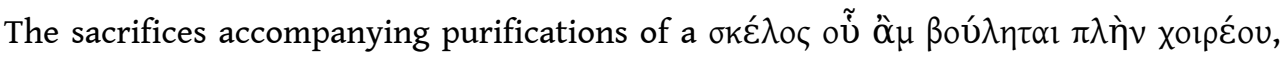
"leg of whatever (the sacrificer) pleases except pork" at B 15 and of a $\mu \nu \tilde{\alpha} v \kappa \rho \varepsilon \tilde{\omega} v$

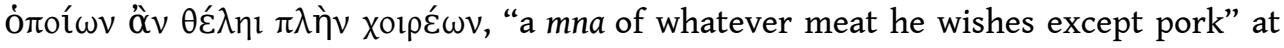
B 32-33 are very surprising indeed. In both cases, an animal must already have been slaughtered and butchered before these portions of its meat were "sacrificed". This raises urgent questions: Where did the meat come from? From an animal previously sacrificed, and in this sanctuary? If so, it might seem odd that the portions sacrificed in our passage are as it were doing 'double duty'.

One possible explanation would be that these portions are incinerated on the altar, and that by becoming unavailable for human use (as they would not be if they were portions of an animal sacrificed normally) they make an acceptable sacrificial offering. Another possibility is that "sacrifices" of a leg and a weight of meat are equivalent to the widely-attested placing of portions of meat "on the table" as perquisites for the

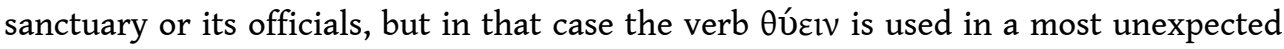

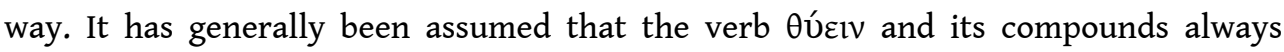
implies that an animal of which it is used is brought alive to an altar and killed, and that some portion of it - as perhaps of any vegetable offering to which the verb is applied ${ }^{184}$ - is burnt. ${ }^{185}$ The first possible explanation therefore seems safer than the second, but it is impossible to interpret this new and wholly unexpected phenomenon with any confidence.

It may be that these surprising requirements should be considered alongside some other unusual prescriptions in the new text. The passage about sacrifice of a mna of

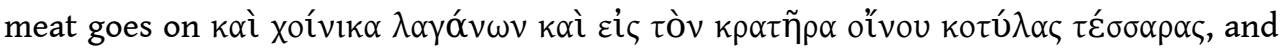
this requirement of "wine into the krater" occurs four times elsewhere. ${ }^{186}$ In one of these cases it is specified that the wine for the mixing-pot come "from the sanctuary

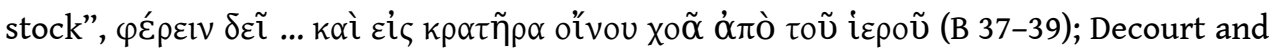
Tziphalias suppose that that this is also the sense of the damaged line A 24,

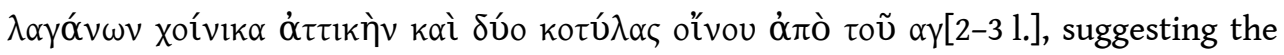
supplement $\dot{\alpha} \gamma\left[v o \tilde{v}\right.$, but this seems to us very unlikely. ${ }^{187}$ It is odd that those sacrificing should pour measures of wine into a - presumably common - mixing-pot, sometimes doing so with 'sanctuary wine' conveyed from a separate container.

One wonders whether wine put into the krater and thus made over to the sanctuary might later serve as the wine "from the sanctuary stock" which sacrificers were required to offer and presumably therefore to buy (B 39). If that were so, it might provide a parallel for the "leg" or "mna of meat" sacrificed at B 15 and B 32-3, which could conceivably have been purchased from the sanctuary's stock of table-offerings or from priest(esse)s who had received it as perquisite-portions, which would not only increase the proportion of sanctuary and priestly income received in cash rather than kind but also make any given animal go further as a source of meat for sacrificial 
offerings. If so, there would be considerable exchange - re-use and selling-on of wine and portions of meat - happening in the sanctuary, and the sacrificer's "taking in exchange" from the table offerings to Pan at A 12-13 (like the comparable taking of half of the table-filling offerings for Mên at Sounion) would fit into such a system of internal exchange. But, again, this is speculative - possibilities worth raising but no more than possibilities. An alternative explanation would be that these oddities are not curious if comprehensible developments of ordinary Greek ritual practice but foreign practices - or perhaps 'foreignizing' practices - explicable on the basis of the nonGreek origins of the cult. Dinner-offerings played a central role in Mesopotamian sacrifice, ${ }^{188}$ which perhaps, in this respect as in others, has influenced cultic practice at Marmarini.

71 A further, remarkable feature of the text is the frequency with which phrases such as

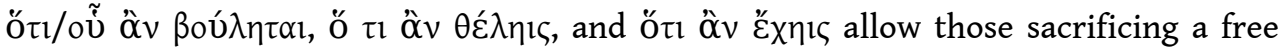
choice as to the victim's species. The phraseology "the person wishing to do X", e.g. $\dot{O}$

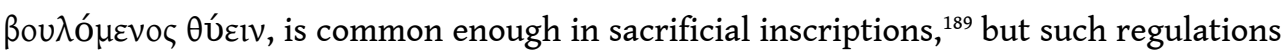
normally specify victims by species and often by gender, age, colour, and so on; explicit examples of free (or wide) choice of victim as in our text are few. A fifth-century BC regulation from Thasos allows choice of gender and (with qualifications) species for

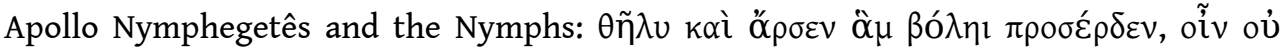

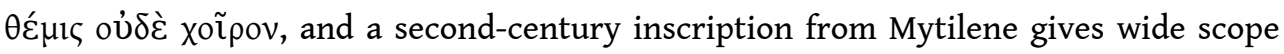

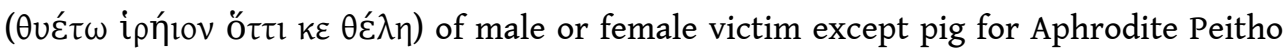
and Hermes. ${ }^{190}$ The freest choice previously attested epigraphically is in a regulation of

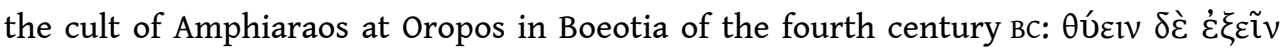

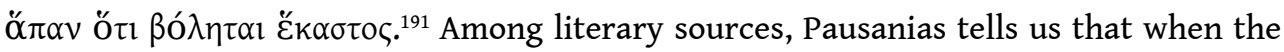

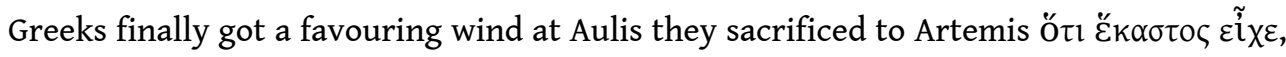

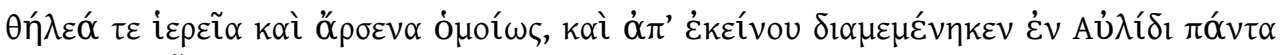

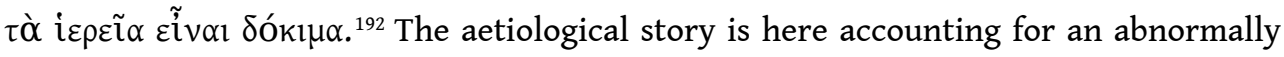
non-prescriptive approach to sacrifice. Wide choice as to victim, then, is very common in our text (generally with the qualification that pork is forbidden ${ }^{193}$ ) but would seem to be uncommon elsewhere. It is however possible that the epigraphical record is misleading, that public bodies specify victims in their regulations because they have to control the budget and to follow certain inherited traditions for public rites, but that individuals were free - subject only to cult-specific prohibitions such as that on pigs to offer any victim they pleased. One cannot be confident that this was so - our own text, for example, explicitly provides that among larger animals only a full-grown ram or male lamb may be holocaust-sacrificed (B 66) - but it is perfectly plausible. Whether or not our cult is exceptionally permissive in reality, it is certainly exceptional in the verbal stress that it lays on the point, perhaps because in a hybrid cult worshippers need to be told explicitly what is allowed.

\section{Holocausts}

72 The final set of sacrificial regulations on side B of the inscription (B 66-74) is devoted to holocaust sacrifice of various classes of victim: ram or male lamb (66-70), goose (70-73), and trubba ${ }^{194}$ or quail (73-74). It is notable that in the cases of holocausts of sheep and

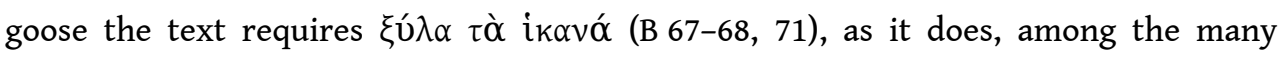
varieties of non-holocaustic sacrifices dealt with earlier, only in the case of the largest 
victims, bovines (B 59-60). The extra wood required for whole burning of sheep and goose is implicitly required also in the case of the smaller birds by the clause $\tau \grave{\alpha} \delta \bar{\varepsilon}$

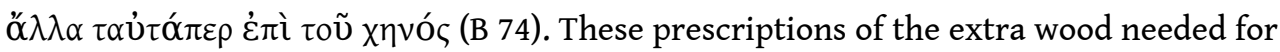
holocaust find a parallel in (and provide a parallel for) the recently published sacrificial regulations of the Attic deme of Aixone, where what must be holocaust sacrifices for Hagnê Theos require three-obols-worth of "larger wood" in addition to the two-obolsworth of firewood prescribed for other sacrifices. ${ }^{195}$ We also note that the holocaust prescriptions in our text require - as, among the earlier entries, only the prescription for the censing of the goddess's image does (B 52-53) - a good deal of incense and other aromatic material:;196 presumably they were added to the fire, but in any case holocaust at Marmarini was meant to be a sweet-smelling thing, and we have seen that this too may owe something to Near Eastern tradition.

73 None of these holocaust sacrifices is said to be "for the goddess", but it seems most likely that whoever drafted or cut the text, having kept up regular reference to the goddess as the divinity honoured throughout the prescriptions of Greek mode sacrifice,

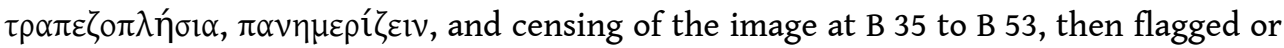
omitted reference to her as self-evident in the remainder of the 'standard' sacrificial entries at B 54-61, mentioned her in the festival regulations at B 61-65, and again omitted reference to her in the holocaust regulations at B 66-74, finally mentioning her again with reference to fowl sacrifice in the 'further rules' at the end of side B. This may seem a bold assumption, but it would be strange to conclude that those among these entries not explicitly connected with the goddess were in fact for other, unspecified recipients rather than for her. It is also possible, however, that the sacrificial procedures without a specified recipient are suitable for offerings either to the goddess or to any of the other divinities with altars who are named in the inscription but for whom no (or very few) dedicated sacrifices are prescribed.

74 An intriguing question about these holocausts is why among ovines only a male, whether ram or lamb, is to be holocaust-sacrificed. We have no explanation to suggest, but note that the pattern of sacrifices in the inscription distinguishes Phylake, who seems only to receive female victims (B 24-25, B 31-32), from "the goddess" who explicitly receives "male or female" victims at B 46 (cf. A 31-32), apparently a female chicken or a male goose at B 54-55, implicitly either a male or female in most of the other prescriptions, the ram or lamb holocaust, and finally sacrifice of female fowl either on the "great altar" or (if offered by an uninitiated person) on Moira's altar (B 76-77). This pattern of offerings coheres with the terminological distinction between (Artemis) Phylake and "the goddess", and it seems to us perfectly clear that the one is not to be identified with the other.

\section{Other Sacrificial Terms}

75 Three terms connected with consumption of the meat from sacrifices occur in the

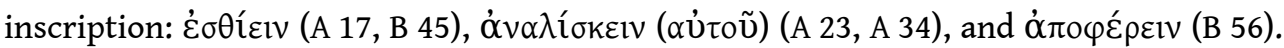
These mean respectively "eat", "consume (on the spot)", and "carry away", but it is unusual to encounter all three together, which raises interesting questions about how they are related, and in particular about how the first relates to the other two.

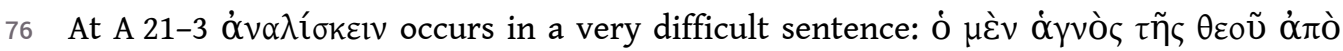

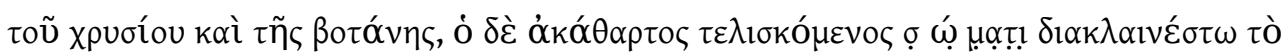




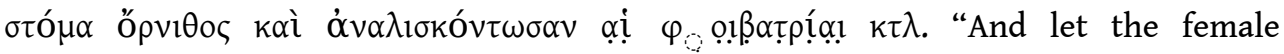
purification officials consume it" (viz the bird that has been killed), seems the likeliest rendering for the last four words. The context is also difficult at A 34-5:

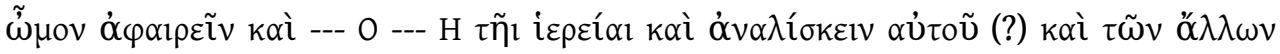

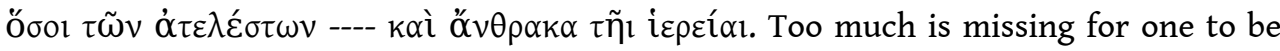
confident about the general sense, but it seems probable that we have here a new example of the requirement to "eat on the spot", expressed in the well-established phrase $\dot{\alpha} v \alpha \lambda i ́ \sigma \kappa \varepsilon l v ~ \alpha \dot{U} \tau o \tilde{u} .{ }^{197}$ This requirement is designed to prevent the common practice of carrying portions of the meat of the sacrificial victim away from the sanctuary, a practice mentioned in the inscription at B 55-56, where among the

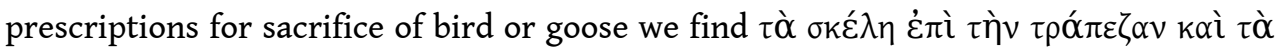

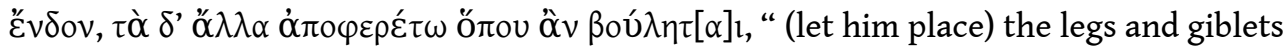
onto the sanctuary-table, but carry away the rest of the meat wherever he wishes". So far so neat and clear, but if $\dot{\alpha} v \alpha \lambda i ́ \sigma K \varepsilon I v ~ \alpha \dot{v} \tau o \tilde{u}$ means " (compulsorily) eat on the spot" and $\dot{\alpha} \pi$

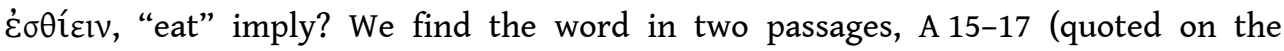

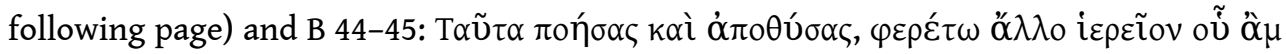

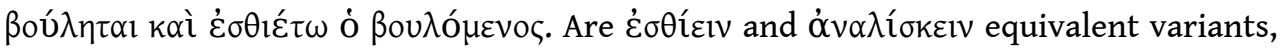

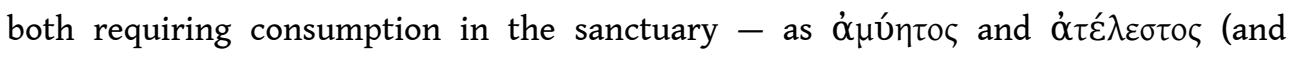

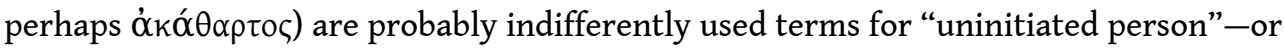

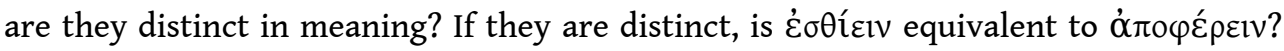

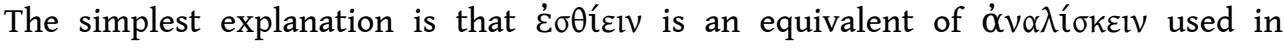
passages (such as the second) where ó ßou $\lambda$ ó $\mu \varepsilon v o \zeta$ is the subject because no individual

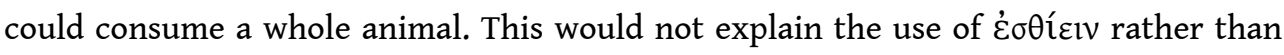
$\dot{\alpha} v \alpha \lambda i$ okeıv at A 17, but if the two terms are essentially equivalent it would not be surprising if they were used interchangeably.

\section{Other Rituals and Ritual Terms}

Three intriguing passages involve acts expressed by the verb $\beta \alpha$ ó $\lambda \lambda \varepsilon$ Evv:

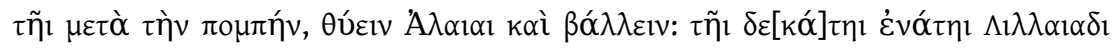

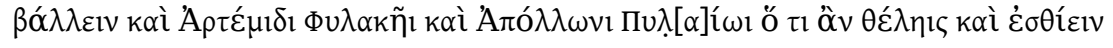

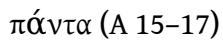

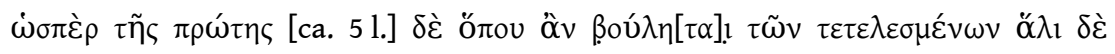
$\beta \alpha ́ \alpha \lambda \lambda \varepsilon i v$

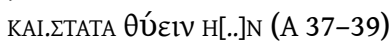

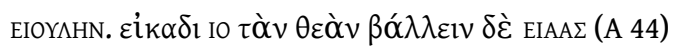

The context in all three passages is difficult, and in the third insufficient to determine the sense of the verb. The editors suggest that $\beta$ ó $\lambda \lambda \varepsilon$ viv means "jeter (ou déposer?)" ${ }^{198} \mathrm{We}$ suggest that in the first passage the verb means "put" (LSJ II.6) or "cast" onto an offering-table and in the second either "pour" 199 or "sprinkle" with saltwater or "sprinkle" with dry salt.

The second passage is most easily dealt with. The word ö $\lambda \zeta$, like $\theta$ á $\lambda \alpha \sigma \sigma \alpha$, can mean "saltwater", which is a well-known agent of purification, ${ }^{200}$ and though dry salt could be used for purificatory purposes, the only evidence of it being "thrown" or "cast" of which we are aware is a passage of Menander where salt (and lentils) are "cast into" 
springs from which purificatory water is to be taken. ${ }^{201}$ Ritual aspersion with saltwater is, by contrast, well attested ${ }^{202}$.

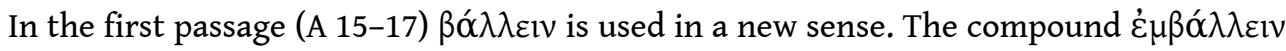
in the sense "throw into a sacrificial pit (or other receptacle)" is common enough, and the simplex might conceivably have that sense, but so far as we are aware there is no parallel for such an offering being retrieved and eaten. In A 16-7 $\beta \alpha$ ó $\lambda \lambda \varepsilon ı v$ stands alone,

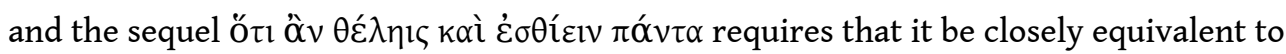

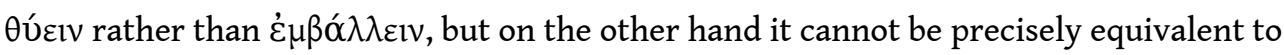
Өúciv, with which it is paired in the previous line. It might describe some type of sacrificial presentation preceding a meal, perhaps the "casting" of an offering onto the sanctuary table before it is eaten, in the case of Alaia along with (portions of) a sacrificed animal. This would perhaps cohere with the evidence discussed above ${ }^{203}$ for table-offerings going back into the hands of the sacrificer both in this text (A 11-13) and in the cult of Mên at Sounion, but it is no more than a plausible guess at the sense of yet another new and surprising usage.

\section{Purity, purifications and abstentions}

81 Concern for purity arises in the text at four and perhaps five levels: (a) general cleansing of the shrine (b) periods of exclusion for those in impure conditions (c) purification in preparation for initiation (d) purifications after specific pollutions and perhaps (e) abstentions prior to access to the shrine.

82 (a) General cleansing of the shrine. The run up to the Eloulaia begins on the twelfth with a preliminary sacrifice to Moira; on the thirteenth a general cleansing of the sanctuary is performed, and on the fourteenth the goddess and her altar are 'adorned'; ${ }^{204}$ the purificatory sequence ends with a sacrifice, apparently marked as a conclusion

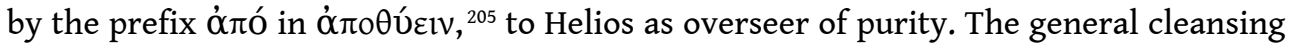
on the thirteenth is to be performed 'along with the priestess by the $\varphi$ oı $\beta \alpha \tau i$ í $\alpha$ and the

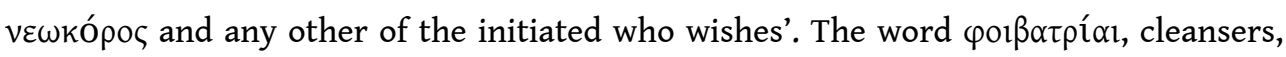
makes its first appearance outside ancient lexicography here, ${ }^{206}$ though cf. LSJ s.v.

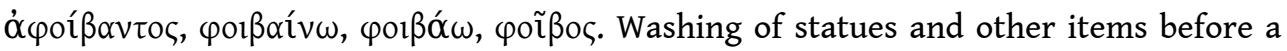
rite was commonplace; ${ }^{207}$ at Eleusis and Olympia special officials were charged with the

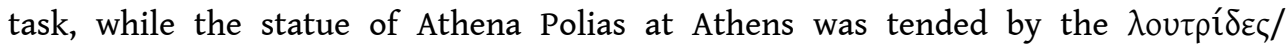
$\pi \lambda u v \tau$ í $\delta \varepsilon \varsigma$ doubtless drawn from the genos of the Praxiergidai. ${ }^{208}$ The function is nowhere assigned to special officials in a private society; in LSCG 58, 1.12-14 it is merely one of the responsibilities of a foundation's $\dot{\varepsilon} \pi \mu \varepsilon \lambda \eta \tau \alpha$. The most interesting parallel is perhaps Pausanias 10.32.14: before the biannual festival of Isis at Tithorea, the adyton is purified 'in a secret fashion' by individuals picked out for the task by the goddess herself through dreams.

In the cleansing on Itonios 13 (A 4-8) the porßatpíal are or may be dealing with physical dirt, and the words listed above usually refer to cleansing with liquids; but in

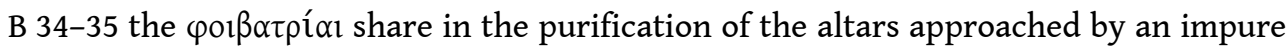
person. In A 23, if they are correctly read there, they either eat, or dispose of, a victim; in B 20-21 they are charged with collecting for the goddess. They seem to have assisted the priestess in a broad range of ways. 
84 (b) Periods of exclusion for those in impure conditions. B 26-35 treats the topic. It prescribes 'A woman shall enter from childbirth on the thirtieth day, she who miscarries/aborts on the fortieth day, from a man after washing from the head down, from the processes of nature (i.e. menstruation) on the seventh day. If anyone enters without having observed purity ( $\dot{\alpha} \gamma v \varepsilon u ́ \sigma \alpha \varsigma$, masculine) from the things aforementioned ...' (a ritual of purification is then prescribed). The section appears to intrude within rules for sacrifice. Comparable restrictions for men do not survive, though they must have existed; on the three day rule of B 9-10 see (e) below. Had such preceded, $\dot{\alpha} \gamma v \varepsilon v ́ \sigma \alpha \varsigma$ covering both genders would have been normal; as the text stands it is bizarre, and one may suspect that $\dot{\alpha} \gamma v \varepsilon v ́ \sigma \alpha \sigma \alpha$ should have been written. ${ }^{209}$ The pollutions listed are specifically feminine; it is surprising that there is no reference to contact with death, but this pollution may have been omitted because common to both genders.

Though regulations of this kind are familiar, the details would surprise at this date in a traditional Greek cult. An exclusion for 30 days after childbirth is the longest so far attested; 10 days was probably the norm, ${ }^{210}$ and even the late LSS 91, 1.15 (third

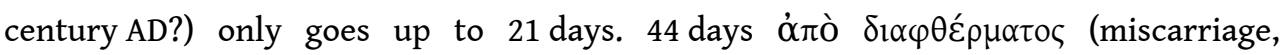
abortion) is attested in a cult of Egyptian gods at Megalopolis c. $200 \mathrm{BC},{ }^{211} 40$ days in the sanctuary of the Syrian gods on Delos in the second/ early first century $\mathrm{BC}^{212}$ and in unidentified sanctuaries at Ptolemais in Egypt in (?) the first century $\mathrm{BC}^{213}$ and perhaps at Eresos on Lesbos. ${ }^{214}$ But the securely identifiable cults in this list are non-Greek; in the earlier evidence from Greek cults miscarriage pollutes like either death or birth, thus in neither case for as long as 40 days. ${ }^{215}$. Particularly clear is the rule on menstruation, which pollutes in the cults of the Egyptian gods at Megalopolis, the Syrian gods on Delos, and the unknown cult at Ptolemais mentioned above, ${ }^{216}$ and much later in Xanthos' foundation for Mên in Attica, ${ }^{217}$ but is a surprising absentee from cults honouring old Greek gods. ${ }^{218}$ The relaxed attitude to sexual pollution - immediate access after washing - is perhaps more typical of Greek than non-Greek cults, but not unknown in the latter: the Megalopolis law has the same modest requirement as here. 219

86 (c) Purification in preparation for initiation. Lines A 18-23 appear as follows in the first

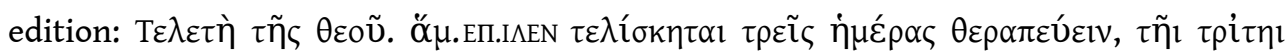

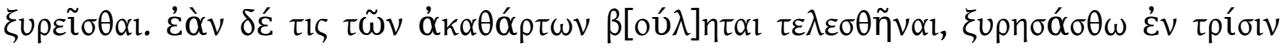

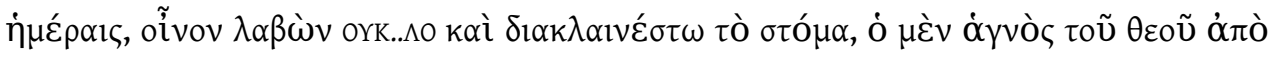

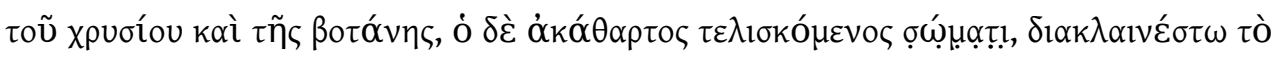

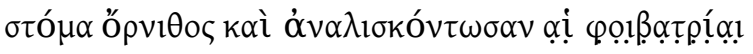

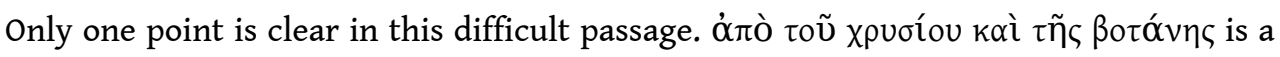

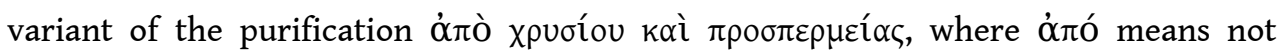
'from' but 'by means of ', ${ }^{220}$ attested on $\mathrm{Cos}^{221}$ this is the clearest trace in the text of a possible connection between Thessaly and $\operatorname{Cos}^{222}$ Insoluble problems surround it:

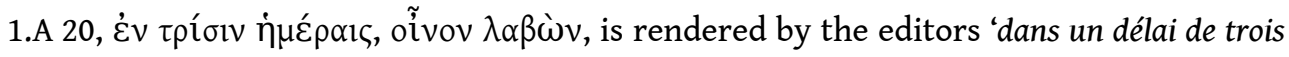
jours après avoir pris $d u$ vin'. If this means 'after three days abstinence from wine' it is paralleled by occasional requirements to approach Egyptian gods 'pure from wine'223 but strains the Greek, which should mean 'within three days, having taken wine'. ${ }^{224}$ Wine had ritual uses in Egypt, ${ }^{225}$ and it is not certain that abstention from it is what is here being enjoined. But we need to be told 'within three days' from what starting point. 
2.The verb $\delta 1 \alpha k \lambda \alpha$ ívelv is unknown, and a guess at its meaning is made very difficult by

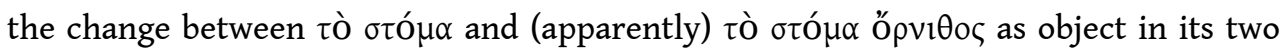
occurrences. The editors show their perplexity by offering different tentative translations in the two cases. For the first they offer 'garde bouche close (?)', probably assuming a variant form of $\delta 1 \alpha \kappa \lambda \varepsilon i \omega$, but this gives bad sense; one cannot keep the mouth closed indefinitely. The second they render 'qu'il brise le cou d'un oiseau (?)', probably thinking of $\delta ı \alpha k \lambda \alpha$ ó $\omega$. That interpretation gives possible sense there, since birds were often killed through the mouth, ${ }^{226}$ but is impossible in the first occurrence; and the middle form is not justified. The obvious meaning required by context in the first instance is 'cleanse', and Andreas Willi has tentatively suggested a route by which

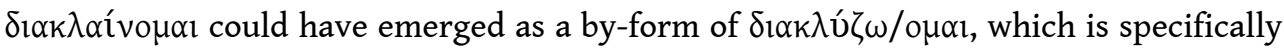
used of the mouth in Hippocrates and Aristotle (see LSJ s.v.). ${ }^{227}$ To give it that sense in the second occurrence we must remove the comma before the second $\delta_{\imath \alpha \kappa} \lambda \alpha \imath v \varepsilon \dot{\sigma} \tau \omega$,

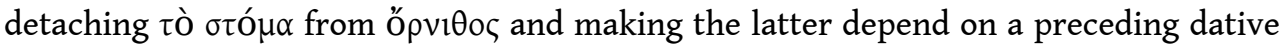
of instrument, whether the editors' $\sigma \omega \omega_{\mu \alpha \tau \iota}$ (all letters dotted) or our very tentative

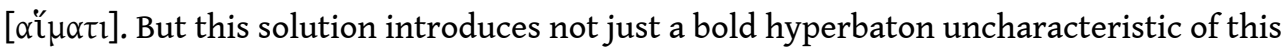

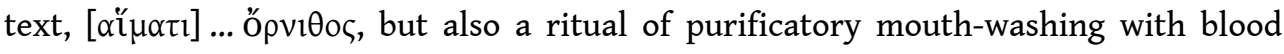
that is unattested and not readily believable.

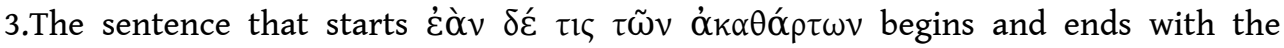

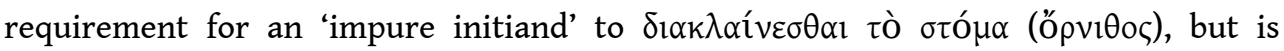
interrupted by a clause concerning the 'pure one of the god'. This is inconsequential on any view. The inconsequentiality is lessened if 'the pure one' is also required

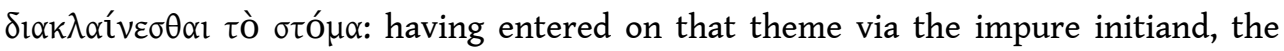
writer would then have digressed to specify the different method by which the pure one was required to 'cleanse his mouth' (if that is indeed what the phrase means). The probably fatal difficulty with that view is that the purification 'by gold and plant' is normally, and surely rightly, taken to entail sprinkling, not drinking; ${ }^{228}$ it does not then involve the mouth. We must then suppose that the writer has veered to the quite different means by which the pure one purified himself. Such inconsequentiality is common in speech, strange in writing.

The difficulties noted under (2) and (3) could be alleviated by the hypothesis - but we are now piling speculation on speculation! -that the phrase 'purify the mouth' had become fossilized to mean simply 'purify oneself' without any reference to the mouth; 229 this would dispense with the blood drinking of (2) and allow the purification 'by gold and plant' of (3) to work normally; there would remain the hard hyperbaton of (e.g.)

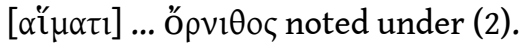

89 (d) On the ritual aspects of the three purifications, and the sacrifices that must follow them, after pollution of parts of the sanctuary see p. 239-241. By contrast, a phoibatria who neglects a duty must pay for a sacrifice, but has not polluted the sanctuary (B 2021 ), and an initiand who prefers not to shave can apparently buy himself free of the obligation (A 27). In B 2-6 and in B 29-35 it is specified that the purification is performed by members of the temple staff (just as they are charged with purifying 'impurities in the sanctuary' in A 6-8); thus 'let him purify' in B 30 must be imprecise for 'let him pay for the purificatory offering'. The same is likely to have applied in B 1316 too. Whether the offender performed his own sacrifice, or whether this was seen as part of the purification performed by the temple staff, is unclear, though one might 
think that the offender against time-based purity rules of B 29-35 should not have been allowed to sacrifice until the required time had passed.

(e) B 7-10 prescribes 'An uninitiated person shall not go into the prothyron, unless any wishes to perform a vow ... and keeps pure for the three days from all the things specified above.' No such 'three day' rule is found in the surviving portion of the text. Among the conditions or activities purity from which is commonly required in sacred laws, several are treated later in the text ([b] above), where the 'quarantine' period tends to be much longer than three days. It is likely then that the reference here is to something different; very probably what was required was abstention from particular foods for a period before approaching the sanctuary, as in the Egyptian cult at Megalopolis and the Syrian cult on Delos from which parallels to our text were quoted above. $^{230}$

\section{General character of the text}

91 That the cult performed at the unknown sanctuary for the unknown goddess is a hybrid has been obvious from the start. On the Greek side, there is nothing un-Greek about the titles of the cult personnel; the porßatpí $\alpha$ are new, but they bear a Greek name and perform functions familiar from Greek cult. 'Collecting' is already attested in the cult of Greek goddesses in the fifth century. ${ }^{231}$ The physical features of the sanctuary bear familiar Greek names, though this does not prove that they had familiar Greek forms. ${ }^{232}$ On the other hand, the two festivals, thus the central activity with which the text is concerned, bear names derived from 'the standard Mesopotamian calendar'; the long duration of the Eloulaia ( 7 days, preceded by collecting) finds many parallels in the ancient Near East, ${ }^{233}$ though not unheard of in the Greek world. It is unfortunate that we learn no more about the Nisanaia than that the procession occurs 'if the goddess comes from the river'. Nisan, at the time of the spring equinox, was the first month of the year in the standard Mesopotamian calendar, and a time of major cultic activity throughout the ancient Near East; often (so for instance at Seleucid Uruk) it hosted an 'akitu' festival, enacted over many days and centring on the withdrawal and triumphant return of a deity. It is tempting to imagine the 'coming of the goddess from the river' within such a scenario; but we know too little to press the comparison. ${ }^{234}$ It is tempting too to wonder whether the festivals at Marmarini retain a calendrical/ astronomical connection: the Nisanaia were probably close to the spring equinox; Elul is the fifth month after Nisan, and the Eloulaia reached their climax in the second half of the Thessalian equivalent to Elul (itself the first month of the Thessalian year, marked by collections at the new moon [B 17-18]), on Itonios 17, thus close to the autumn equinox if not exactly coincident with it. ${ }^{235}$

The gods named are a mixture of Greek and non-Greek, but 'the goddess' herself, we believe, is not the Greek Artemis Phylake. The entry requirements after pollutions find their detailed parallels at this date in the cults of Egyptian or Syrian gods practised on Greek soil. Central aspects of the cult's sacrificial regime such as the frequency of bird victims and of holocaust sacrifices, and many of its salient anomalies by the standard of Greek norms, are very probably to be explained by hybridity. The non-Greek components have themselves multiple origins: Semitic and Anatolian ${ }^{236}$ elements are certain, and it is at least possible that Egyptian cults have also contributed. What one is to make of 'initiation' is the most tantalising question: as a form of cultic action it is 
unquestionably Greek, but is it exclusively so? At all events candidates for it are now invited to submit to the drastically non-Greek requirement to shave the head - but may be able to avoid it.

93 A completely clear picture does not emerge from the various restrictions on offering particular victims to particular gods. The rule that one may bring anything except fish and doves to 'Pan whom the Syrians call [...] PLEN') (A 9-11) recalls the Syrian reverence for fish and doves already mentioned by Xenophon. ${ }^{237}$ Doves are not mentioned again, whether positively (amid the many bird species that appear as permitted victims) or

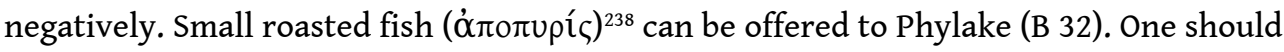
not then stress too much the Syrian character of the text, since the familiar restriction on fish is limited to one case, and even there the ban is on offering, not eating, the species. Pork is the offering most regularly forbidden in the text (through strangely not in relation to 'Pan whom the Syrians call [...] PLEN'): it is never permitted and repeatedly banned (B 15, 32-33, 51), even in the prescription for 'sacrifice by the Greek rite' (B 36); purifications are performed with birds, not, as normally in Greece (except for Aphrodite), ${ }^{239}$ with piglets. But twice the worshipper is permitted to sacrifice 'anything he pleases' (A 16-17, to Lillaias and Artemis Phylake and Apollo? Pylaios; B 44, a rather mysterious context); one may wonder whether the complete freedom implied by that formula was really intended. The editors write ${ }^{240}$ that the ban on pork does not in itself allow one to speak of a cult as oriental; but in Greece it is confined to Aphrodite and (this only so far on Thasos) figures from her entourage. ${ }^{241}$

It is not easy to contextualize in Thessaly the immigrants (or returning soldiers?) who introduced the cult. Demetrias was a cosmopolitan city, but the easterners whose specific origin is attested by the famous painted gravestones are, almost without exception, Phoenicians, and Phoenicia was one region of the Near East where the standard Mesopotamian calendar, from which come the festival names Eloulaia and Nisanaia, was not in use. ${ }^{242}$ Philip V in $217 \mathrm{BC}$ famously exhorted the citizens of Larisa to share their citizenship more generously, like the Romans, ${ }^{243}$ but there is no knowing the origin of the beneficiaries he envisaged; they may well have been primarily metics from other Thessalian cities. Much the most suggestive document for our purposes is a base from Krannon, tentatively dated to the late second century $\mathrm{BC}$, which bears a dedication plausibly supplemented by the editor $\Pi \alpha \rho \theta[\varepsilon ́ v \omega t ?] / B \alpha \mu \beta v \kappa i ́[\alpha 1$ ?]/

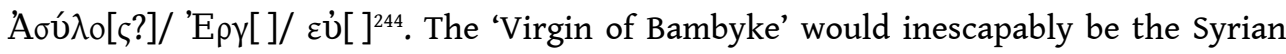
goddess, Atargatis of Hierapolis/Bambyke, even if that precise periphrasis for her is not found elsewhere; and it would become arguable that a Parthenos who receives a dedication at Pherai in the third century was the same goddess (though she may rather be a quite distinct Parthenos widely attested in Northern Greece). ${ }^{245}$ The Syrian goddess already had public cult at Beroia in Macedonia in the third century BC. ${ }^{246}$ 'The goddess' of our inscription might indeed be Atargatis - but one misses any reference to her well-known consort Hadad.

The great absentees from our picture of the cult are the worshippers. Since no single individual is named, we have no information about their ethnicity; the Eloulaia and Nisanaia were surely brought to Thessaly by immigrants, but numerous examples show how imported cults could be swiftly domesticated. Carbon has stressed the permissive character of the text, with its openness to sacrifice in many forms, whether Greek or an unidentified other. Against this must be set the requirement for male initiates to join what Juvenal was later to call a 'grex calvus'; ${ }^{247}$ but we saw above that even this may 
have been avoidable for a small fee. There may also have been a recommendation (unenforceable) of abstention from certain foods for three days before entry. ${ }^{248}$

The editors and Carbon have discussed the body responsible for publishing the rules and thus in charge of the sanctuary; both, with due caution, have inclined towards a private body rather than the city. Parallels can certainly be drawn with the activities of some of the associations of the Hellenistic period. ${ }^{249}$ Associations could have 'temples' and other elaborate architectural features, ${ }^{250}$ celebrate named festivals, ${ }^{251}$ and organise processions and collections. ${ }^{252}$ Yet our text is very unlike any surviving decree of an association. The difference is not just that such decrees relate almost exclusively to honours and membership and not to the actual rituals that are to be performed. More important is the complete absence from our text of the characteristic officials of such

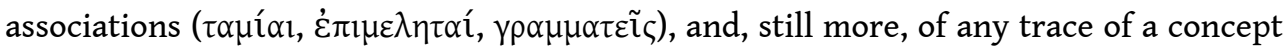
of association or membership. Even if we suppose that the concept of member has been replaced by that of 'initiate', the openness of the sanctuary to non-members/initiates is

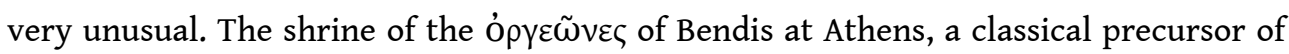
the later associations, was open to non-members, ${ }^{253}$ but these ó $p \varepsilon \varepsilon \tilde{\omega} v \varepsilon \zeta$ were a most unusual case, since both they and their sanctuary had a role in a civic festival. And even the Bendis ó $ү ү \varepsilon \tilde{\omega} v \varepsilon \varsigma$ charged special fees to non-members who sacrificed in the shrine: our text, preoccupied though it is with perquisites and fees, makes no such distinction. It is true that we do not know how the cult of some non-Greek gods was organised in the early years after their introduction: the cults introduced to Athens by the merchants of Kition (Aphrodite) and 'the Egyptians' (Isis) are cases in point, as is that of Sarapis brought to Delos by Apollonios. ${ }^{254}$ But a contribution-paying association is the most likely answer. Until a sanctuary of some importance (minor rustic shrines are a different case) has been identified that is both private and open to 'anyone who wishes', the Marmarini precinct will be isolated if so understood.

The alternative is that it was controlled by a city. It may be objected that no set of rules issued in the name of a city resembles our text any more than did decrees of private associations. But it is at least possible to imagine situations in which a city might have created such a text. Gods initially worshipped by associations of foreigners were adopted into the civic pantheon of cities; or perhaps cities decided of their own accord to introduce such cults. We know no study devoted specifically to the take up by cities of foreign gods, but it was certainly commonplace: in regard to Egyptian gods we can mention public priesthoods attested by the end of the second century BC in Thessalonike, Delos, Athens, Demetrias, Magnesia on the Maeander, and Priene, and, if we accept the evidence of manumissions by consecration, public cult in numerous cities of central and northern Greece; ${ }^{255}$ in regard to the Syrian goddess, public cults in the hellenistic period on Delos, at Thuria in Messenia, Beroia in Macedonia, and probably Phystion in Aetolia. ${ }^{256} \mathrm{~A}$ civic sanctuary might be established alongside and to some extent in rivalry with one belonging to an association or associations, as happened when Sarapieion C joined the private Sarapieia A and B on Delos; or an association's sanctuary might simply be taken over, as with that of the Syrian goddess on Delos. The documents that attest these cults reveal little about the ritual activities that took place in them, but numerous dedications show the popularity of both Sarapieion C and the Syrian sanctuary; festivals have certainly to be supposed. ${ }^{257}$ We have already noted the theatre in the Syrian sanctuary, the 'mysteries' of the same cult at Thuria in Messenia. Different religious traditions came together in Sarapieion $C$ as in the Marmarini 
sanctuary; Roussel, observing the range of deities who received dedications, famously described it as a pandemonium. ${ }^{258}$ Rural Thessaly is a very different environment from multi-cultural Delos, but the hybridity of the Marmarini cult is a fact.

It has been objected to us that an imported cult taken over by a city would not bear the aspect that this one does: the city would have replaced the libertarian approach of the text with sacrificial norms, and would not have cared to accommodate the worship of obscure gods with unadjusted barbarian names such as Mogga and Lilla(ias). ${ }^{259}$ These points have force, but are not decisive when we know so little in detail of the processes and stages by which cities incorporated imported cults. Any confident statement about so unusual a text is hazardous, but we tentatively assign it to a city, thus presumably Larisa. On any view, the new document is a bombshell that has transformed our sense of the possibilities of middle/late Hellenistic religion.

\section{Abbreviations}

\begin{tabular}{|l|l|}
\hline CIS & Corpus Inscriptionum Semiticarum. \\
\hline LSAM & F. SOKOLOWSKI, Lois sacrées de l'Asie Mineure, Paris, 1955. \\
\hline LSS & ID., Lois sacrées des cites grecques. Supplément, Paris, 1962. \\
\hline LSCG & ID., Lois sacrées des cites grecques, Paris, 1969. \\
\hline NGSL & E. LUPU, Greek Sacred Law: a Collection of New Documents, Leiden, 2004. \\
\hline RICIS & L. BRICAULT, Recueil des inscriptions concernant les cultes isiaques, 2 vols., Paris, 2005. \\
\hline $\begin{array}{l}\text { I.Priene } \\
(2014)\end{array}$ & $\begin{array}{l}\text { W. BLÜMEL and R. MERKELBACH, Die Inschriften von Priene, Bonn, 2014 (Inschriften von } \\
\text { Kleinasien, 69). }\end{array}$ \\
\hline
\end{tabular}

\section{NOTES}

1. .J.C. DECOURT, A. TZIAPHALIAS, "Un règlement religieux de la région de Larissa : cultes grecs et 'orientaux'," Kernos 28 (2015), p. 13-51.

2. See J.M. CARBon, "The Festival of the Aloulaia, and the Association of the Alouliastai: Notes Concerning the New Inscription from Larissa/Marmarini”, Kernos 29 (2016), p. 185-208, at p. 186, n. 1.

3. See p. 218 below.

4. .A $\tau \varepsilon \lambda \varepsilon \tau \eta ́$ can be a rite of any kind, not necessarily an initiation: see F.L. SCHUDDEBOOM, Greek Religious Terminology - Telete \& Orgia. A Revised and Expanded English Edition of the Studies by Zijderveld and Van der Burg, Leiden, 2009. But what follows determines the sense here. 
5. .Carbon, o.c. (n. 2), n. 12, raises the interesting possibility that 'the three days' refers to the three days preparatory to the Eloulaia mentioned elsewhere in the text. But 'all the things specified above' still lacks a referent.

6. o.c. (n. 2), p. 188-189.

7. Ten if we include those of the $19^{\text {th }}$. CARBON, o.c. (n. 2), p. 192-193, 197-198, supposes that the Nisanaia preceded the Aloulaia on side A, this being the order of the two months in question in the Mesopotamian calendar. But since Itonios (=Elul) was the first month of the Thessalian year, a reverse order is possible.

8. .The reference cannot be to either of the other purifications, of the vóo that are prescribed in B 1-16, if we are right to argue below, p. 219, that the peristyle was not attached to the temple.

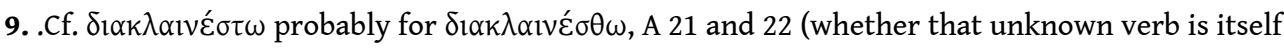
a local variant is unknown); $\mu \varepsilon \tau \grave{\alpha} \tau \tilde{\alpha} \varsigma$ i $\varepsilon \rho \varepsilon i ́ \alpha \varsigma$ A 6-7.

10. DECOURT - TZIAPHALIAS, o.c. (n. 1), p. 37, cf. 15.

11. o.c. (n. 2).

12. On the festivals celebrated in Nisan (first month of the year) throughout most of the Ancient Near East see D. SOURDEL, Les Cultes du Hauran à l'époque romaine, Paris, 1952, p. 109-110 (who stresses the frequency of holocausts); M.E. COHEN, Festivals and Calendars of the Ancient Near East, Bethesda, 2015, p. 387-408.

13. .On Adar see CARBON, o.c. (n. 2), n. 17.

14. To his single attestation, o.c. (n. 2), p. 202, for the possibly theophoric name Alulaios (LGPN 1, Delos, $3^{\text {rd }}$ c. BC) add Aloulaios, IGLS II 449 (Antioch), to which Sofia Kravaritou refers us.

15. o.c. (n. 2), p. 191-192.

16. See Carbon, o.c. (n. 2), p. 187, n. 3, who has seen more punctuation marks than the editors.

17. The Greek of this section is difficult. $\pi \lambda u ́ v \tau \eta \theta 1 . . . v \alpha o$ vo: the form is probably the $2^{\text {nd }}$ person passive imperative of $\pi \lambda \dot{v} v \omega$ (Attic $\pi \lambda \dot{v} v \theta \eta \tau \iota$ ), with the first rather than second aspirated consonant of underlying $\pi \lambda u ́ v \theta \eta \theta_{r}$ dissimilated, but the person is inappropriate, as is the following accusative object. $\kappa \alpha \theta \alpha \rho i ́ \sigma \theta \omega . . . \tau \grave{\alpha} \varsigma$ $\varphi \circ \beta \alpha \tau \rho i ́ \alpha \varsigma: ~ \kappa \alpha \theta \alpha \rho i ́(\zeta \varepsilon) \sigma \theta \omega$ would be a $3^{\text {rd }}$ person singular passive imperative, 'let the impurities be purified', but the construction continues as if

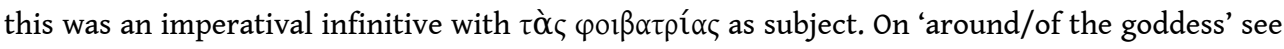
p. 218.

18. .CARBON, o.c. (n. 2), p. 197, n. 25, prefers to translate 'kettle-drums'.

19. We follow the editors' rendering 'lors de la cérémonie nocturne' for the unparallelled $\tau \tilde{\eta}_{1}$

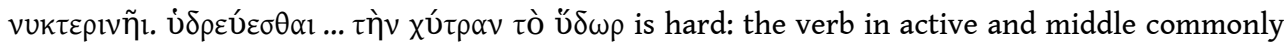
means 'draw water' with no object expressed. Here it seems to be constructed with two accusatives in the sense of 'fill'.

20. .So the editors: 'jeter (ou déposer?)'.

21. On this problematic passage see p. 258-260.

22. .Here and in A 34 LSJ sense III 'consume' of ó $v \alpha \lambda i ́ \sigma k \omega$ is likely: cf. p. 253-254. 'Dépensent (?)' the editors.

23. The editors render 'de la vigne consacrée', which is not supported by the text they print. Lagana: a kind of unleavened flat bread (cf. n. 165).

24. .On бxoĩvoৎ see n. 142 below.

25. .On this new form i $\lambda \alpha \tau \eta \rho i ́ \alpha$ see DECOURT - TZIAFALIAS, o.c. (n. 1), p. 45, n. 114.

26. .Homora : a kind of sweet bread (cf. n. 165).

27. The stone gives 'a stater for the mixing-bowl (krater)', which can only be explained by a complicated hypothesis (cash in lieu of the offering in kind); we suspect the cutter substituted one word much used in this text for another (e.g. B 67), misled also by the rhyme.

28. o.c. (n. 2), p. 188-189. 


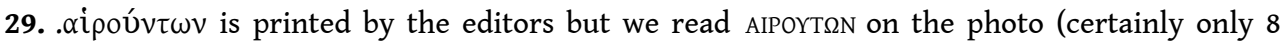
letters) and prefer the correction $\alpha i \rho o ́ v \tau \omega \nu$.

30. .Sense unclear.

31. Whether the interlinear addendum corrects the date or adds a new collecting period is unclear. The editors articulate differently, to give as a new sentence 'unless one proclaims within three days in advance, collect on the tenth until the twelfth of (the) month'. But the 'unless' clause lacks a connective and should look back; the 'collect on the tenth' clause has one and so should not be the apodosis of a conditional. 'Announce three days in advance' would normally require a dative; here we have the genitive $\tau \rho i \tilde{\omega} v \dot{\eta} \mu \varepsilon \rho \tilde{\omega} v$, but no other translation seems possible.

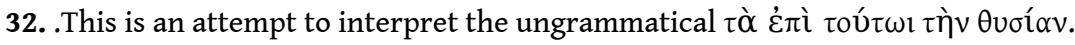

33. We are uncertain whether the 'inscription for the peristyle' ends here, as the marginal paragraphos may suggest, or continues down to 26 or even (but this would give a very long notice on the peristyle) 35 .

34. On this probably mistaken masculine see n. 209.

35. Mysterious: sanctuary wines are not otherwise known.

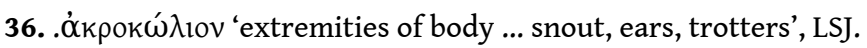

37. .Literally, 'the leg from the breast'.

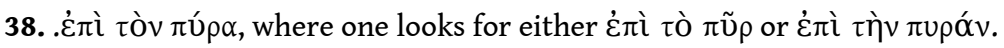

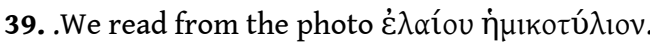

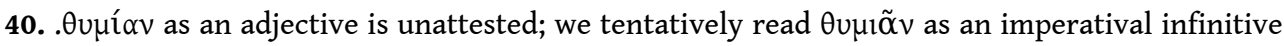
from $\theta u \mu \imath$ ó $\omega$; the odd word order can perhaps be explained if only the incense and myrrh are objects of this verb.

41. DECOURT - TZIAPHALIAS, o.c. (n. 1), p. 42, take $\beta \alpha \sigma l \sigma \alpha \beta \alpha \rho \rho u \tau \alpha$ as a twice repeated misspelling for

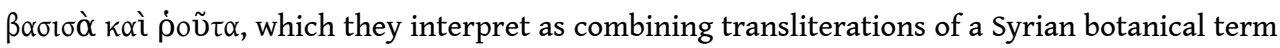

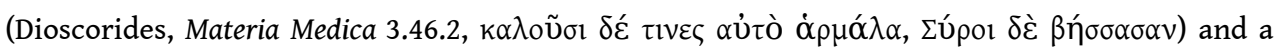
Latin, ruta, rue. A Syriac term bashasha, bashosha with an Aramaic equivalent is well attested

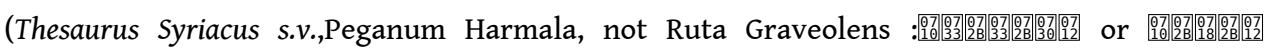
according to I. Löw, Aramceische Pflanzennamen, Leipzig/Berlin, 1881, p. 370-372, no. 317), but the

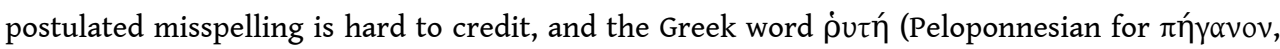
according to Iolaos, On Peloponnesian Cities, cited in $\Sigma$ Nicander, Theriaka, 523) is also relevant.

42. .Unknown.

43. .Unlike the editors, we take all these three prohibitions to apply to the uninitiated; they take the two latter to be general. See p. 220-221.

44. I.e. on our interpretation 'any uninitiated person'.

45. .The articulation of these clauses is problematic: the editors render 'nor bring the egg of another species, if anyone sacrifices a hen to the goddess at the altar of Moira; and let anyone who wishes go to the altar of Moira and Helios.'

46. On this problematic back reference see p. 211.

47. The editors render 'selon la prescription concernant le péribole', i.e. another back reference to an unidentifiable earlier regulation. This is possible, but our rendering better suits the normal sense of $\pi \rho \circ \rho \alpha \varphi \eta ́$.

48. But Edouard Chiricat has pointed out to us a plausible connection between this theonym and the several probably theophoric anthroponyms in Movy- attested in Rough Cilicia: LGPN V B (2013), p. 302.

49. .See R. PARKER, “The Nameless Goddess of Marmarini”, ZPE 199 (2016), p. 58-59.

50. .A 3, 14, 25; B 3, 76, 77 (the altar is mentioned in the last three references).

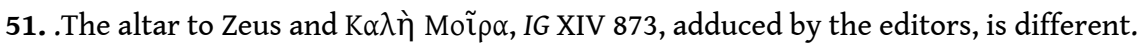

52. SEG 42, 535; much later, an altar of Moirai at Metropolis, IG IX 2, 282. 
53. As suggested to us by Sofia Kravaritou.

54. .On whom see e.g. S. RIBICHINI, s.v. "Gad", in K. VAN DER TOORN et al. (eds.), Dictionary of Deities and Demons in the Bible, Leiden, $1999^{2}$ [1995], p. 339-341.

55. On all these see the relevant entries in M.C. HELLMANN, Recherches sur le vocabulaire de

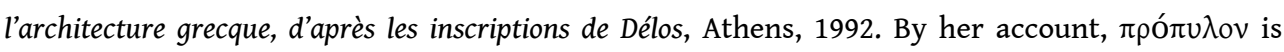

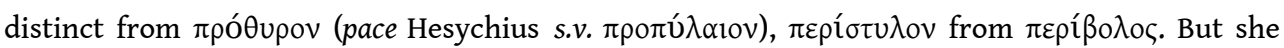
may be seeking too much precision; for imprecision Coulton refers us e.g. to J.-C. MORETTI, C. MAUDUIT, "The Greek Vocabulary of Theatrical Architecture", in R. FREDERIKSEN, E. GEBHARD, A. SокоLICEK (eds.) The Architecture of the Ancient Greek Theatre, 2015 (Monographs of the Danish Institute at Athens, 17), p. $119-129$.

56. .See DECOURT - TZIAPHALIAS, o.c. (n. 1), p. 23-25.

57. .D. LANGSLOW, "The Language of Polybius since Foucault and Dubuisson", in C. SMITH, L.M. YARROW (eds.), Imperialism, Cultural Politics and Polybius, Oxford, 2012, p. 85-110, at p. 93.

58. .Altars were anointed with oil, sprinkled or smeared with ash, and whitewashed, apparently without scrubbing off accumulations of blood: see IG II $^{2}$ 1672, 140-141 (Eleusis, altar of Plouton and altar of the goddesses, 329/8 BC); IG II ${ }^{2}$ 659, 24-25 (Athens, altar of Aphrodite Pandemos, 287/6 BC); Paus. 5.13.11 (altar of Zeus at Olympia annually smeared with a mixture of ash from the prytaneion and water from the Alpheus); cf. M.P. NILSSON, Geschichte der griechischen Religion, I, Munich, $1967^{3}$ [1941], p. 151. That sort of treatment of an altar will not be implied by $\pi \lambda$ úvalv at A

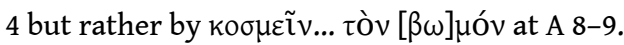

59. .See e.g. Aristophanes, Wasps, 394; Wealth, 1184.

60. .For such a possibility cf. mutatis mutandis the description of the four porticus of the Herodian temple, of which the inner three progressively excluded non-Jews, women, non-priests, in Josephus, Against Apion II, 103-104. We have wondered whether the odd positioning of the rules on female impurities (B 26-29) straight after the requirement for preliminary sacrifices might imply that women could not proceed beyond the stage of preliminary sacrifice at altars not in the heart of the sanctuary. But so important a limitation ought to have been made explicit.

61. .Unlike DECOURT - TZIAPHALIAS, o.c. (n. 1), p. 23, who print a single sentence and take $\mu$ ń $\delta$ '

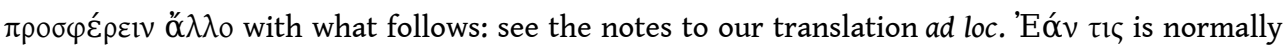
sentence-initial in this text, usually with $\delta \varepsilon \dot{~ b u t ~ w i t h o u t ~ i t ~ a l s o ~ a t ~ B ~ 49, ~} 73$.

62. We assume that the verb in the protasis of this sentence is to be understood in the first

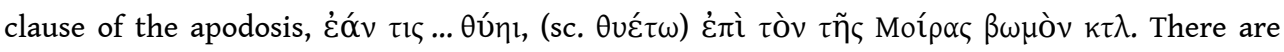

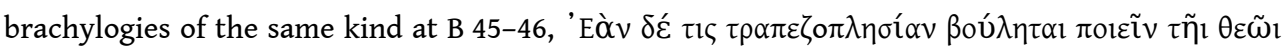

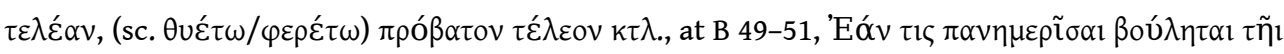

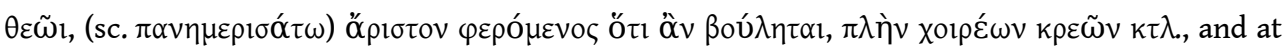

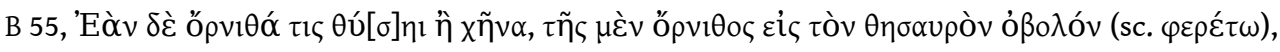

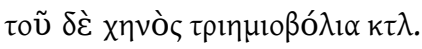

63. .Ath. 9.373 e-374 d illustrates with many examples use of the cognate word $\alpha \lambda \varepsilon \varepsilon \kappa \rho \nu \omega ́ v$ of both male and female chickens; see also Ar. Nub. 660-667.

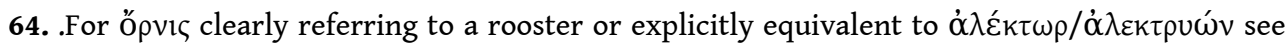

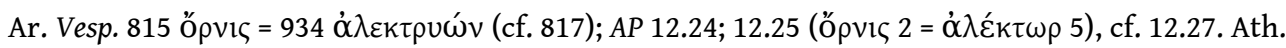
$9.373 \mathrm{a}-\mathrm{c}$ notes post-classical application of ópvis to female chickens in particular.

65. .Asclepius: Pl. Ph. 118 a 7-8; Artem. Oneir. 5.9; Herodas, 4.11-18. Suda $\beta 457$ (ed. ADLER) s.v.

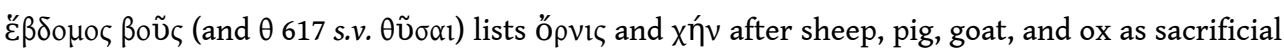

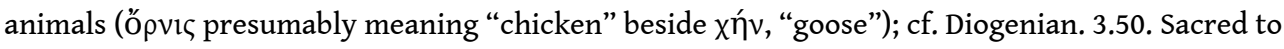
Apollo/Helios: Plut. Pyth. orac. 400 c; Paus. 5.25.9; Ael. fr. 186. Sacrificed to Apollo: AP 6.155; 12.24; to Moon and Sun: Iambl. Protr. 21.17; to Ares: Plut. Apoth. Lac. 238 f; to Anubis: Plut. Is et Os. 375 e. 66. .D.S. REESE, "Faunal Remains from the Altar of Aphrodite Ourania, Athens", Hesperia 58 (1989), p. 63-70, at p. 69 observed that "burnt bird bones are very rarely found on altars or in 
sanctuaries", and this still holds; they occur only very occasionally, e.g., among the "documents archéozoologiques" assembled by A. HERMARY and M. LEGUILLOUX, "Les sacrifices dans le monde grec", in ThesCRA I (2004), p. 59-134. On birds and e.g. incense as poorer offerings cf. Kynno's offering of a cock as "dessert course" ( $\tau \dot{\alpha} \pi \hat{i} \delta o \rho \pi \alpha)$ at Herodas, 4.11-18, with the implication confirmed by explicit contrast with "an ox or a piglet with plenty of crackling" - that the cock is not the sort of offering to constitute the main course. There is a useful compilation of parallel evidence in W. HEAdLAM, A.D. KNOX, Herodas: The Mimes and Fragments, Cambridge, 1922, p. 179-80, at p.180. Lucian's Zeus Tragôidos says that stingy Mnesitheus entertained sixteen gods by sacrificing "only an $\dot{\alpha} \lambda \varepsilon \kappa \tau \rho \nu \omega ́ v$ " and some incense (JTr. 15), and in On Sacrifices Lucian says that,

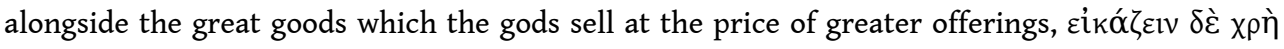

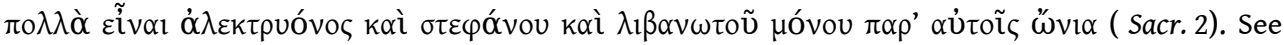

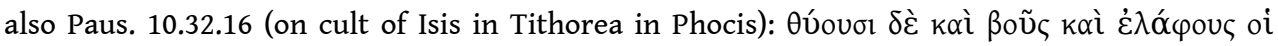

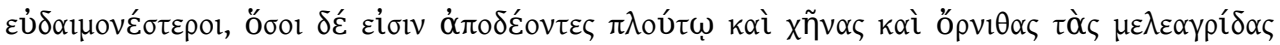
("guinea-fowl"?); Plut. Apoth. Lac. 238f and Marc. 22, where the Spartans are said to encourage their leaders to be strategic by sacrificing a ßoṽ if they have defeated an enemy by stratagem but merely an $\dot{\alpha} \lambda \varepsilon \kappa \tau \rho \nu \omega \omega v$ if by open conflict. Pausanias (2.11.7) reports that in the Asklepieion at

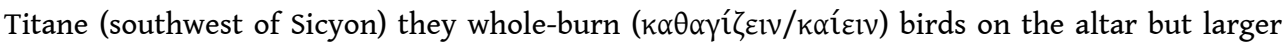
animals on the ground. This presumably has to do with the sufficiency of an altar fire for the holocaust of a bird rather than with the comparative prestige of birds and larger animals as offerings; for a more venturesome interpretation of the distinction see V. PIRENNE-DELFORGE, Retour à la source. Pausanias et la religion grecque, Liège, 2008 (Kernos, suppl. 20), p. 193-197.

67. .Leviticus chapters 1-2; Lucian, Syr.D. 54. The Punic sacrificial tariffs, both probably from Carthage (though the first was found in Marseilles), are late $4^{\text {th }}$ or early $3^{\text {rd }} \mathrm{c}$. BC. The first, CIS I $165=$ H. DONNER, W. RÖLLIG (eds.), Kanaanäische und Aramäische Inschriften, Wiesbaden, 2002 ${ }^{5}$, no. $69=$ NGSL, Appendix A, p. 391-396 with English translation (also translated by D. PARDEE, "A Punic Sacrificial Tariff", in W.W. HALlo (ed.), The Context of Scripture I, Leiden, 1997, p. 305-309) deals in turn with offerings of a mature bovine (lines 3-4); an immature bovine or a mature deer (5-6); a mature sheep or goat (7-8); an immature sheep, goat, or deer (9-10); "a fowl or a free-flying bird" (11); other birds (12); there follow clauses regulating perquisites (13-21), including the exemption of the poor from fees and perquisites mentioned in the text (15). The second text, CIS I 167 = DONNER - RÖLLIG, ibid., no. 74 (English translation by Fr. ROSENTHAL in J.B. PRITCHARD (ed.), Ancient Near Eastern Texts Relating to the Old Testament, Princeton, $1969^{3}$, p. 657) deals in turn with offerings of ox (line 2); stag? (3); ram or goat (4); lamb, kid, or? young stag? (5); offerings by the poor (6); offerings of birds (7); followed by further regulations. On the bird sacrifices in the Punic tariffs see M. DELCOR, "Le tarif dit de Marseille (CIS I, 165): Aspects du système sacrificiel punique", Semitica 38 (1990), p. 87-94, at p. 89-92.

68. .T. STAUBLI, "Hühneropfer im alten Israel: Zum Verständnis von Lev 1,14 im Kontext der antiken Kulturgeschichte", in T. RÖMER (ed.), The Books of Leviticus and Numbers, Leuven, 2008, p. 355-69, makes a strong case on a variety of grounds that Hebrew רis, tor means not “ turtledove" but "fowl" (of the phasianidae family, partridge or pheasant) in every passage in which it occurs in the Hebrew Bible except (the later) Jeremiah 8:7.

69. .Lev. 5:7-11, 12:6-8; Luke 2:22-24. Cf. J. MILGROM, Leviticus 1-16, New York, 1991 (Anchor Bible, 3), p. 166-168 on the "bird pericope" at Lev. 1:14-17 as added "to provide the poor with the means to sacrifice the burnt offering".

70. .N.S. Meshel, The "Grammar" of Sacrifice: A Generativist Study of the Israelite Sacrificial System in the Priestly Writings, with A "Grammar" of $\Sigma$, Oxford, 2014, p. 46-48, quotation 47.

71. .As noted by B.J. collins, "Animals in the Religions of Ancient Anatolia”, in B.J. collins (ed.), A History of the Animal World in the Ancient Near East, Leiden, 2002, p. 309-334, at p. 321; see V. HAAS, 
Geschichte der hethitischen Religion, Leiden, 1994, p. 658-661: "Vogelopfer sind auf die syrischen und südanatolischen Rituale beschränkt" (658).

72. .Personal burnt offerings: Lev. 1:14-17. Purification sacrifices, the so-called "sin-offering" of English bibles, Hebrew טֵַ women after childbirth); 14:22, 30 (purification of lepers); Lev. 15:14, 29 (purification from bodily discharges); Numbers 6:10 (purification of nazirites from contact with a corpse).

73. .MESHEL, o.c. (n. 70), p. 49, n. 59.

74. See the English translation of H. DANBY, The Mishnah, Oxford, 1933, p. 598-602; the tractate consists of detailed rules for the various types of bird-offering mentioned in the Hebrew Bible.

75. .O. BOROWSKI, "Animals in the Religions of Syria-Palestine", in collins (ed.), o.c. (n. 71), p. 406424 , at p. $412-413$.

76. See J. SCURLOcK, “Animal Sacrifice in Ancient Mesopotamian Religion”, in collins (ed.), o.c. (n. 71), p. 389-403, at p. 389-390.

77. .See P.A. BEAULIEU, "Egg Offerings for the Gods of Babylon", Nouvelles Assyriologiques Brèves et Utilitaires 1991.3, no.79, p.50-52. For an English translation of the Seleucid evidence see PRITCHARD, o.c. (n. 67), p. 344.

78. .See e.g. D. PARDEE, Ritual and Cult at Ugarit, Leiden, 2002, index s.v. "bird" and "goose".

79. See T. KAIZER, The Religious Life of Palmyra, Stuttgart, 2002, p. 179 with n. 45, and Plate IV.

80. .Eudoxus, fr. 284 b (ed. LASSERRE): Ath. 9.392 d-e; Diogenian. 4.49; Zen. 5.56.

81. .See Ibn al-Nadîm, Al-Fihrist 9.1 as translated in B. DODGE, The Fihrist of al-Nadîm: A Tenth-Century Survey of Muslim Culture, New York, 1970, vol. II, p. 748; cf. D. CHWoLsoHn, Die Ssabier und der Ssabismus, St Petersburg, 1856, vol. II, p. 8 (Arabic text and translation of Ibn al-Nadim), p. 84-86 n. 53, p. 87-93 n. 58-59. Al-Nadîm's source here is the great Arab Muslim philosopher Abu Yūsuf Ya'qūb ibn 'Ishāa qụ-Ṣabbāh al-Kindī of the $9^{\text {th }} \mathrm{c}$. AD. Much of our information about Harran in the Hellenistic and imperial periods comes from such late sources; see in general T. GREEN, The City of the Moon God: Religious Traditions of Harran, Leiden, 1992, especially Chapters 2 and 6.

82. .See HAAS, o.c. (n. 71), p. 665-666. Purification of lepers: Lev. 14:1-32.

83. E.N. LANE, Corpus Monumentorum Religionis Dei Menis I-IV, Leiden, 1971-1978, III, p. 101-102;

G. LABARRE, Le dieu Mèn et son sanctuaire à Antioche de Pisidie, Brussels, 2010, p. 35.

84. The testimonia have to do with the Pythagorean ban on touching or sacrificing white cocks: D.L. 8.34; Iamb. VP 84; cf. Iamb. Protr. 21. See LANE, o.c. (n. 83), III, p. 102; LABARRE, o.c. (n. 83), p. $25-$

27.

85. .See Ibn al-Nadîm, Al-Fihrist 9.1 translated DODGE, o.c. (n. 81), vol. II, p. 755-756; cf. cHWOLSOHN, o.c. (n. 81), vol. II, p. 23 (text and translation), p.181-182 n.162. Al-Nadîm attributes this information to Abu S:a id Wahb ibn Ibrahim, whom he identifies as a Christian (probably of the $9^{\text {th }}$ or $10^{\text {th }}$ C. AD).

86. .Lucian, Syr.D. 49. For holocaust at spring festivals see e.g. H. SEYRIG, "Antiquités syriennes", Syria 14 (1933), p. 238-282, at p. 277-279; D. SOURDEL, o.c. (n. 12), p. 109-110; J. LIGHTFOOT, Lucian, On the Syrian Goddess, Oxford, 2003, p. 503 with further references.

87. Deut. 33:10, 1 Sam. 7:9, Psa. 51:19.

88. See n. 67 above: CIS I 165, 1. 5, 7, 9; CIS I 167, 1. 2, 3, 4, 5. On the sacrificial practices of ancient Syria see e.g. H. GESE, M. HÖFNER, K. RUDOLPH, Die Religionen Altsyriens, Altarabiens und der Mandäer, Stuttgart, 1970, p. 174-175, 209. For interpretation of the term כלל, kll in the Punic tariffs see B.A. LEVINE, In the Presence of the Lord: A Study of Cult and Some Cultic Terms in Ancient Israel, Leiden, 1974, p. 120-122. On the shift in Hebrew terminology from kalil to 'olah see e.g. MILGROM, o.c. (n. 69), p. 173-174.

89. .See Exodus 29:38-42, Numbers 28:1-8; for the phrase, Numbers chapters 28 and 29 passim,

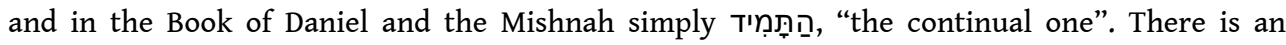
excellent brief discussion with full citation of the sources and further references in E. SCHÜRER, 
revised and edited by G. VERMES, F. MILLAR, M. BLACK, The History of the Jewish People in the Age of Jesus Christ II, Edinburgh, 1979, p. 295-308, esp. p. 299-301.

90. .DANBY, o.c. (n. 74), p. 582-589.

91. Sabbath and monthly: Numbers 28:9-15; Passover: Num. 28:16-25; Shavuoth: Num. 28:26-31; Rosh Hashanah: Num. 29:1-6; Yom Kippur: Num. 29:7-11; Sukkoth: Num. 29:12-39.

92. .See e.g. MESHEL, o.c. (n. 70), ibid.

93. Exodus 30:1-10; Mishnah tractate Yoma ("The Day of Atonement") 3, 5: DANBY, o.c. (n. 74), p. 165; Philo Judaeus, De spec. leg. 1.35 (171); 1.51 (276).

94. Jubilees $6: 3$ in the English translation of the Ethiopic text by O.S. WINTERMUTE in J.H. CHARLESWORTH (ed.), The Old Testament Pseudepigrapha, New Haven, 1983, vol. 2, p. 66.

95. .See M.J.H. LINSSEN, The Cults of Uruk and Babylon: The Temple Ritual Texts as Evidence for Hellenistic Cult Practice, Leiden, 2004, p. 165-166 (citing isolated exceptions).

96. .T. ABUSCH, "Sacrifice in Mesopotamia", in A.I. BAUMGARTEN (ed.), Sacrifice in Religious Experience, Leiden, 2002, p. 39-48, at p. 39.

97. .See HAAS, o.c. (n. 71), p. 661-662.

98. .See KAIZER, o.c. (n. 79), p. 194-195 with further references.

99. .See J.-B. YON, Inscriptions grecques et latines de la Syrie XVII, 1: Palmyre, Beirut, 2012, no. 131. The lacunose previous line of the inscription quoted - also printed and discussed by KAIZER, o.c.

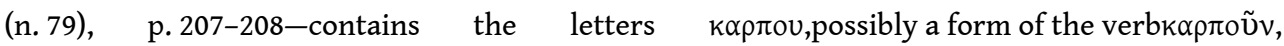
which indicates whole-burning: see LSJ s.v., P. STENGEL, Opferbräuche der Griechen, Leipzig, 1910, p. 166-168; Sokolowski, LSAM, p. 49-50 for a collection of occurrences. The other Palmyrene inscription (YON no. 381)-also printed and discussed by KAIZER, o.c. (n. 79), p. 226-226-has lineinitial ò $\lambda$ ó $\alpha u \sigma \tau o[$. "The Good Day" seems to be a festival in the month Nisan; cf. the bilingual inscription of $132 \mathrm{AD}$, YON no. 130, with KAIZER, o.c. (n. 79), p. 160 with n. 479.

100. .KAIZER, o.c. (n. 79), p. 163-164, 177-178, 195-196.

101. .Hdt. 1.183; Lucian, Syr.D. 30: see LIGHTFOot, o.c. (n. 86), p. 432-433 ad loc. with further references.

102. .See B. LEVICK, "The Table of Mên”, JHS 91 (1971), p. 80-84; LANE, o.c. (n. 83), III, p. 13-14; LABARRE, o.c. (n. 83), p. 57-58 with further references. Reliefs from Greece: LANE, o.c. (n. 83), I, p. 13 nos. 1-4, p. 6-7 no. 10.

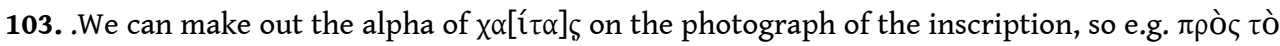

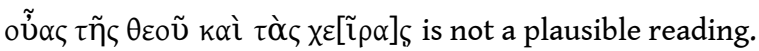

104. .T. JACOBSEN, “The Graven Image”, in P.D. MILLER, Jr., P.D. HANSON, S.D. MCBRIDE (eds.), Ancient Israelite Religion: Essays in Honor of Frank Moore Cross, Philadelphia, 1987, p. 15-32. Cf. e.g. the Babylonian temple ritual for the new year translated in PRITCHARD, o.c. (n. 67), p. 331-334.

105. Original publication, with English translation: S. SMITH, "The Babylonian Ritual for the Consecration and Induction of a Divine Statue", Journal of the Royal Asiatic Society (1925), p. 37-60 with plates II-IV; translation and discussion in E. EBELING, Tod und Leben nach den Vorstellungen der Babylonier I Teil: Texte, Berlin, 1931, no.26, p.100-108 (cf. no.27, p.108-114). More recently published texts of a later period with translation and commentary in W.R. MAYER, "Seleukidische Rituale aus Warka mit Emesal-Gebeten", Orientalia N.S. 47 (1978), p. 431-458, at p. 443-458. For purification in a river in Mesopotamian ritual see too $n .234$ below.

106. .Syr.D. 47.

107. .For a helpful discussion of the mīs pî and its various employments see V. HUROWITZ, "Isaiah's Impure Lips and Their Purification in Light of Akkadian Sources", Hebrew Union College Annual 60 (1989), p. 39-89, esp. p. 47-73; more briefly, with citation of texts and further references, LINSSEN, o.c. (n. 95), p. 153-154.

108. .EBELING, o.c. (n. 105), no. 26, lines $2,11,24,26,28-29,30-31,33-36,47,63$. 
109. .In Sumerian, Akkadian, and bilingual texts ca. 1000-700 BC: R. BORGER, "Die Weihe eines Enlil-Priesters", Bibliotheca Orientalis 30 (1973), p. 163-176; excerpts translated in W. FARBER, H.M. KÜMMEL, W.H.P. RÖMER, Texte aus der Umwelt des Alten Testaments Band II: Religiöse Texte: Rituale und Beschwörungen I, Gütersloh, 1987, p. 171-175.

110. .G. MEIER, "Die Ritualtafel der Serie 'Mundwaschung”, Archiv für Orientforschung 12 (1937), p. $40-45$.

111. .HUROWITZ, o.c. (n. 107), p. 52 with n. 34 , p. 54 with n. 41.

112. .PRITCHARD, o.c. (n. 67), p. 334-338: see p. 335 towards the bottom of the first column (bull) and of the second column (drum); this version of the ceremony was inscribed in Uruk in the Seleucid period.

113. .F. THUREAU-DANGIN, Rituels accadiens, Paris, 1921, p. 119: no. IV, "Une cérémonie nocturne dans le temple d'Anu", lines 28-30; translation in PRITCHARD, o.c. (n. 67), p. 338-339.

114. .As Andreas Willi has suggested to us it could, below n. 227.

115. .Cf. J.N. BREMMER, Initiation into the Mysteries of the Ancient World, Berlin, 2014, p. xii-xiii.

116. .See M. STAMATOPOUlou, R. PARKER, "A New Funerary Gold Leaf from Pherai", AEph (2004), p. 132 , at p. 8-9, and note the application of $\mu \varepsilon \mu u \eta \mu \varepsilon$ vo to the Samothracian Mysteries in Aristophanes, Pax, 278.

117. .Dionysos Bacch(e)ios in Olbia (Hdt. 4.79.1) and Miletus (Milet VI 3, 1222 [LSAM 48], 1. 18-20); Dionysos Thyllophoros on Cos (IG XII 4, 304, 1. 18-21, ib. 326 [LSCG 166], 1. 23-26); Dionysos in Egypt (the edict of Ptolemy [?] IV Philopator: SB 3, 7266); Mother in Priene (I.Priene [2014], 145, 1. 15-21), in Troizen (IG IV 757 B, 1. 10-11: cf. STAMATOPOULOU - PARKER, o.c. [n. 116], p. 14) and probably at Minoa on Amorgos (LSCG 103 B, 1. 11-12); the Korybantes in many places (BREMMER, o.c. [n. 115], p. 48-53); probably Demeter on Mykonos (LSCG 96, 1. 22) and perhaps in Athens (LSCG 36, 1. 3-4).

118. .LSS 120; IG XII 6, 1197.

119. .LSCG 96, 1. 20-22.

120. So W. BURKERT, Ancient Mystery Cults, Cambridge, Mass., 1987, p. 34.

121. .A.F. JAcCotTET, Choisir Dionysos. Les associations dionysiaques ou la face cachée du dionysisme, Lausanne, 2003, I, p. 143-144.

122. .On all this see JAcсотTET, o.c. (n. 121), I, p. 123-146, an excellent nuanced account; on the vocabulary of $\mu$ ó $\tau \alpha \mathrm{l}$ ('phénomène plus lexical que religieux) ibid., p. 141; cf. p. 127, n. 26 ad fin.: 'il y a de vrais mystères sans mystes, tout comme il y a des mystes sans véritables mystères'. On the weakened sense of mysteries see N. BELAYCHE, "L'évolution des formes rituelles: hymnes et mystèria", in L.BRICAULT, C. BONNET (eds.), Panthée: religious transformations in the Graeco-Roman Empire, Leiden, 2013, p. 17-40, at p. 35-39.

123. .SEG 46, 1519 (J.MA, Antiochos III and the Cities of Western Asia Minor, Oxford, 1999, p. 371, no. 49); on the cult cf. ibid., 1520; SEG 32, 1237; P. HERRMANN, "Mystenvereine in Sardeis", Chiron 26 (1996), p. 315-348, at p.318-321 (who refers to the Apollo Mystes of Daldi, Artemidorus, Onirocritica 2.70, p. 203 Pack). L. CAPDETREY, Le pouvoir séleucide: territoire, administration, finances d'un royaume hellénistique, 312-129 avant J.-C., Rennes, 2007, p. 171, supposes the cult to have been controlled by 'une famille sacerdotale indigène', which is not demonstrable: but the priest in question has a good Lydian name, Kadoas son of Pleri. Also probably late hellenistic, but unassignable to a cult, are a group of $\mu$ $\sigma \tau \alpha \_l$ at Teos, BCH 4 (1880), p. 164, no. 21.

124. The view that two 'no entry to non initiates' signs found in the excavations of the mystery sanctuary on Samothrace relate to particular buildings, not the whole precinct, has been strongly challenged: see most recently K. CLINTON, "Preliminary Initiation in the Eleusinian Mysteria", in A. MATthaiou, I. polinskaya (eds.), Mikros Hieromnemon. Meletes eis Mnemen Michael H.Jameson, Athens, 2008, p. 25-34, at p. 26-7. Isis: see BURKERT, o.c., (n. 120), p. 41. 
125. .S. MAYASSIS, Mystères et initiations dans la préhistoire et protohistoire, de l'Anté-Diluvien à SumerBabylone, Athens, 1961, appears to be an isolated voice.

126. 2.171.1. See BREMMER, o.c. (n. 115), p. 110-114, with references. The origins of Isiac mysteries are obscure: P. MARTZAVOU, "Priests and Priestly Roles in the Isiac Cults", in A. CHANIOTIS (ed.), Ritual Dynamics in the Ancient Mediterranean, Stuttgart, 2011, p. 61-84, at p. 73-76, tentatively looks to Delos in the $2^{\text {nd }} \mathrm{C} . \mathrm{BC}$.

127. .SEG 29, 1205 (P.A. HARLAND, Greco-Roman Associations, II, North Coast of the Black Sea, Asia Minor, Berlin, 2014, no. 120); cf. the overviews of debate in P. DEBORD, L'Asie mineure au IV siècle, Bordeaux, 1999, p. 367-374, and HARLAND, ibid., p. 207.

128. .Sabazius: all evidence is problematic: on Demosthenes' comic picture of Aeschines' youth, 18.259-260, see G. MARTIN, Divine Talk, Oxford, 2009, p. 104-112; on Christian authors E.N. LANE, Corpus Cultus Iovis Sabazii, III, Conclusions, Leiden, 1989, p. 59-60. In a late text from Ormeleis (E.N. LANE, Corpus Cultus Iovis Sabazii, II, The Other Monuments and Literary Evidence, Leiden, 1985,

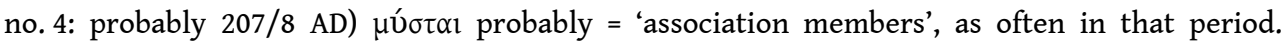
Angdistis: see above on the rites of Mother, her Greek name. Ma: see e.g. A. HARTMANN, RE XIV.1 (1928) s.v. "Ma", p. 86. Mysteries are not attested in the cult of Mên.

129. .So e.g. A.D. NOCK, Conversion, Oxford, 1933, p.60; M.P. NILSSON, Geschichte der griechischen Religion, II, Munich, $1961^{2}$ [1950], p.640, on the inscription N.VALmIN, "Inscriptions de la Messénie”, Bull. Soc. Royale des Lettres de Lund, 1928-1929, p. 123-124, no. 2, 1.19-24. Dea Syria's sanctuary at Thuria is already a place for document display a century earlier: VALMIN, l.c., 109-110, no. 1 .

130. .Le sanctuaire de la Déesse syrienne, Paris, 1985, p. 112 and 139.

131. This is 'widely acknowledged' according to LIGHTFOOT, o.c. (n. 86), p. 76.

132. .And even perhaps 'mouth-washing' (p. 229-230 above).

133. See Carbon, o.c. (n. 2), n. 12, for several possibly interconnected references to 'three days' in the text.

134. The opposite hierarchy would also be possible.

135. The effect of initiation could be spoken of as a purification, as in Plato, Phaedo, $69 \mathrm{c}$ quoted above (cf. Pl. Phaedrus, 250c; A. BERNABÉ, Poetae Epici Graeci II, Orphicorum ... Fragmenta, fasc. 2,

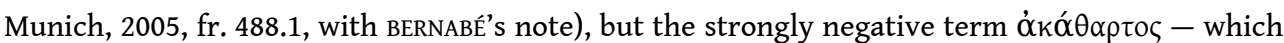
often means 'dirty villain' - was not normally applied to a non-initiate; note, however, $\mu \eta \theta \varepsilon ́ v \alpha$

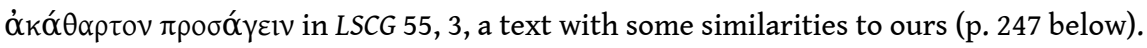

136. The term appears in a virulently anti-semitic account of the Jewish Exodus from Egypt in

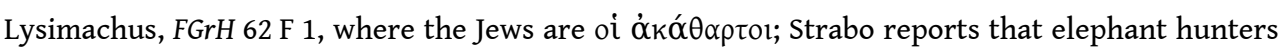

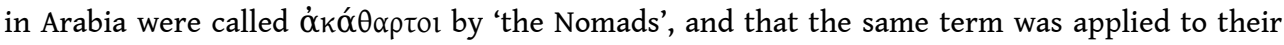
$\mu \alpha$ ó $\gamma \varepsilon$ po by the Troglodytes (Strabo, 16.4 .10 and 17). These reports can have no direct connection with our text.

137. .LIGHTFOOT, o.c. (n. 86), p. 517.

138. .For Egyptian priests see Hdt. 2.36.1; 2.37 .2 (whole body, every three days); Lucian, On Sacrifices, 14; Artemidorus, Onirocritica 1.22; for priests in Palmyra and Phoenicia H. SEYRIG, "Basreliefs monumentaux du temple de Bêl à Palmyre", Syria 15 (1934), p. 155-186, at p. 159; at Gades, Silius Italicus, 3.28.

139. .For Isis see Apuleius, Met. 11.10.1 (tunc influunt turbae sacris divinis initiatae, viri feminaeque omnis dignitatis et omnis aetatis linteae vestis candore puro luminosi, illae limpido tegmine crines madidos obvolutae, hi capillum derasi funditus verticem praenitentes); 11.28.5; 11.30.5; Martial 12.2.19; Juvenal 6.533; Plut. Is. et Os. $352 \mathrm{c}-\mathrm{d}$; Lactantius, Div. Inst. 1.21.20, deglabrato corpore; for a festival of Khnoum at Esna in the Ptolemaic period S. SAUNERON, Les fêtes religieuses d' Esna, Cairo, 1962, p. 344345 (translation); idem, Le temple d'Esna III, Cairo, 1968, no. 197 (hieroglyphic text); for the 
Egyptian Adonia G. GLoTz, “Les fêtes d'Adonis sous Ptolémée II", REG 33 (1920), p. 169- 222, at p. 182-184 (on P. Petr. 3.142).

140. .Lucian, Syr.D. 55; Macrobius, Sat. 1.23.13. For sacred barbers attached to Phoenician shrines see CIS I 86A, 1. 12 (Kition), ibid., 257-259, 588 (Carthage), with O. MASSON, M. SZNYCER, Recherches sur les Phéniciens à Chypre, Geneva, 1972, p. 50-51; cf. T.S.F. JIM, “Seized by the Nymph?”, Kernos 25 (2012), p. 9-26, at p. 19.

141. Carbon, however, has suggested to us that the propitiation might be needed for an imperfectly performed, not omitted, shaving. BREMMER, o.c. (n. 115), p. 139.

142. .The editors render $\sigma$ xoĩvos 'basket' ('corbeille'), though admitting that the reference is unknown: o.c. (n. 1), p. 45. бXoĩvo means 'rush, reed' or (LSJ II.1) 'anything twisted or plaited of rushes, esp. rope, cord': basket would then seem a possible meaning, but no instance is quoted. If it is a basket as the editors suppose, one might speculate that it served for collection of the shaven hair for some ritual purpose: the Nazirites in the Bible burn theirs on the altar (n. 145 below).

143. .Apuleius, Met. 11.10.1, quoted in n. 139.

144. .D. ARNAUD, Recherches au pays d'Aštata, Paris, 1986 (Emar VI, 3), no. 369, lines 7-28; English translation in W.W. HALLO and K.L. YOUNGER, The Context of Scripture, Leiden, 1996, p. 427-428; see also D.E. Fleming, The Installation of Baal's High Priestess at Ema, Atlanta, 1992, p.11 (text in transcription), 50 (translation), 181-182 (discussion of shaving).

145. Growing: Numbers 6:5, cf. Samson in Judges 13:5, 16:4-31; shaving: Numbers 6:18. For a discussion of ritual shaving in the bible, citing much comparative material, see S.M. OLYAN, Social Inequality in the World of the Text: The Significance of Ritual and Social Distinctions in the Hebrew Bible, Göttingen, 2011, p. 37-49.

146. .So LIGHTFOOT, o.c. (n. 86), note on Lucian, Syr.D. 6.

147. J. RUDHARDT, Notions fondamentales de la pensée religieuse et actes constitutifs du culte dans la Grèce classique, Paris, $1992^{2}$ [1958], p. 141. It appears in Xanthos' regulations for his cult of Mên (cf. p. 247 below), LSCG 55, 1. 12.

148. .Unless SEG 29, 1205 takes it back to Sardis in the 360s: on the dating of this text see n. 127.

149. .Aelius Aristides, 48.47.

150. See references in HERRMANN, o.c. (n. 123), p. 322, who is sceptical; this view is re-stated by M.F BASLEZ, "Les associations à Délos", in P. FRÖHLICH, P. HAMON (eds.), Groupes et associations dans les cités grecques, Geneva, 2013, p. 227-249, at p. 244-247.

151. See p. 220-221.

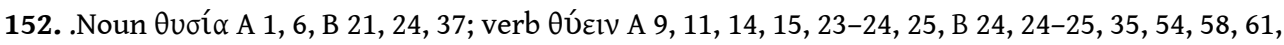
$75,76$.

153. For usage of $\theta u ́ \mu \alpha$ both on its own and in contrast with $\theta u \sigma i ́ \alpha$ see J. CASABONA, Recherches sur le vocabulaire des sacrifices en Grec, Aix-en-Provence, 1966, p. 146-152, who rightly emphasises that both terms occur in a wide variety of senses which are determined by the context in given cases. In our passage, as often elsewhere, $\theta$ ú $\alpha$ seems to mean 'offering' of any kind, animal or other, whereas $\theta v \sigma i ́ \alpha$ has its common connotation of human participation or festivity (ibid., p. 131-134), which is appropriate here, in contradistinction to $\theta \dot{v} \mu \alpha$, because the fowl are presumably to be eaten.

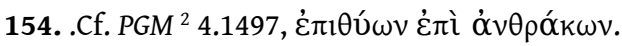

155. .IG XII 4 (1) 278 (LSCG 151 A, RHODES - OSBORNE, 62 A), 1.21-22, 36-37. E. KEARNS, "Cakes in Greek Sacrifice Regulations", in R. HÄGG (ed.), Ancient Greek Cult Practice from the Epigraphical Evidence, Stockholm, 1994 (ActAth-8 $\left.{ }^{\circ}, 13\right)$, p. 65-70, at p. 67 with n. 9 points to the term غं $\pi$ í $\pi \mu \mu \alpha$, "additional cake" in I.Priene [2014]), 146/147, 1. 15 (LSAM 38 B, 1. 10) of c. 200 BC, and 416 (LSAM

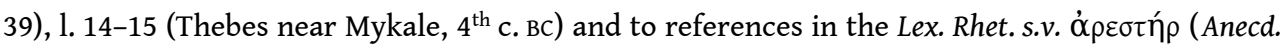




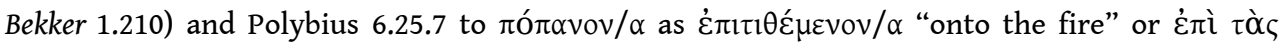
$\theta v \sigma i ́ \alpha \varsigma$ as indications that "accompanying offerings" of cake may have been standard procedure. 156. .IG XII 4 (1) 332 (LSCG 157) A, 1. 1-3.

157. .LSS 115 (RHODES - OSBORNE, 97) B, 1. 5-6 (87-88), 14 (96), 22-23 (104-105). In the earlier part of

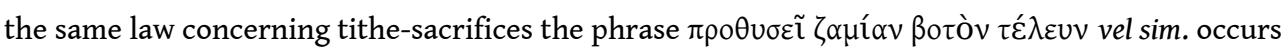

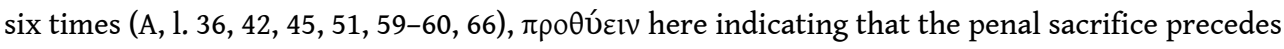
rather than follows the tithe-sacrifice (or in one case purification, A, 1.40-42) with which it is closely associated.

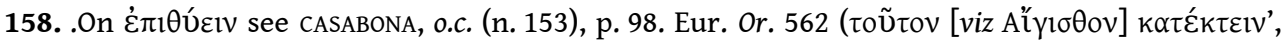
$\dot{\varepsilon} \pi \grave{l} \delta$ ' '̌ $\theta v \sigma \alpha \mu \eta \tau \dot{\varepsilon} \rho \alpha)$ is a good literary parallel for the 'associated sacrifice' sense in our passage, and the usage is precisely parallel to that of $\dot{\varepsilon} \pi 1 \rho \rho \varepsilon ́ \zeta \varepsilon ı v$ at LSCG 136, 1.27-29 (Ialysos, ca. 300 BC):

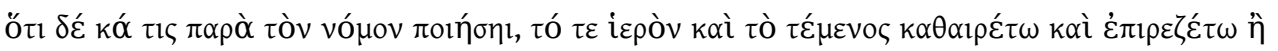

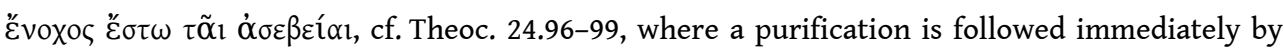

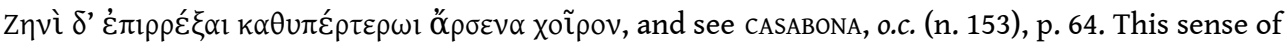
the preposition is also illustrated by the first $\dot{\varepsilon} \pi \grave{i}$ in the sentence that begins at Marmarini B 36-

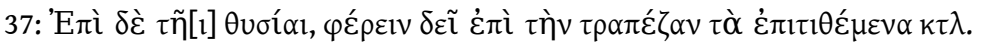

159. IC IV 146 (LSS 114).

160. .LSCG 76 (G. ROUGEMONT, Corpus des inscriptions de Delphes I, Paris, 1977, no. 3), 1. 2-5.

161. See e.g. CASABONA, o.c. (n. 153), p. 101-102; ROUGEMONT (previous note) 14-15; C.D. BUCK, “The Delphian Stadium Inscription", CP 7 (1912), p. 78-81, at p. 80; idem, The Greek Dialects, Chicago, 1955, p. 239; DECOURT - TZIAPHALIAS, o.c. (n. 1), p. 38-39. DECOURT and TZIAPHALIAS (p. 39, n. 83) accept, and adopt for our passage, the interpretation of HOMOLLE, BCH 23 (1899), p. 611, 'il recommencera son sacrifice', i.e. replace a previous, invalid offering with a second victim, but neither at Delphi nor in any of the cases in our text is there a preceding sacrifice which the sacrifice associated with the purification might be putting right.

162. .M.H. JAMESON, D.R. JORDAN, R.D. KOTANSKY, A Lex Sacra from Selinous, Durham, 1993 (GRB Monographs, 11) = SEG 43, 630 = NGSL 27 (Selinous, Sicily, ca. 470-450 BC?), B, 1. 3-9, 10-11.

163. .Cf. R. PARKER, Miasma: Pollution and Purification in Early Greek Religion, Oxford, 1983, p. 10: “In theory sacrifice and purification may seem to be distinct operations ... In practice, what is spoken of as a purification often takes the form of a sacrifice".

164. .CASABONA, o.c. (n. 153), p. 95-96, at 95.

165. These two forms of "cake", neither hitherto known in a sacred law, appear repeatedly in the text. In B 37, 58 and 68 it is specified that they are for the offering table. A "choinix of $\lambda \alpha$ ' $\gamma \alpha v \alpha$ " presumably means "the quantity of $\lambda \alpha{ }^{\prime} \gamma \alpha v \alpha$ that can be made from a choinix of wheat":

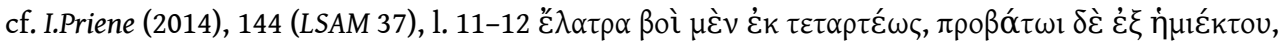

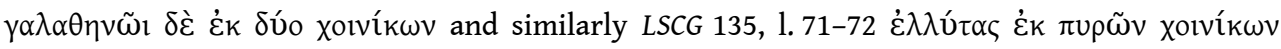

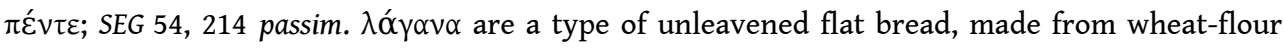

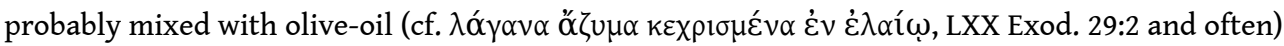
and fried in a frying pan: see references in S.D. OLSON and A. SENS, Matro of Pitane and the Tradition of Epic Parody in the Fourth Century BCE, Atlanta, Georgia, 1999, p. 149, and for the type of cake E. KEARNS, “ 'O $\lambda_{1} \beta \alpha v \omega \tau$ ¿̀ Greek sacrifice”, in V. PIRENNE-DELFORGE, F. PRESCENDI (eds.), Nourrir les dieux, Liège, 2011, p. 89-104, at p. 91; the plural suggests they may have been small. ö $\mu \rho \rho \alpha$ is new, but the editors adduce

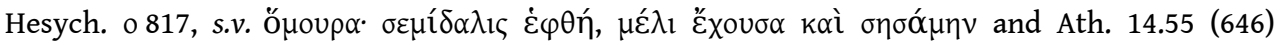

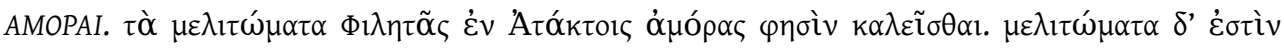
$\pi \varepsilon \pi \varepsilon \mu \mu \varepsilon \dot{\varepsilon} \nu \alpha$.

166. Innards are common priestly perquisites: LSS 129 , 1. 1-4 (Chios, $5^{\text {th }} \mathrm{C}$. BC, priesthood of a god with the epithet Pelinaios): priest to receive $\sigma \pi \lambda \alpha^{\prime} \gamma \chi v \alpha \alpha$;SCG $60,1.15-17$ (Epidaurus, late $5^{\text {th }}$ C. BC): 


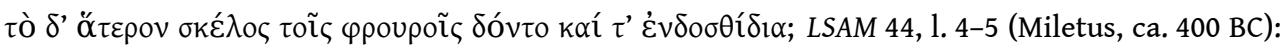
$\sigma \pi[\lambda \alpha]_{\gamma \chi \alpha} \alpha \alpha$ among priestly perquisites; LSS 77, 1.6 (Chios, early $4^{\text {th }} \mathrm{C} . \mathrm{BC}$ ): priest to receive $\sigma \pi \lambda \alpha \gamma_{\gamma \chi \chi} \alpha$; LSCG 119, 1. 1-4, 6-8 (Chios, $4^{\text {th }}$ C. BC): priest of Heracles to receive $\sigma \pi \lambda \alpha \alpha^{\prime} \gamma \chi \alpha \alpha ; L S C G 120$ (Chios, $4^{\text {th }}$ C. BC), based entirely on (plausible) restorations; LSAM 24 A, 1. 13-25 (Erythrai, 380-360

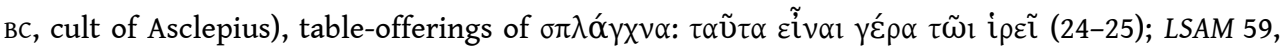
1. 1-3 (Iasos, $4^{\text {th }}$ C. BC), perquisites of priest of Zeus Megistos include $\sigma \pi \lambda[\alpha ́ \gamma \chi \nu \omega v] \tau \varepsilon ́ \tau \alpha \rho \tau o \mu \mu \varepsilon^{\prime} \rho \circ$; LSAM 72, 1.39 (Halicarnassus, $3^{\mathrm{rd}} \mathrm{c} . \mathrm{BC}$, foundation of Posidonius), priest to receive $\tau \varepsilon \tau \alpha \rho \tau \eta[\mu o] \rho i ́ \delta \alpha \sigma \pi \lambda \alpha \gamma_{\gamma \chi \nu \omega v}$;SAM 73, 1.11-12, 14 (Halicarnassus, $3^{\text {rd }}$ c. BC, sale of priesthood of

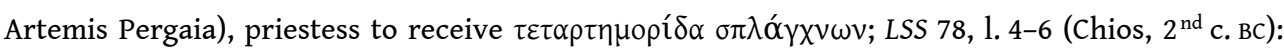
priest to receive $\sigma \pi \lambda \alpha^{\prime} \gamma \chi \chi v \alpha$; cf. $L S C G$ 125, 1.4 (Mytilene, $2^{\text {nd }}$ c. BC): some portion of $\sigma \pi \lambda \alpha^{\prime} \gamma \chi \chi \alpha \alpha$ as a table-offering. Possibly, but very uncertainly, SEG 33, 456 = NGSL 11, 1.24, with LUPU's note ad loc. (p. 236-237).

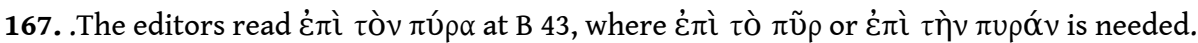

168. .DECOURT - TZIAPHALIAS, o.c. (n. 1), p. 31 quote Paus. 1.24. 2, who describes a statue of Phrixus

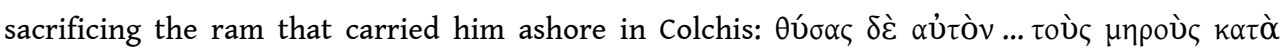

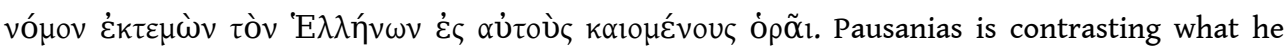
knows to be standard Greek sacrificial procedure - the cutting out and burning of the thighbones (cf. Gunnel ЕКROTH, "Thighs or tails? The osteological evidence as a source for Greek ritual norms", in P. BRULÉ (ed.), La norme en matière religieuse en Grèce ancienne, Liège, 2009 (Kernos, suppl. 21), p. 125-151, at 127 with n. 5) - with whatever he imagined to be Colchian practice, or

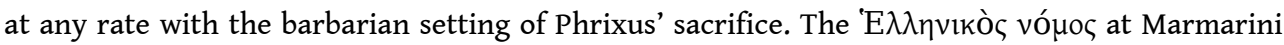
has removal and burning in common with the norm reflected in Pausanias' phrase "in accord with the custom of the Greeks", but, in contrast to the commonest Greek practice, requires that very much more than the thighbones be removed and burnt.

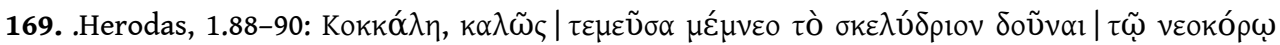

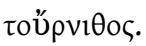

170. .As between "Greek Rite" victims and bovines there are also increases in most of the other accompanying offerings for the larger animal: for Greek rite victims one choinix of $\lambda \alpha$ ' $\gamma \alpha v \alpha$, one choinix of ö $\mu \rho \rho \alpha$, one kotyle of oil for the lamp, and one chous of wine are prescribed, but for bovines three choinikes of $\lambda \alpha{ }^{\prime} \gamma \alpha v \alpha$, the same single choinix of ö $\mu \rho \rho \alpha$, two choes of wine, and two kotylai of oil (not specified as "for the lamp"), as well as "sufficient wood".

171. .CASABONA, o.c. (n. 153), p. 35-36.

172. .See S. SCULlion, "Heroic and Chthonian Sacrifice: New Evidence from Selinous", ZPE 132 (2000), p. 163-171, especially p. 165.

173. .LSCG 63, 1. 4-5; IG XII Suppl. 353, 1.10; LSCG 96, 1. 23-24; SEG 43, 630 = NGSL 27, A, 1.11-12; SCULLION (previous note) discusses all these passages.

174. .Leaving aside, that is, prescriptions of holocaust for particular recipients in sacrificial calendars, which may tell us no more than that a holocaust was the mode employed in the customary sacrifice offered by a public body or cultic group on that particular occasion.

175. .For "dining areas" see G. EKROTH, "Meat in Ancient Greece: Sacrificial, Sacred or Secular?", Food and History 5 (2007), p. 249-272, at p. 260-263; ead., "Meat, Man and God: On the Division of the Animal Victim at Greek Sacrifices", in MATTHAIOU - POLINSKAYA (eds.), o.c. (n. 124), p. 259-290, at p. 280-281; or eadem, "Bare Bones: Osteology and Greek Sacrificial Ritual", forthcoming in I. RUTHERFORD (ed.), Animal Sacrifice in the Ancient World, Cambridge.

176. .DECOURT - TZIAPHALIAS, o.c. (n. 1), p. 43.

177. .LSCG 55, 1. 20.

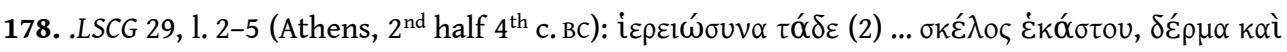

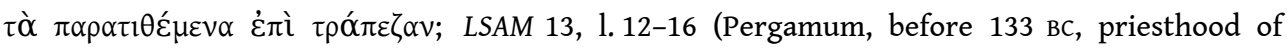




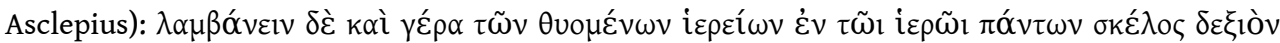

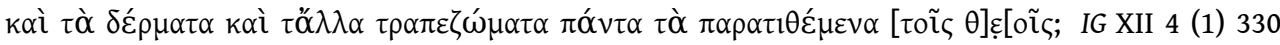

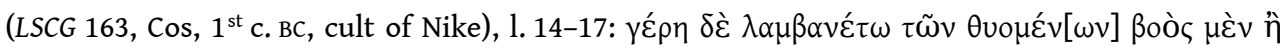

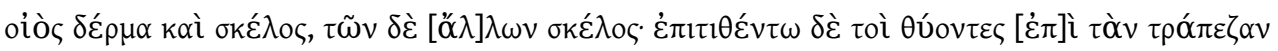

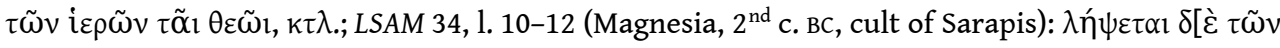

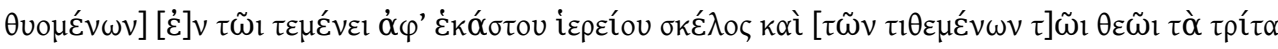

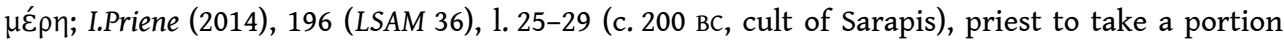
(text uncertain) of table-offerings; IG XII 4 (1) 326 (LSCG 166, Cos, $1^{\text {st }}$ c. BC, cult of Dionysus Thyllophorus), 1. 62-66 relies on plausible restorations; LSCG 103 B, 1. 5-10 (Minoa on Amorgos, $1^{\text {st }}$

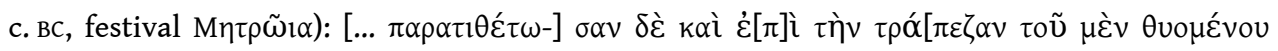

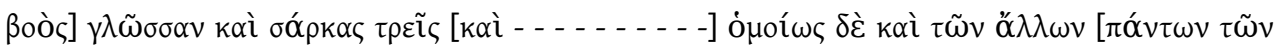

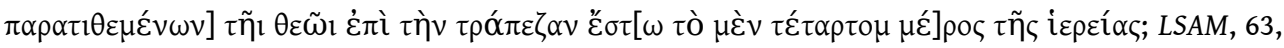
1. 7-8 (dubious restoration). A new inscription from late-iii-BC Iasos entitles the purchaser of the priestesshood of Mother of the Gods to take from the sanctuary table everything offered by

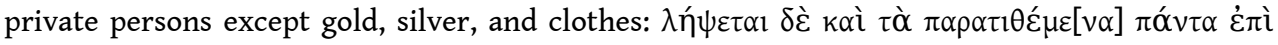

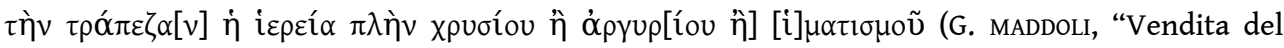
sacerdozio della Madre degli Dei", SCO 61.2 [2015], p. 101-118, at p. 103, 1. 16-18).

179. .Ath. 3.110.

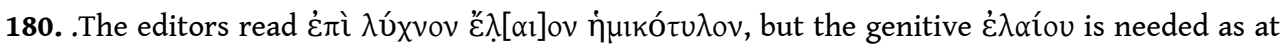
A 36 , B 11, 38, 48, 57, 59, 69-70, 72, and though we cannot read that word on the photograph we

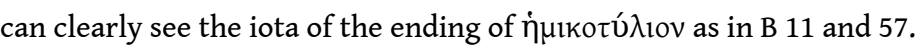

181. .DECOURT - TZIAPHAliAs, o.c. (n. 1), p. 43; Rhesus, 361-362. There is a good note ad loc. on $\pi \alpha v \eta \mu \varepsilon \rho \varepsilon u ́ \varepsilon I v$ and its cognates in A. FRIES, Pseudo-Euripides, Rhesus, Berlin, 2014, p. 252-253.

182. .Eleusis: IG II $^{2} 1363$ = LSCG 7, 1. 3-7; Piraeus: IG II ${ }^{2} 1283$ = LSCG 46, 1. 19; Thorikos: SEG 33, 147 = NGSL 1, 1. 3-4, 16; Sparta: IG V 1, 363 = LSCG 62, 1. 7, 10; Miletus: LSAM 50, 1. 45.

183. For the eating of unsacrificed meat see R. PARKER, "Eating Unsacrificed Meat", in P. CARLIER, C. LEROUGE-COHEN (eds.), Paysage et religion: mélanges offerts à Madeleine Jost, Paris, 2010 (Travaux de la maison René-Ginouvès), p.139-147; S. scullion, "Bones in Greek Sanctuaries: Answers and Questions", in G. ЕКRоTH, J. WALLENSTEN (eds.), Bones, Behaviour and Belief, Stockholm, 2013 (ActaAth$\left.4^{\circ}, 55\right)$, p. 243-55, at p. 246-253; F.S. NAIDEN, Smoke Signals for the Gods: Ancient Greek Sacrifice from the Archaic through Roman Periods, New York, 2013, p. 232-275.

184. The distinction is perhaps clearest and most explicit in one of our most careful and detailed descriptions of sacrificial procedures, the mid- $4^{\text {th }}-\mathrm{C}$.-BC Coan sacrificial calendar, where at IG XII 4 (1) 278, 1. 48-49 (LSCG $151 \mathrm{~A}$ and RHODES - OSBORNE, 62 A, 1. 47-48) food offerings that are burnt are

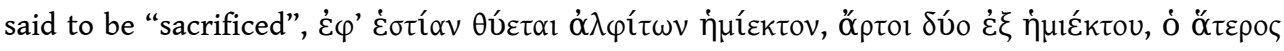

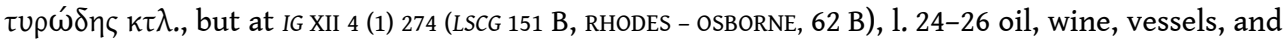

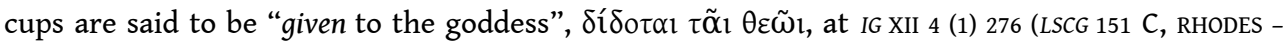

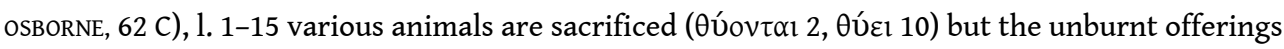
of grains, tableware, honey, cheese, a stove, wine and wood that accompany them are spoken of

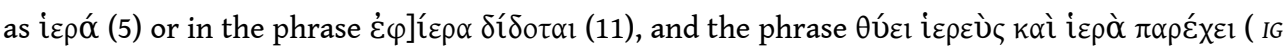
XII 4 [1] 278, 1. 59) vel sim. recurs constantly (A 46-47, 57, 62, 63-64, ibid., 274, 1. 3, and passim).

185. .See e.g. CASABONA, o.c. (n. 153), p. 72-75; J.-P. VERNANT in M. DETIENNE, J.-P. VERNANT, La cuisine du sacrifice en pays grec, Paris, 1979, p. 45 = P. WISSING, transl., The Cuisine of Sacrifice among the Greeks, Chicago, 1989, p. 26; RUDHARDT, o.c. (n. 147), p. 263-264, 321.

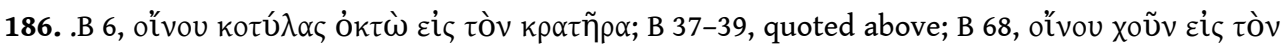

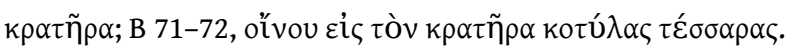

187. DECOURT - TZIAPHALIAS, o.c. (n. 1), p. 41.

188. .See ABUSCH, o.c. (n. 96). 
189. .E.g. SEG 28, $421=$ NGSL 7, 1. 4-5 (Megalopolis, ca. 200 BC); SEG 28, $750=$ NGSL 24, 1.3 (Lissos in Crete, Hellenistic or Roman).

190. .LSCG 114 A, 1. 1-2; LSCG 126. There is more restricted "supplementary" choice at SEG 35, 113, 1. 14 = NGSL 3, 1.14 (Phrearrhioi in Attica, ca. 300-250 BC), which apparently allows those wishing

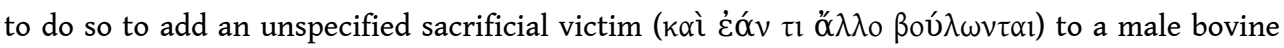
and another victim (lost in a lacuna) prescribed for Kore.

191. .LSCG 69, 1. 30-31.

192. .Paus. 9.19.7.

193. See p. 262 below.

194. .Trubba is a previously unattested type of bird: see DECOURT - TZIAPHALIAS, o.c. (n. 1), p. 40.

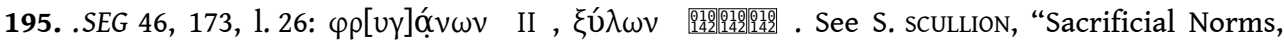
Greek and Semitic: Holocausts and Hides in a Sacred Law of Aixone”, in BRULÉ (ed.), o.c. (n. 168), p. 153-169.

196. .See DECOURT - TZIAPHALIAS, o.c. (n. 1), p. 41-42.

197. .On the requirement see S. ScULLION, "Olympian and Chthonian", ClAnt 13 (1994), p. 75-119, at p. 98-112. For the phrase, SEG 35, 923, 1. 4-12 = NGSL 20, 1. 6-10; LSS 94, 1. 12-14; LSAM 34, 1. 7; Paus. 8.38.8; for the verb in the same sense see Paus. 2.27.1.

198. .DECOURT - TZIAPHALIAS, o.c. (n. 1), p. 20, cf. p. 31, n. 50.

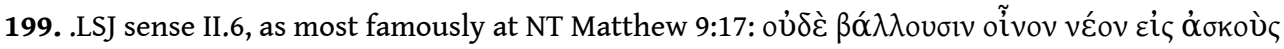
$\pi \alpha \lambda \alpha$ เoú $\varsigma$, "nor pour new wine into old wineskins".

200. .For pure water and saltwater as purifying agents see especially PARKER, o.c. (n. 163), p. 226-

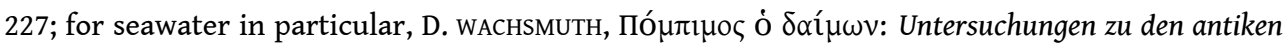
Sakralhandlungen bei Seereisen, diss. Berlin, 1967, p. 219-223.

201. .Sophron, fr. 4, 2-4 in R. KASSEL, C. Austin, Poetae Comici Graeci I, Berlin, 2001, p. 194 and in J. HORDERN, Sophron's Mimes, Oxford, 2004, p. 42: a lump of salt is taken in the hand and laurel put by the ears; Clem. Alex. Strom. 7.4. 26. 2-3 (vol. III, p. 19 STÄHLIN-FRÜCHTEL): lumps of salt are listed alongside red wool, torches, squill, and sulphur; $\Sigma$ Aristoph. Nub. 1237: the mentally disturbed soaked with salt and oil; see PARKER, o.c. (n. 163), p. 227, n. 109; Menander, Phasma, 54-56 (ed.

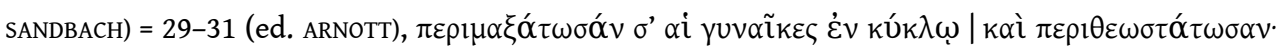

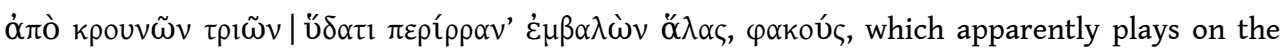
making of soup.

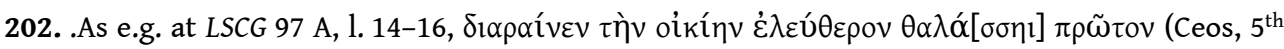

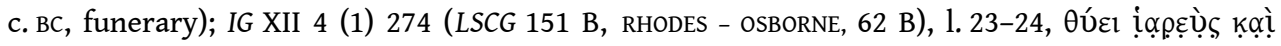

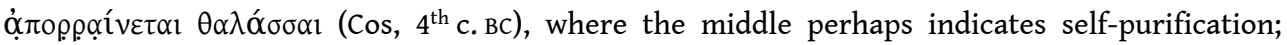

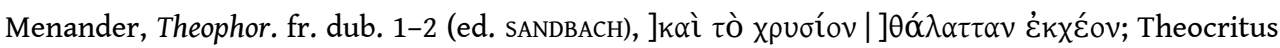

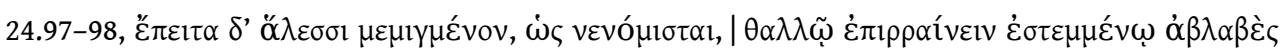
vँ $\delta \rho \rho$, "and then, as the custom is, sprinkle pure water mixed with salt, using a twig wound with

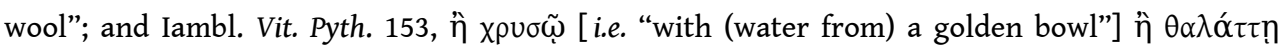

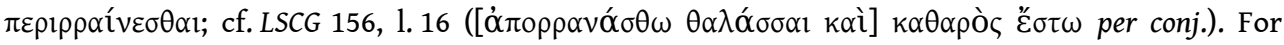
aspersion see esp. JAMESON, JORDAN, KOTANSKY, o.c. (n. 162), on lines B 11 (p. 45) and A 12f. (p. 33).

203. See p. 247-249.

204. .On providing kosmos for cult statues see e.g. Hyperides, Euxenippos, 24-26; IG II $^{3} 445$.

205. See p. 241-242.

206. .Hesychius $\varphi 681$ (ed. HANSEN-CUNNINGHAM), $\varphi$ oı o.c. (n. 1), p. 34 .

207. .LSCG 39, 1. 24-26; 58, 1. 12-14. 


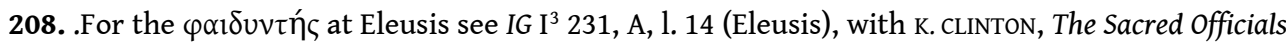

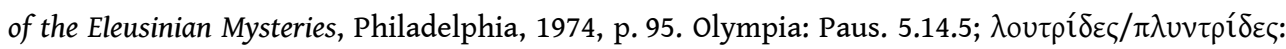

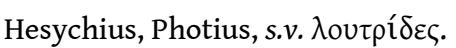

209. Conceivably the masculine is broadening the regulation to include men who have not been purified from contact with women in the preceding conditions as well the women themselves. But, unclarity aside, no Greek sacred law speaks of men being contaminated by contact with a menstruating woman.

210. .PARKER, o.c. (n. 163), p. 52, n. 74.

211. .NGSL 7, 1. 6-9.

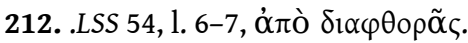

213. .LSS 11, 1. 10, ’’ $\pi^{\prime} \dot{\varepsilon} \kappa \tau \rho \omega \sigma \mu о \tilde{v}$.

214. .LSCG 124, 1. 5-6, ? $2^{\text {nd }} c$. BC.

215. .See PARKER, o.c. (n. 163), p. 50, n. 67 and p. 355-356 (with some later evidence), where it is argued that these regulations do not distinguish natural from procured abortion.

216. .NGSL 7, 1. 8-9 (7 days); LSS 54, 1. 7-8 (9 days); LSS 119, 1.13 (7 days).

217. .LSS 55, 1.5 (7 days).

218. See PARKER, o.c. (n. 163), p. 102, n. 112. For menstrual pollution in a confession inscription

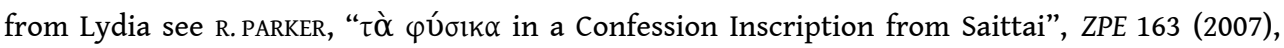
p. 121-122.

219. . NGSL 7, 1. 12-13.

220. .LSJ s.v. $\dot{\alpha} \pi$ ó, III 6.

221. IG XII 4, 72 (LSCG, 154) passim. Cf. n. 228 below.

222. .But note that the Alouliastai discovered by Carbon (p. 212 above) are on Cos.

223. .LSCG 94, from Delos; Apuleius, Metamorphoses 11.23.2; Plut. Is. et Os. 353 a-c.

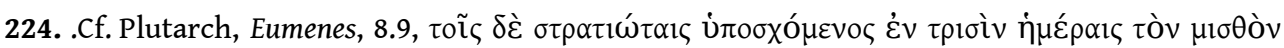

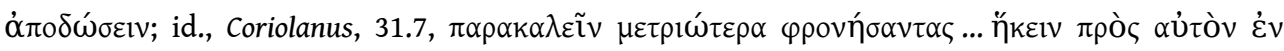

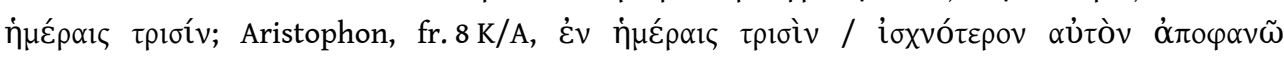
$\Phi 1 \lambda \imath \pi \pi i ́ \delta o v ;$ LSJ s.v. $\dot{\varepsilon} v$, IV 2.

225. Plutarch, l.c. (n. 223), with the commentary of J. GWYN GRIFFITHS, University of Wales Press, 1970, ad loc.

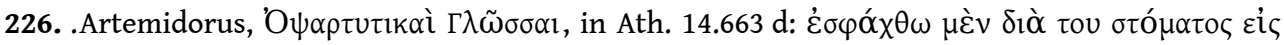

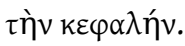

227. ' $\delta 1 \alpha \kappa \lambda \hat{\zeta} \zeta \omega$ belongs to a rare formal group of verbs alongside $\beta \lambda \hat{\zeta} \zeta \omega$ and $\varphi \lambda \hat{\jmath} \zeta \omega$, but the latter too mean "bubble up, gush forth" and "boil over, bubble up", respectively: so they are clearly intransitive (though active in form). With such "parallels" in place, transitive $\delta 1 \alpha \kappa \lambda \hat{u} \zeta \omega$ "wash out" could seem the odd one out and hence in need of clearer marking of its factitivecausative (transitive) value. For that purpose, the productive factitive-causative suffix - $\alpha$ ív $\omega$ was quite suitable, all the more, perhaps, because - $\alpha$ ív $\omega$ did occur with u-stem-based adjectives,

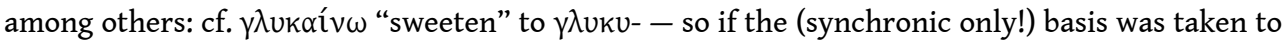
be $\delta 1 \alpha k \lambda v^{-}$, then $\delta 1 \alpha k \lambda \alpha i ́ v \omega$ would seem a reasonably straightforward neo-formation.' But he

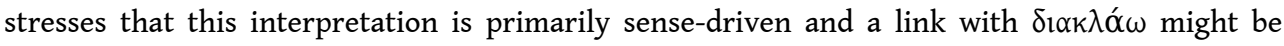
easier formally.

228. .See JAMESON, JORDAN, KOTANSKY, o.c. (n. 162), p. 33 on the Coan ó

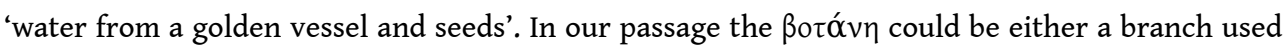
for sprinkling, or some leaves that are thrown.

229. .For possible Mesopotamian antecedents that might help to explain this development see p. 229-230 above.

230. .NGSL 7, 1.10-11; LSS 54, 1.2-3; cf. PARKER, o.c. (n. 163), p. 359, n. 12, LUPU's note on NGSL 7, 1. 10-12. 
231. .Aeschylus, fr. 168, 16-17 (ed. RADT); Hdt. 4.35.3; cf. P. DEBORD, Aspects sociaux et économiques de la vie religieuse dans l'Anatolie gréco-romaine, Leiden, 1982, p. 196; H.U. WIEMER, D. KAH, "Die Phrygische Mutter im hellenistischen Priene", EA 44 (2011), p. 1-54, at p. 9.

232. .Above, p. 218-220. But for parallels to many of them in Greco-Egyptian cults see the index

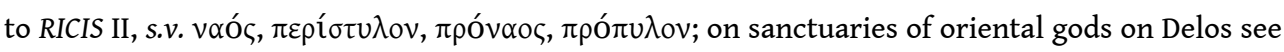
P. BRUNEAU, Recherches sur les cultes de Délos à l'époque hellénistique et à l'époque impériale, Paris, 1970, p. 457-480.

233. .See CARBON, o.c. (n. 2), p. 195, n. 20.

234. .See COHEN, o.c. (n. 12), p. 104, 389-407. Akitu rituals were celebrated for various gods and goddesses. For Assyrian Astrolabe B's characterisation of the month Elulu as that when 'the goddesses purify themselves in the sacred river' see ibid., p. 422 . Note too n. 105 above. But on washing of statues in rivers or the sea in Greek cult see e.g. PARKER, o.c. (n. 163), p. 27-28. On rites in Nisan see n. 12 above. It has been suggested to us that the unpredictable "coming of the goddess from the river' might refer to the unpredictable appearance of the first new moon of the new year. But we struggle to understand 'from the river' on this view.

235. .See Carbon, o.c (n. 2), n. 195, n. 19.

236. .Semitic: the festival names; 'Pan whom the Syrians call [...] PLEN'. Anatolian: Mên. Mên is unattested in Syria with the single exception of his appearance on coins of Laodicea ad Libanum from the time of Hadrian onwards: see E. LANE, Corpus Monumentorum Religionis Dei Menis, vol.2, Leiden, 1975, p. 162-163; the map at the end of the volume shows the extreme isolation of this attestation.

237. .Anabasis 1.4.9. Cf. for fish LIGHTFOOT, o.c. (n. 86), p. 65-72, beginning: 'if there was one thing that characterized the Syrian goddess in Greek eyes, it was her association with fish'; for doves, where the evidence relates predominantly though not exclusively to Syria, see ibid., p. 513.

238. .R. STRÖMBERG, Studien zur Etymologie und Bildung der griechischen Fischnamen, Göteborg, 1943, p. 89.

239. .LSCG 39, 1. 24.

240. o.c. (n. 1), p. 34 .

241. .V. PIRENNE-DELFORGE, L'Aphrodite grecque, Liège, 1994, p. 396-392; Thasos: LSCG 114; LSS 73. On the widespread ban among Near Eastern peoples see references in LIGHTFOOT, o.c. (n. 86), p. 512, n. 1.

242. .As acutely observed by CARBON, o.c. (n. 2), p. 204. Painted gravestones: A.S. ARVANITOPOULlOS,

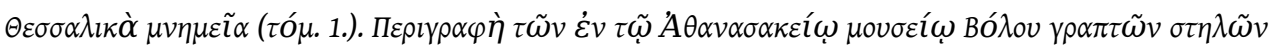

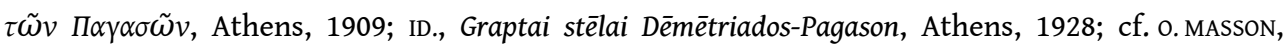
"Épitaphes de Phéniciens à Démétrias de Thessalie", BCH 93 (1969), p. 687-700. Among the many slave names attested in Thessaly by manumission inscriptions (R. ZELNICK-ABRAMOWITZ, Taxing Freedom in Thessalian Manumission Inscriptions, Leiden, 2013, p. 151-156), names such as $\Sigma$ úpa/o occur (e.g. IG IX 2, 287 b, 1. 7; 474, 1.34-35), but not with significant frequency. For a stray 'Chaldaian astronomer' from Hierapolis who had acquired citizenship in Homolion see SEG 31, 576.

243. Syll. ${ }^{3} 543$.

244. .D.P. THEOCHARIS, AD 17 B (1961/62), p. 179, no. 4b, drawn to our attention by Sofia Kravaritou. 245. . Y. BÉQUIGNON, Recherches archéologiques à Phères de Thessalie, Paris, 1937, p.91, no. 64. Parthenos: cf. R. PARKER, "Theonyms in Northern Greece”, forthcoming in C. ANTONETTI, A.M. GUIMIER-

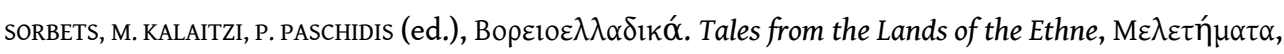
Athens, 2017(?).

246. .See n. 256 below.

247. .6.533.

248. .See p. 260 above. 
249. .For useful selections see Greco-Roman Associations: Texts, Translations and Commentary, I, J.S. KLopPenborg, R.S. Ascough, Attica, Central Greece, Macedonia, Thrace, Berlin, 2011; II, P.A. HARLAND, North Coast of the Black Sea, Asia Minor, Berlin, 2014.

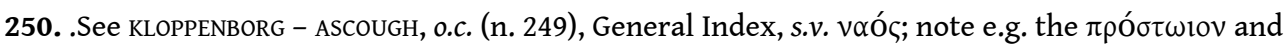
óé $\tau \omega \mu \alpha$ of $I G \mathrm{II}^{2} 1271$ (their no. 13).

251. .E.g. Adonia, IG II ${ }^{2} 1261$ (KLOPPENBORg and ASCOUGH, o.c. [n. 249], no. 9), 1. 9; 'both the Attideia', IG II 1315 (KLOPPENBORG - ASCOUGH, no. 29), 1. 10.

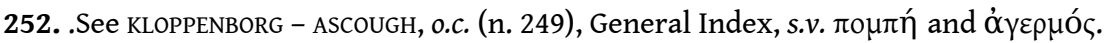

253. .IG II ${ }^{2} 1361$ (KLOPPENBORG - ASCOUGH, o.c. [n. 249], no. 4), 1. 4-5; cf. R. PARKER, Athenian Religion, Oxford, 1996, p. 170-1. KLOPPENBORG and ASCOUGH, p. 166, are wrong to identify the sanctuary of Dionysus in the Piraeus at which ephebes sacrificed with that of the Dionysiasts; the cult of Dionysus in the Piraeus long antedated the association (e.g. IG II $\left.^{2} 1496,1.70,144\right)$.

254. .IG II 337 (KLOPPENBORG - ASCOUGH, o.c. [n. 249], no. 3); IG XI 4, 1299.

255. .Thessalonike: RICIS 113/0501-2; Delos: BRUNEAU, o.c. (n. 232), p. 462; Athens: IG II ${ }^{2} 4692$ (RICIS 101/0202), as interpreted by s. Dow, “The Egyptian Cults in Athens", HThR 30 (1937), p. 184-232, at p. 198-201 (dating it c. 200; the new dedication SEG 59, 274 may still relate to a private cult); Demetrias: RICIS 112/0702-4; Priene: I.Priene (2014), 196 (RICIS 304/0802; LSAM 36); Magnesia: RICIS 304/0701 (LSAM 34). Manumissions: RICIS 105/0602 with note; cf.e.g. RICIS 105/0201 (Sarapieia in Tanagra, c. 90-85 BC); RICIS 112/0503 (a dedication by the polis of Larisa to Harpocrates, ? $1^{\text {st }}$ c. BC).

256. Delos: BRUNEAU, o.c. (n. 232), p. 468; Thuria: note 129 above; Beroia: L.gounARopoulou,

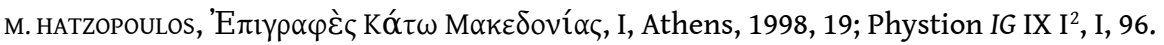

257. .On all this see BRUNEAU, o.c. (n. 232), p. 457-473; on the Sarapieia now I. MOYER, Egypt and the Limits of Hellenism, Cambridge, 2011, p. 142-207.

258. .P. RousSEL, Délos, colonie athénienne, Paris, 1916, p. 251.

259. .These points were made to one of us by, respectively, Sylvie Honigman and Miltiades Hatzopoulos.

\section{ABSTRACTS}

This paper re-visits in detail the problems raised by the text from Marmarini published in Kernos 2015. We accept J.M. Carbon's calendrical location (Kernos 2016) of the festivals mentioned in it (Nisanaia, Eloulaia) that derive from month names of the standard Mesopotamian calendar. We discuss: the possible contents of the lost sections; the gods mentioned (we dissociate the patron goddess of the sanctuary from Artemis Phylake); the physical form of the sanctuary (indeterminable in detail); possible Near Eastern ritual influences; the initiations/mysteries of the text in relation to other Hellenistic mysteries; sacrificial terms and procedures, with particular attention to the complex sacrificial vocabulary of the text, sacrifice by 'the Greek rite', and the apparent recycling of sacrificial meat within the sanctuary; purity, purifications and abstentions; the general character of the text, which we tentatively suggest may have been issued by a city which had incorporated an imported cult.

Le présent article se penche sur le détail des problèmes soulevés par le texte de Marmarini publié dans Kernos 2015. Nous acceptons le placement calendaire des fêtes qui y sont mentionnées 
(Nisanaia, Eloulaia) tel que l'a proposé J.-M. Carbon (Kernos 2016) : elles dérivent de noms de mois du calendrier mésopotamien standard. Voici les points que nous discutons : le contenu éventuel des sections perdues ; les dieux mentionnés (nous dissocions la déesse patronne du sanctuaire de l'Artémis Phylakè); l'apparence du sanctuaire (indéfinissable dans le détail); de possibles influences rituelles proche-orientales ; les initiations/mystères du texte en relation avec d'autres mystères de la période hellénistique ; les termes et les procédures sacrificiels, avec une attention toute particulière au vocabulaire sacrificiel complexe utilisé dans le texte, au sacrifice «à la manière grecque ", et au recyclage apparent de la viande sacrificielle dans le sanctuaire; la pureté, les purifications et les obligations d'abstinence; le caractère général du texte, dont nous faisons l'hypothèse qu'il pourrait avoir été émis par une cité qui avait intégré un culte importé.

\section{AUTHORS}

\section{ROBERT PARKER}

New College

Oxford, OX1 3BN

robert.parker@new.ox.ac.uk

SCOTT SCULLION

Worcester College

Oxford, OX1 2HB

scott.scullion@worc.ox.ac.uk 